\title{
Thermal Modeling of
}

NUHOMS HSM-15 and HSM-1

Storage Modules at Calvert Cliffs Nuclear Power Station ISFSI

SR Suffield

JA Fort

HE Adkins
JM Cuta

BA Collins

ER Siciliano

October 2012

Pacific Northwest

NATIONAL LABORATORY

Proudly Operated by Battelle Since 1965 


\title{
DISCLAIMER
}

This report was prepared as an account of work sponsored by an agency of the United States Government. Neither the United States Government nor any agency thereof, nor Battelle Memorial Institute, nor any of their employees, makes any warranty, express or implied, or assumes any legal liability or responsibility for the accuracy, completeness, or usefulness of any information, apparatus, product, or process disclosed, or represents that its use would not infringe privately owned rights. Reference herein to any specific commercial product, process, or service by trade name, trademark, manufacturer, or otherwise does not necessarily constitute or imply its endorsement, recommendation, or favoring by the United States Government or any agency thereof, or Battelle Memorial Institute. The views and opinions of authors expressed herein do not necessarily state or reflect those of the United States Government or any agency thereof.

\author{
PACIFIC NORTHWEST NATIONAL LABORATORY \\ operated by \\ BATTELLE \\ for the \\ UNITED STATES DEPARTMENT OF ENERGY \\ under Contract DE-AC05-76RL01830
}

Printed in the United States of America
Available to DOE and DOE contractors from the Office of Scientific and Technical Information,
P.O. Box 62, Oak Ridge, TN 37831-0062;
ph: (865) 576-8401
fax: $(865) 576-5728$
email: reports@adonis.osti.gov
Available to the public from the National Technical Information Service 5301 Shawnee Rd., Alexandria, VA 22312 ph: (800) 553-NTIS (6847)
email: orders@ntis.gov $<$ http://www.ntis.gov/about/form.aspx>
Online ordering: http://www.ntis.gov

This document was printed on recycled paper. 


\title{
Thermal Modeling of
}

NUHOMS HSM-15 and HSM-1

Storage Modules at Calvert Cliffs

Nuclear Power Station ISFSI

\author{
SR Suffield \\ JM Cuta \\ JA Fort \\ BA Collins \\ HE Adkins \\ ER Siciliano
}

October 2012

Prepared for

the U.S. Department of Energy

under Contract DE-AC05-76RL01830

Pacific Northwest National Laboratory

Richland, Washington 99352 



\section{Summary}

This report fulfills the M3 milestone M3FT-12PN0810041, "Report on Realistic Temperature Profiles", under Work Package FT-12PN081004.

As part of the Used Fuel Disposition Campaign of the Department of Energy (DOE), visual inspections and temperature measurements were performed on two storage modules in the Calvert Cliffs Nuclear Power Station's Independent Spent Fuel Storage Installation (ISFSI). The inspection procedure included surface temperature measurements on one end of the DSC within the storage module. The data obtained in the inspections at Calvert Cliffs provide an opportunity to develop structural and thermal models that can yield realistic temperature predictions for actual storage systems, in contrast to conservative and bounding design basis calculations.

Detailed models of the concrete storage modules to be examined were developed using STAR-CCM+ (version 7.02; CD-Adapco, 2012). The immediate purpose of this modeling effort is to obtain temperature predictions in actual storage conditions for the module, DSC, and DSC contents, including preliminary estimates of fuel cladding temperatures for the SNF. The long-term goal of this work is to obtain realistic evaluations of thermal performance of actual SNF storage systems over extended periods, which will require developing a detailed COBRA-SFS (Michener, et al., 1987) model of the DSC internals, in addition to the large system models. The approach used in this study omits many of the conservatisms and bounding assumptions normally used in design-basis and safety-basis calculations for spent fuel storage systems. The results of this study cannot be used in licensing basis evaluations of the Calvert Cliffs ISFSI, or any other spent fuel storage facility.

The storage modules used for this study are HSM-1 and HSM-15 in the Calvert Cliffs Nuclear Power Station's ISFSI, each containing a 24P DSC loaded with 24 CE $14 \times 14$ spent fuel assemblies. The total decay heat load for the DSC in HSM-15 was $10.8 \mathrm{~kW}$ at the time of loading, and was calculated to be 7.6 $\mathrm{kW}$ as of June 2012. The total decay heat load for the DSC in HSM-1 was calculated to be $4.1 \mathrm{~kW}$ as of June 2012. Figure S.1 shows an image of the computational volume mesh for the HSM-1 and HSM-15 modules. Figures S.2 and S.3 further illustrate the detailed mesh of these two models with planar slices through the HSM-15 model at the mid-line longitudinally and in the transverse direction.
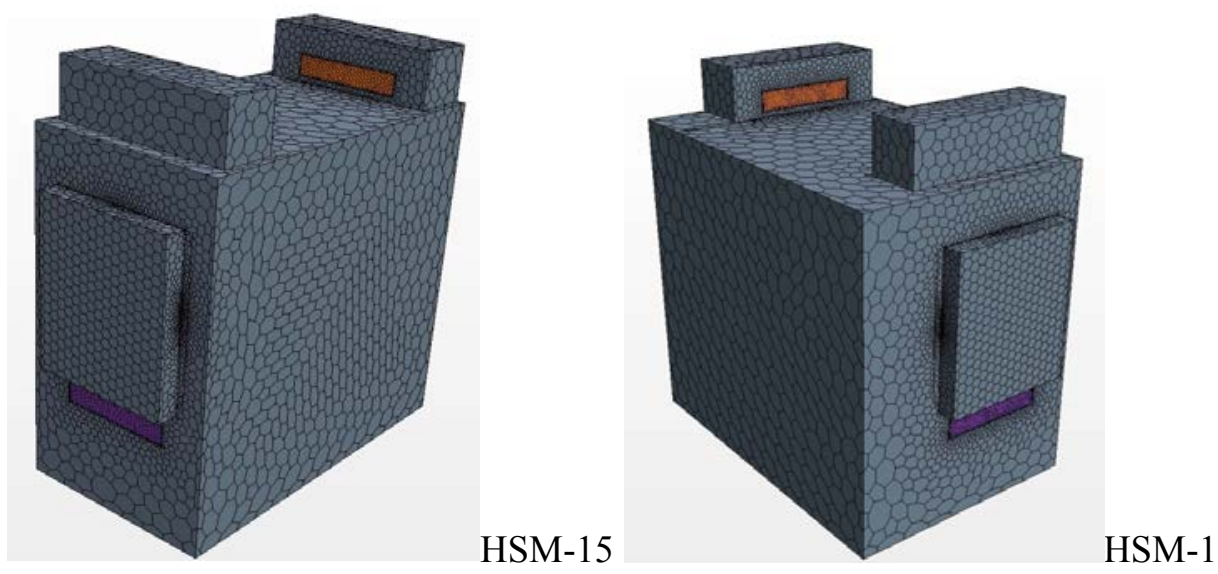

Figure S.1. Volume Mesh of HSM-15 Assembly: Exterior View 


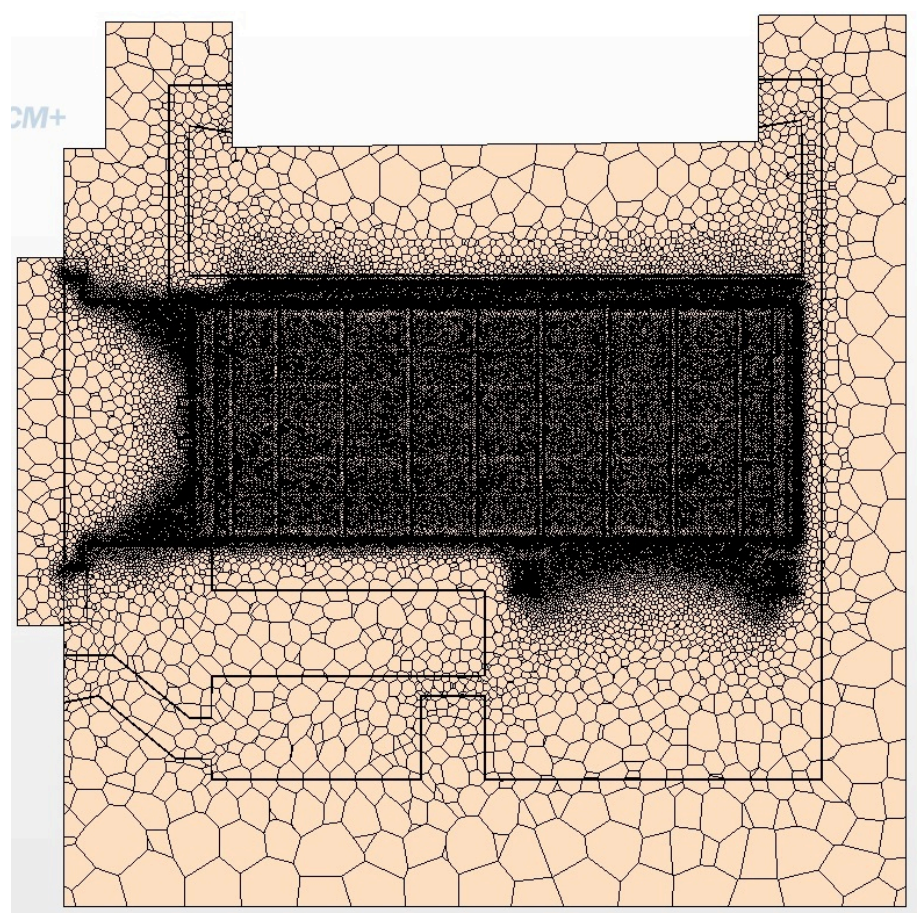

Figure S.2. Planar Slice Through Centerline Showing Volume Mesh of HSM-15 and 24P DSC Model in Axial Direction

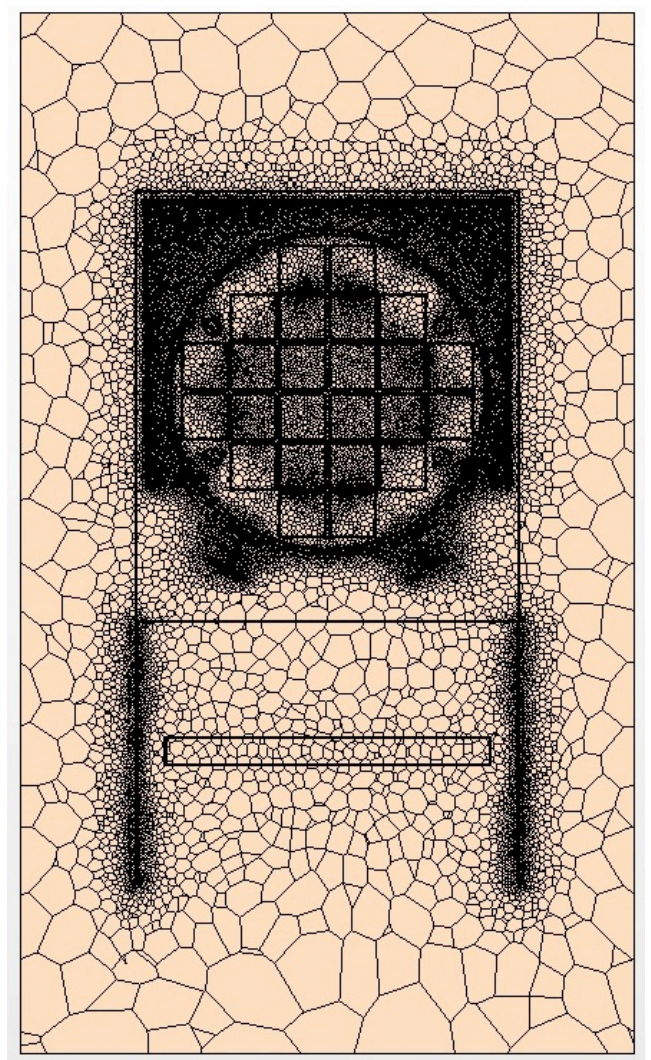

Figure S.3. Planar Slice Through Mid-line Showing Volume Mesh of HSM-15 and 24P DSC Model in Transverse Direction 
The base case for thermal evaluation of the 24P DSC in HSM-15 assumed an ambient temperature of $58^{\circ} \mathrm{F}\left(14^{\circ} \mathrm{C}\right)$. This value was determined using historical climatology data from a National Oceanic and Atmospheric Administration (NOAA) database, and verified with annual ambient temperature data from monitoring stations at the Calvert Cliffs ISFSI. Bounding sensitivity studies on the effect of ambient air temperature were performed for two cases; a 'summer case' at $77^{\circ} \mathrm{F}$ based on average temperatures in July, and a 'winter case' at $35^{\circ} \mathrm{F}$, based on average temperatures in January. Figure S.4 shows the cooling air velocity distribution and Figure S.5 shows the air and concrete temperature distributions predicted with the STAR-CCM+ model for the base case. Figure S.6 illustrates the temperature distribution on the DSC shell surface.

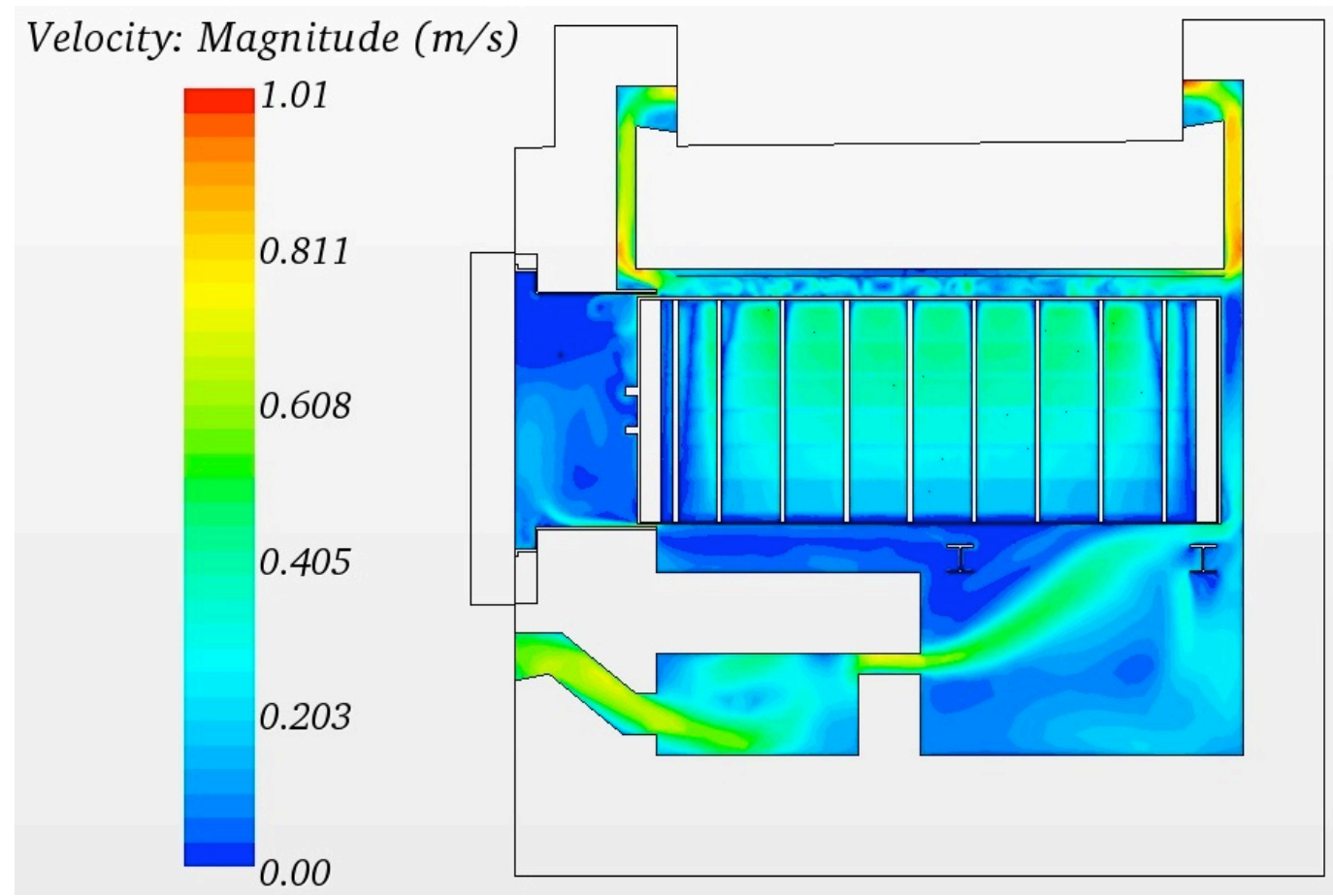

Figure S.4. Velocity at Axial Midplane for Base Case (HSM-15) $-58^{\circ} \mathrm{F}\left(14^{\circ} \mathrm{C}\right)$ Ambient Air
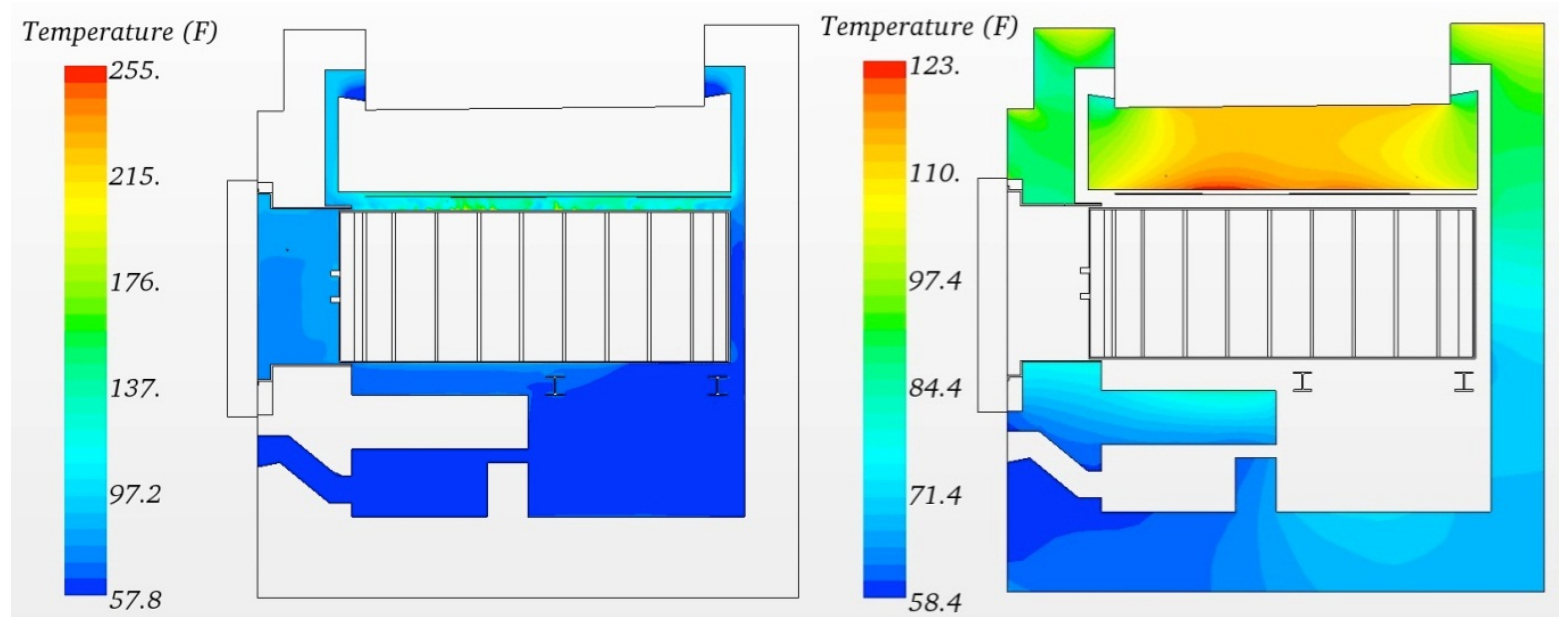

Figure S.5. Air and Concrete Temperature Distributions at Axial Midplane for Base Case (HSM-15) $58^{\circ} \mathrm{F}\left(14^{\circ} \mathrm{C}\right)$ Ambient Air 


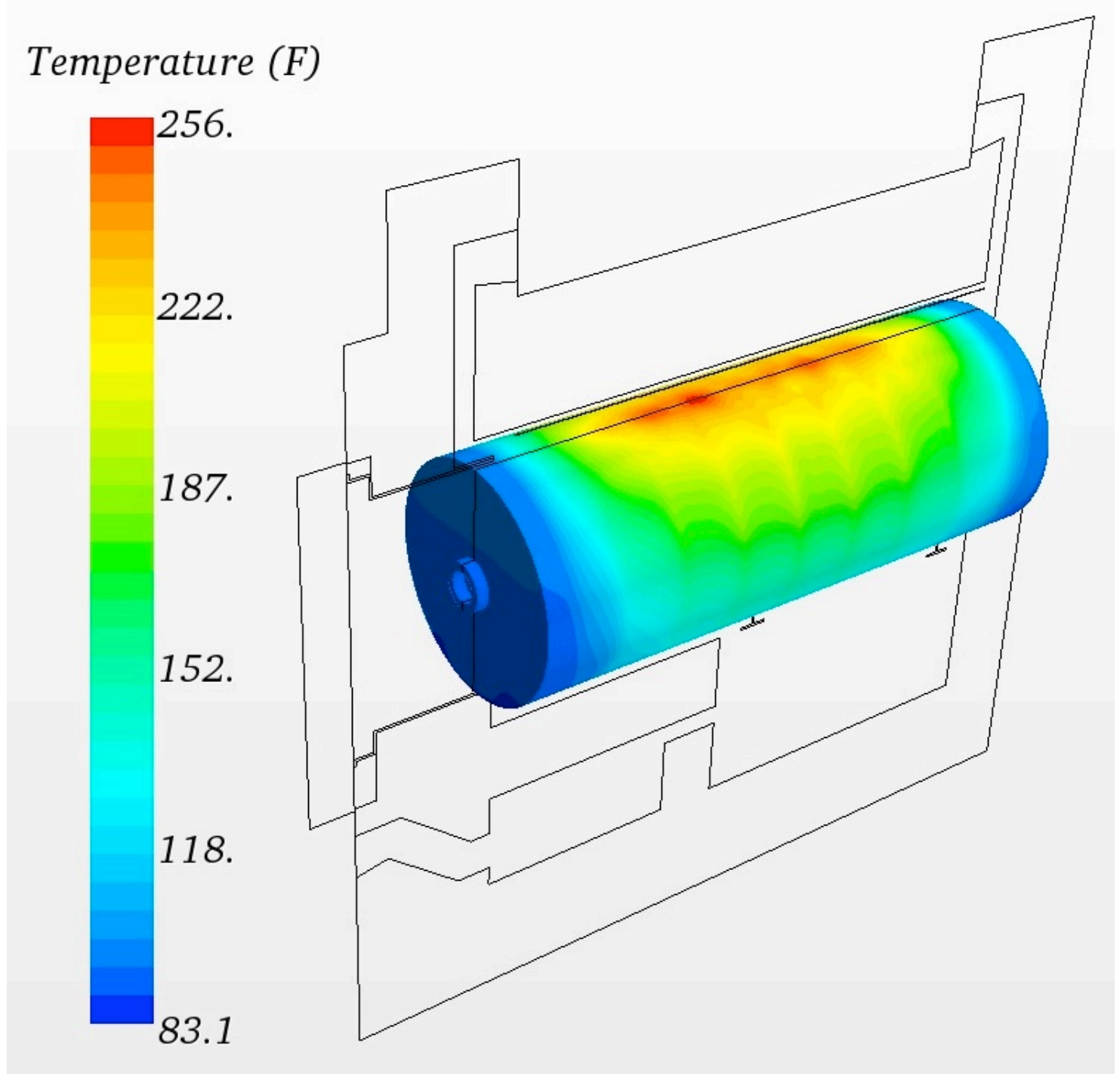

Figure S.6. DSC Shell Surface Temperatures for Base Case (HSM-15) $-58^{\circ} \mathrm{F}\left(14^{\circ} \mathrm{C}\right)$ Ambient

On June $27^{\text {th }}$ and $28^{\text {th }}, 2012$, visual inspections, surface sampling, and temperature measurements were performed on HSM-1 and HSM-15 at the Calvert Cliffs Nuclear Power Station ISFSI. Due to physical constraints on the accessible regions of the DSC and considerations of worker safety, reliable temperature measurements were obtained only on the exposed face of the canister base. Temperature measurements were taken by touching a hand-held thermocouple probe to the surface of the canister and recording the reading on a data sheet. Figure S.7 illustrates the specific locations sampled in this manner on the accessible exposed face of the canister (which is the canister base, due to the prescribed loading configuration). 


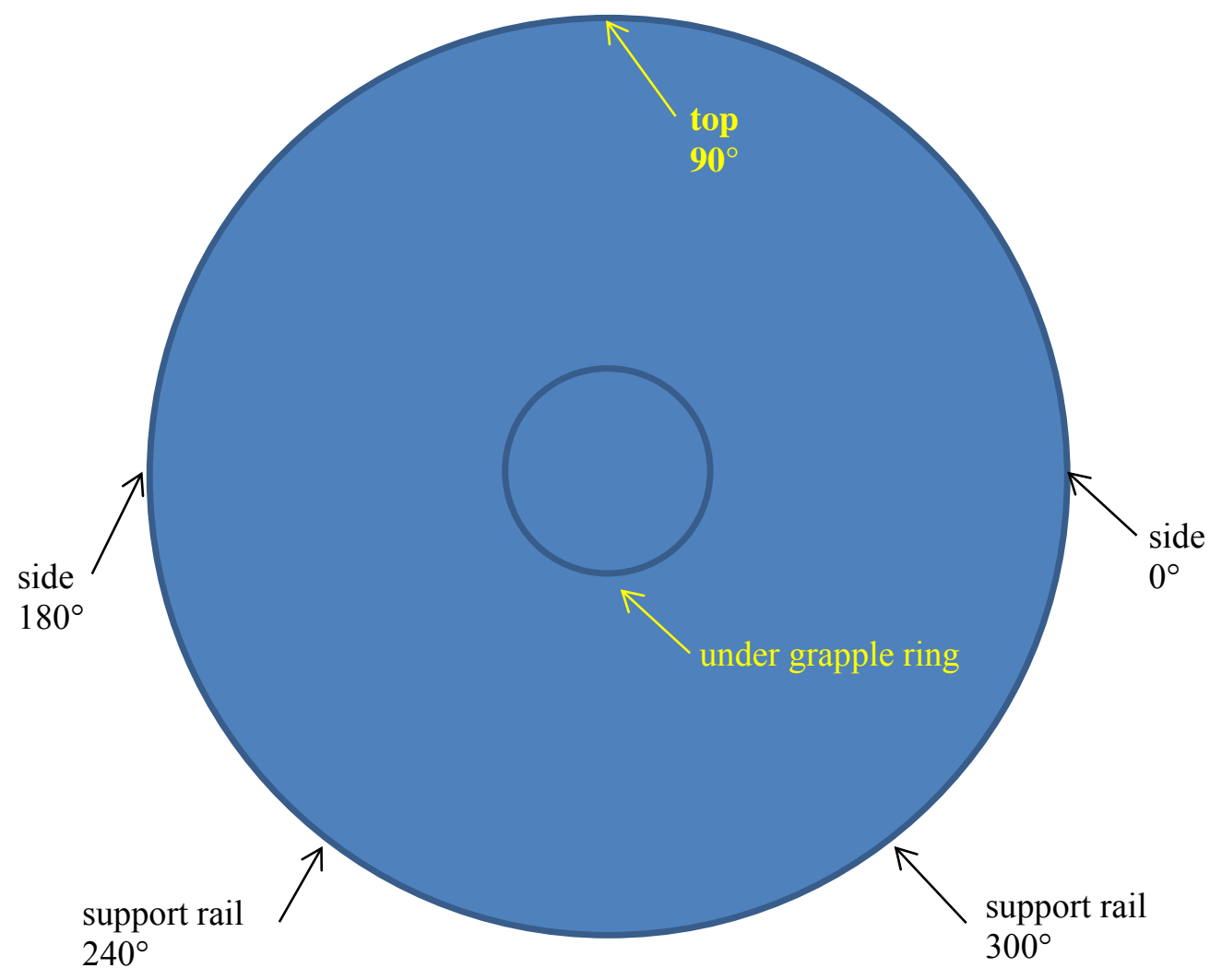

Figure S.7. Location of Temperature Measurements on DSC Base

Modeling results had been produced prior to the date the measurements were obtained, and were in reasonable agreement with the measured temperatures. However, subsequent evaluations identified three important items of modeling information that had not been available prior to the test date, which could be expected to have a noticeable influence on the model predictions. These included

- additional protective screening on the inlet and outlet vents of the storage module, which would increase the inlet and outlet pressure drops, and would have some effect on the total air flow rate through the system

- the actual ambient temperature at the time of testing was significantly warmer than the seasonal average assumed for the pre-test predictions $\left(77^{\circ} \mathrm{F}\left(25^{\circ} \mathrm{C}\right)\right.$ seasonal average, compared to the actual daily average of $82^{\circ} \mathrm{F}\left(28^{\circ} \mathrm{C}\right)$ over the 6 days prior to testing.)

- new information on the axial positioning of the fuel within the DSC, which affected the assumed distribution of the decay heat load within the model

The HSM-1 and HSM-15 models were modified to account for these differences from the original pre-test modeling assumptions. Table S.1 presents the results obtained for the pre-test and post-test configurations of the models, in comparison to the measured temperature data. The general effect of these changes was to increase predicted temperatures on the base of the DSC by a relatively small 
amount. Table S.1 compares the measured temperatures to the predicted temperatures at the 'under grapple ring' location, which is the only location where measurements were obtained for both DSCs.

Table S.1. Effect of Modeling Changes on Predicted Temperatures at 'Under Grapple Ring' Location

\begin{tabular}{|c|c|c|c|c|c|}
\hline \multirow[b]{2}{*}{ module } & \multirow[b]{2}{*}{$\begin{array}{c}\text { measured } \\
\text { temperature } \\
\left({ }^{\circ} \mathbf{F}\left({ }^{\circ} \mathrm{C}\right)\right) \\
\end{array}$} & \multicolumn{4}{|c|}{ Model Results } \\
\hline & & $\begin{array}{c}\text { (pre-test) } \\
\text { without } \\
\text { additional } \\
\text { screens, } 77^{\circ} \mathrm{F} \\
\text { ambient } \\
\left({ }^{\circ} \mathrm{F}\left({ }^{\circ} \mathrm{C}\right)\right) \\
\end{array}$ & $\begin{array}{c}\text { (post-test) } \\
\text { with } \\
\text { additional } \\
\text { screens, } 77^{\circ} \mathrm{F} \\
\text { ambient } \\
\left({ }^{\circ} \mathrm{F}\left({ }^{\circ} \mathrm{C}\right)\right) \\
\end{array}$ & $\begin{array}{c}\text { (post-test) } \\
\text { with } \\
\text { additional } \\
\text { screens, } 82^{\circ} \mathrm{F} \\
\text { ambient } \\
\left({ }^{\circ} \mathrm{F}\left({ }^{\circ} \mathrm{C}\right)\right) \\
\end{array}$ & $\begin{array}{c}\text { (post-test) } \\
\text { with screens, } \\
82^{\circ} \mathrm{F} \text { ambient, } \\
\text { updated fuel } \\
\text { axial position } \\
\text { within DSC } \\
\left({ }^{\circ} \mathrm{F}\left({ }^{\circ} \mathrm{C}\right)\right) \\
\end{array}$ \\
\hline HSM-1 & $112(44)$ & $100(38)$ & $100(38)$ & $106(41)$ & $113(45)$ \\
\hline HSM-15 & $124(51)$ & $110(43)$ & $111(44)$ & $116(47)$ & $127(53)$ \\
\hline
\end{tabular}

The post-test modifications to the model result in a more accurate representation of the conditions in the modules when measurements were taken. The general effect of these changes is to increase predicted temperatures within these systems. Table S.2 illustrates this effect with a comparison of pre-test and posttest peak component temperatures predicted with both the HSM-1 and HSM-15 models. Table S.3 shows a comparison of the pre-test and post-test results of the temperatures measured at the 'under grapple ring' location and the 0.0 -inch side locations on the exposed face of the DSC. These are the only measured temperatures for which there is sufficient confidence to proceed with a direct comparison between model results and the TC measurements.

Table S.2. Maximum Temperatures from CFD Models: Pre-test and Post-test Results

\begin{tabular}{|l|c|c|c|c|}
\hline & $\begin{array}{c}\text { Concrete } \\
\text { temperature } \\
\left({ }^{\circ} \mathrm{F}\left({ }^{\circ} \mathrm{C}\right)\right)\end{array}$ & $\begin{array}{c}\mathrm{DSC} \\
\text { temperature } \\
\left({ }^{\circ} \mathrm{F}\left({ }^{\circ} \mathrm{C}\right)\right)\end{array}$ & $\begin{array}{c}\text { Fuel } \\
\text { temperature } \\
\left({ }^{\circ} \mathrm{F}\left({ }^{\circ} \mathrm{C}\right)\right)\end{array}$ & $\begin{array}{c}\text { Heat Shield } \\
\text { temperature } \\
\left({ }^{\circ} \mathrm{F}\left({ }^{\circ} \mathrm{C}\right)\right)\end{array}$ \\
\hline HSM-1 (Pre-test) & $128(53)$ & $197(92)$ & $265(129)$ & $134(57)$ \\
\hline HSM-1 (Post-test) & $133(56)$ & $208(98)$ & $279(137)$ & $143(62)$ \\
\hline HSM-15 (Pre-test) & $145(63)$ & $278(137)$ & $402(206)$ & $166(74)$ \\
\hline HSM-15 (Post-test) & $158(70)$ & $290(143)$ & $422(217)$ & $187(86)$ \\
\hline
\end{tabular}


Table S.3. Post-Test Model Temperatures Compared to Measured Data

\begin{tabular}{|c|c|c|c|c|}
\hline \multirow[b]{2}{*}{ Temperature Location } & \multicolumn{4}{|c|}{ Temperature $\left({ }^{\circ} \mathrm{F}\left({ }^{\circ} \mathrm{C}\right)\right)$} \\
\hline & $\begin{array}{c}\mathrm{TC} \\
\text { measurement } \\
\text { HSM-1 }\end{array}$ & $\begin{array}{c}\mathrm{TC} \\
\text { measurement } \\
\text { HSM-15 }\end{array}$ & $\begin{array}{c}\text { HSM-1 } \\
\text { Model } \\
\text { (post-test) }\end{array}$ & $\begin{array}{c}\text { HSM-15 } \\
\text { Model } \\
\text { (post-test) }\end{array}$ \\
\hline Under Grapple Ring & $112(44)$ & $124(51)$ & $113(45)$ & $127(53)$ \\
\hline Side $\left(0^{\circ}\right)-0.0$ inches & $108(42)$ & $\mathrm{n} / \mathrm{a}$ & $113(45)$ & $127(53)$ \\
\hline Top $\left(90^{\circ}\right)-0.0$ inches & $115(46)$ & $\mathrm{n} / \mathrm{a}$ & $116(47)$ & $133(56)$ \\
\hline Side $\left(180^{\circ}\right)-0.0$ inches & $104(40)$ & $\mathrm{n} / \mathrm{a}$ & $113(45)$ & $128(53)$ \\
\hline Rail $\left(240^{\circ}\right)-0.0$ inches & $106(41)$ & $\mathrm{n} / \mathrm{a}$ & $107(42)$ & $118(48)$ \\
\hline Rail $\left(300^{\circ}\right)-0.0$ inches & $105(41)$ & $\mathrm{n} / \mathrm{a}$ & $107(42)$ & $118(48)$ \\
\hline
\end{tabular}

Additional modeling sensitivity studies were performed to investigate the effect of including detailed representation of the fuel assembly end fittings in the fuel region effective axial thermal conductivity. These evaluations also included investigation of the sensitivity of results to the representation of the guide sleeves with a non-conformal mesh, compared to the simplification of using thermal resistance connections. Table S.4 summarizes the results, in comparison to the 'under grapple ring' measurements, and shows the effect on predicted peak cladding temperature.

Table S.4. Post-Test Model Sensitivity Evaluations

\begin{tabular}{|c|c|c|c|c|}
\hline \multirow[b]{2}{*}{ Module/location } & \multicolumn{4}{|c|}{ Temperature $\left({ }^{\circ} \mathrm{F}\left({ }^{\circ} \mathrm{C}\right)\right)$} \\
\hline & $\begin{array}{c}\mathrm{TC} \\
\text { measurement }\end{array}$ & (post-test) & $\begin{array}{c}\text { modified } \\
\text { axial } \\
\text { effective } \\
\text { conductivity }\end{array}$ & $\begin{array}{l}\text { guide } \\
\text { sleeves } \\
\text { meshed }\end{array}$ \\
\hline \multicolumn{5}{|l|}{ HSM-1 } \\
\hline under grapple ring & $112(44)$ & $113(45)$ & $120(49)$ & $117(47)$ \\
\hline peak fuel cladding & $\mathrm{n} / \mathrm{a}$ & $279(137)$ & $271(133)$ & $262(128)$ \\
\hline \multicolumn{5}{|l|}{ HSM-15 } \\
\hline under grapple ring & $124(51)$ & $127(53)$ & $138(59)$ & $134(57)$ \\
\hline peak fuel cladding & $\mathrm{n} / \mathrm{a}$ & $422(217)$ & $412(211)$ & $398(203)$ \\
\hline
\end{tabular}

The above tables show that the HSM-1 and HSM-15 model predictions are in good agreement with the measured temperatures near the base of the DSC. The temperature of the DSC surface in this region is not particularly interesting in and of itself, but it is a convenient benchmark illustrating that CFD modeling of the storage system can yield reasonably accurate temperatures and temperature distributions 
at realistic decay heat loads. The results in Table S.4 show that with increased refinement of the modeling of the fuel region, the predicted 'under grapple ring' temperature increases slightly. This is consistent with the expectation that the measured temperatures are slightly low, compared to temperatures that would exist at this location with the module lid in place and airflow around the DSC undisturbed. More significantly, refinement of the fuel region tends to result in lower predicted peak cladding temperatures, as the inherent conservatism in the homogeneous fuel effective conductivity model is reduced. 


\section{Acknowledgments}

This work was greatly aided by having access to the SolidWorks ${ }^{\circledR}$ model of the HSM-15 module provided by John Kessler and Keith Waldrop of EPRI. TransNuclear generously allowed the measured data to be shared and published. Special thanks are owed to John Massari of Constellation Energy Nuclear Group, Nuclear Analysis Supervisor at the Calvert Cliffs Nuclear Power Station, for providing detailed as-built information on the module and the DSC, and on the fuel loading of the DSCs in HSM-1 and HSM-15. 


\section{Acronyms and Abbreviations}

$\begin{array}{ll}\text { CAD } & \text { Computer Aided Design } \\ \text { CFD } & \text { Computational Fluid Dynamics } \\ \text { DOE } & \text { Department of Energy } \\ \text { DOE-NE } & \text { Department of Energy-Nuclear Energy } \\ \text { DSC } & \text { Dry Storage Canister } \\ \text { EPRI } & \text { Electric Power Research Institute } \\ \text { GWd/MTU } & \text { Gigawatt days per metric ton uranium (measure of burnup) } \\ \text { HSM } & \text { Horizontal Storage Module } \\ \text { ISFSI } & \text { Independent Spent Fuel Storage Installation } \\ \text { MCNP } & \text { Monte Carlo Neutral Particle (model) } \\ \text { NCDC } & \text { National Climatic Data Center } \\ \text { NOAA } & \text { National Oceanic and Atmospheric Administration } \\ \text { ORNL } & \text { Oak Ridge National Laboratory } \\ \text { PCT } & \text { Peak Clad Temperature } \\ \text { PNNL } & \text { Pacific Northwest National Laboratory } \\ \text { SNF } & \text { Spent Nuclear Fuel } \\ \text { UNF } & \text { Used Nuclear Fuel }\end{array}$




\section{Contents}

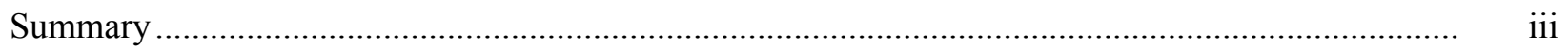

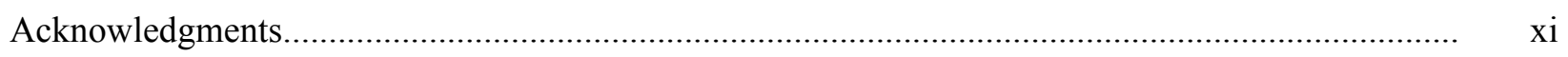

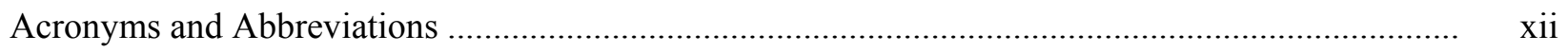

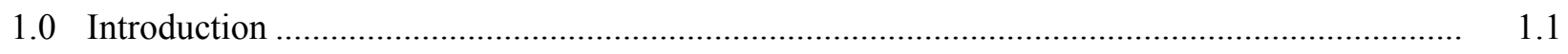

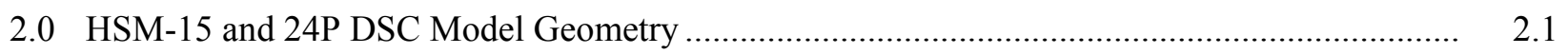

3.0 STAR-CCM+ Model Mesh .....................................................................................

4.0 STAR-CCM+ Model Materials ........................................................................................ 4.1

4.1 Fuel Effective Conductivity Model ........................................................................... 4.1

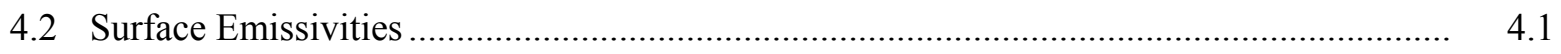

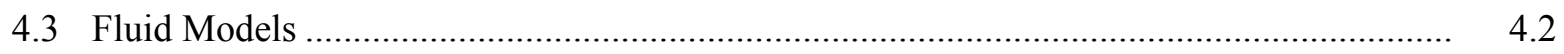

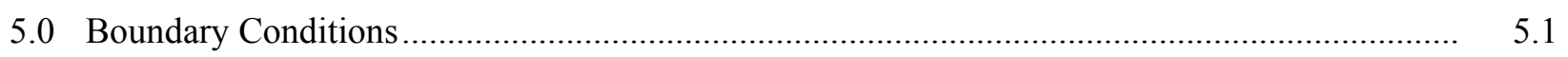

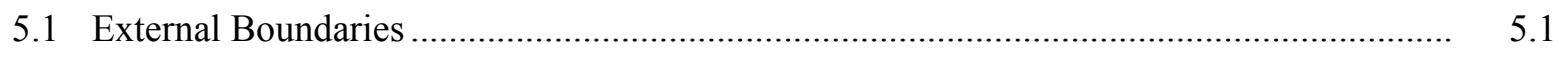

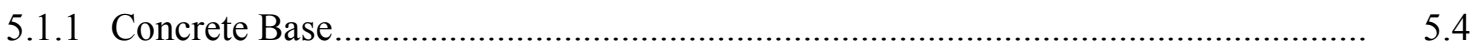

5.1.2 External Convection Boundaries................................................................. 5.4

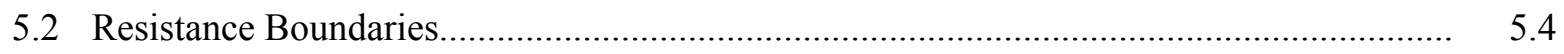

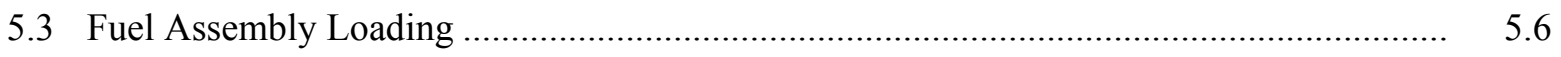

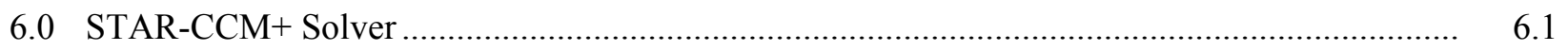

7.0 Thermal Modeling Results and Discussion ....................................................................

7.1 Results for Base Case (HSM-15) ............................................................................ 7.2

7.2 Effect of Seasonal Ambient Temperature Variation .................................................... 7.8

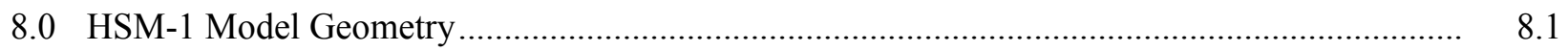

8.1 HSM-1 Model Results............................................................................................. 8.4

9.0 Model Results Compared to Measured Temperatures.......................................................... 9.1

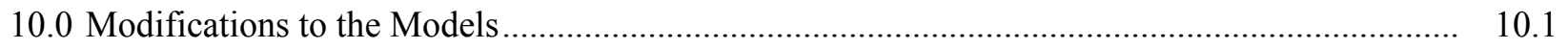

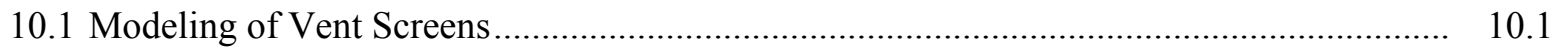

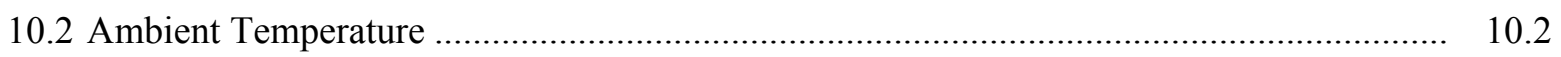

10.3 Post-Test Modeling Results ................................................................................... 10.3

10.4 Post-Test Fuel Region Modeling Evaluations ........................................................... 10.8

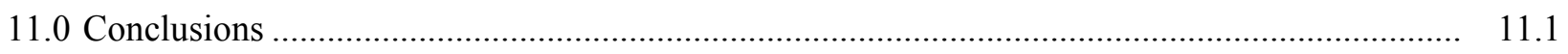

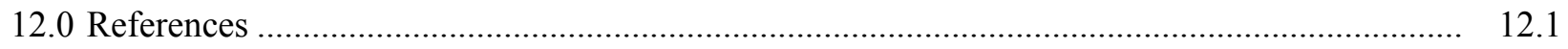

Appendix A Material Properties ............................................................................................. A.1

Appendix B External Heat Transfer Model ......................................................................... B.1

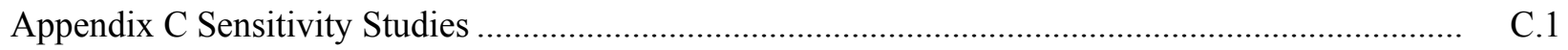

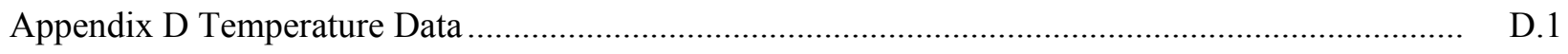




\section{Figures}

Figure 1.1. Aerial View of Calvert Cliffs Nuclear Power Station ISFSI, Showing Array of Six $2 \mathrm{x}$ 6 Blocks of Storage Modules (Image U.S. Geologic Survey, Imagery Date: 2/28/2007, (C) 2011 Google)

Figure 1.2. Typical NUHOMS Storage Module in Calvert Cliffs Nuclear Power Station ISFSI, Showing Front Air Inlet Vent and Open Doorway for DSC Insertion (from ISOE 2012)

Figure 2.1. CAD Geometry of NUHOMS HSM-15 Storage Module Developed by EPRI

Figure 2.2. Illustrative Diagrams of 24P DSC Geometry (Images courtesy of AREVA)

Figure 2.3. Mid-Plane Cross-Sectional View and Exterior View of Internal Geometry in SolidWorks ${ }^{\circledR}$ Model of 24P DSC.....

Figure 3.1. Volume Mesh of HSM-15 Assembly: Exterior View

Figure 3.2. Planar Slice Through Centerline Showing Volume Mesh of HSM-15 and 24P DSC

Model in Axial Direction

Figure 3.3. Planar Slice Through Mid-line Showing Volume Mesh of HSM-15 and 24P DSC Model in Transverse Direction

Figure 3.4. Merged Axial and Transverse Cross-sections, Illustrating Overall Volume Mesh of Internal Regions.

Figure 5.1. Historical Weather Data for Calvert Cliffs Region: Annual Maximum and Minimum Monthly Average Temperatures over the Past 100 Years

Figure 5.2. Annual Average Diurnal Temperature Variation at Calvert Cliffs ISFSI (Based on Temperature Data from 2010)

Figure 5.3. Fuel Assembly Loading and Identification Numbers

Figure 5.4. Burn-up Profiles from Calvert Cliffs CE14x14 Fuel Compared to Bounding Axial Peaking Factor for Low Burnup ( $<35$ GWd/MTU (average)) Spent Fuel (DOE/RW-0472, 1998).

Figure 7.1. Velocity at Axial Midplane for Base Case (HSM-15) $-58^{\circ} \mathrm{F}\left(14^{\circ} \mathrm{C}\right)$ Ambient Air.....

Figure 7.2. Air and Concrete Temperature Distributions at Axial Midplane for Base Case (HSM15) $-58^{\circ} \mathrm{F}\left(14^{\circ} \mathrm{C}\right)$ Ambient Air

Figure 7.3. DSC Shell Surface Temperatures for Base Case (HSM-15) $-58^{\circ} \mathrm{F}\left(14^{\circ} \mathrm{C}\right)$ Ambient

Figure 7.4. Line Probe Locations for Extracting Temperature Results from STAR-CCM+ Model (NOTE: Image Resolution of Probe Locations is not to Scale)

Figure 7.5. Calculated Temperatures on DSC Shell for Base Case (HSM-15) $-58^{\circ} \mathrm{F}\left(14^{\circ} \mathrm{C}\right)$ Ambient

Figure 7.6. Calculated Temperatures: Top of DSC Shell, Centerline of Top Heat Shield, and Centerline of Concrete Ceiling, for Base Case (HSM-15) $-58^{\circ} \mathrm{F}\left(14^{\circ} \mathrm{C}\right)$ Ambient.

Figure 7.7. Calculated Temperatures: Sides of DSC Shell, Side Heat Shields, and Concrete Side Walls, for Base Case (HSM-15) $-58^{\circ} \mathrm{F}\left(14^{\circ} \mathrm{C}\right)$ Ambient

Figure 7.8. Temperature Distribution in Central Cross-section of HSM- 15 for Base Case $-58^{\circ} \mathrm{F}$ $\left(14^{\circ} \mathrm{C}\right)$ Ambient.

Figure 7.9. Temperature Distribution in Central Cross-section of HSM-15 for Summer Case $77^{\circ} \mathrm{F}\left(25^{\circ} \mathrm{C}\right)$ Ambient. 
Figure 7.10. Temperature Distribution in Central Cross-section of HSM-15 for Winter Case $35^{\circ} \mathrm{F}\left(2^{\circ} \mathrm{C}\right)$ Ambient

Figure 7.11. Temperature Distribution in Central Cross-section of HSM-15 for June Average Case $-72^{\circ} \mathrm{F}\left(22^{\circ} \mathrm{C}\right)$ Ambient

Figure 7.12. Calculated Temperatures: Top of DSC Shell, Bounding Seasonal Variation - Base Case at $58^{\circ} \mathrm{F}\left(14^{\circ} \mathrm{C}\right)$, Summer Case at $77^{\circ} \mathrm{F}\left(25^{\circ} \mathrm{C}\right)$, Winter Case at $35^{\circ} \mathrm{F}\left(2^{\circ} \mathrm{C}\right)$ 7.13

Figure 8.1. Volume Mesh of HSM-1 Assembly, Exterior View

Figure 8.2. Fuel Assembly Loading and Identification Numbers for HSM-1

Figure 8.3. Calculated Temperatures: Top of DSC Shell, Centerline of Top Heat Shield, and Centerline of Concrete Ceiling, for Summer Case (HSM-1) - Ambient Air $77^{\circ} \mathrm{F}\left(25^{\circ} \mathrm{C}\right)$

Figure 8.4. Calculated Temperatures: Sides of DSC Shell, Side Heat Shields, and Concrete Side Walls, for Summer Case (HSM-1) - Ambient Air $77^{\circ} \mathrm{F}\left(25^{\circ} \mathrm{C}\right)$

Figure 9.1. Location of Temperature Measurements on DSC Base

9.2

Figure 9.2. Comparison of Measured to Predicted Axial Temperatures on DSC in HSM-1 9.4

Figure 10.1. Comparison of Measured to (Post-test) Predicted Axial Temperatures on DSC Surface in HSM-1 10.5

Figure 10.2. Axial Temperature Comparison at Top of DSC in HSM-1 10.6

Figure 10.3. Axial Temperature Comparison on Sides of DSC in HSM-1 10.6

Figure 10.4. Axial Temperature Comparison at Support Rail Locations for DSC in HSM-1 10.7

Figure 10.5. Axial Temperature Comparison for Top Heat Shield, Air Above DSC, and DSC Top Surface in HSM-1 


\section{Tables}

Table 4.1. Emissivity Values for Radiation Heat Transfer ......................................................... 4.2

Table 5.1. Ambient Air Temperature Range Evaluated................................................................... 5.3

Table 5.2. Fuel Assembly Decay Heat Loads for DSC in HSM-15 as of June 2012 ....................... 5.7

Table 7.1. Component Maximum and Minimum Temperatures: Base Case (HSM-15) ................... 7.1

Table 8.1. Fuel Assembly Decay Heat Loads for DSC in HSM-1 as of June 2012 ......................... 8.3

Table 8.2. Component Maximum and Minimum Temperatures: Summer Case (HSM-1)................ $\quad 8.4$

Table 9.1. Comparison of Measured and Predicted Temperatures (Pre-test Models) ....................... 9.3

Table 10.1. Daily Temperature Data at Calvert Cliffs from NCDC .............................................. 10.3

Table 10.2. Effect of Modeling Changes on Predicted Temperatures at 'Under Grapple Ring'

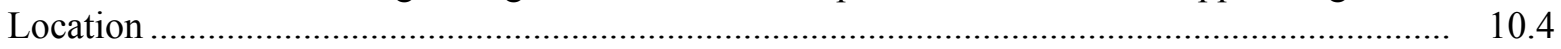

Table 10.3. Maximum Temperatures from CFD Models: Pre-test and Post-test Results .................. 10.4

Table 10.4. Post-Test Model Temperatures Compared to Measured Data ........................................ 10.5

Table 10.5. Results of Fuel Region Modeling Evaluations ...................................................... 10.9 


\subsection{Introduction}

As part of the Used Fuel Disposition Campaign of the U. S. Department of Energy, Office of Nuclear Energy (DOE-NE) Fuel Cycle Research and Development, a consortium of national laboratories ${ }^{1}$ and industry $^{2}$ performed visual inspections and temperature measurements of two storage modules in the Calvert Cliffs Nuclear Power Station's Independent Spent Fuel Storage Installation (ISFSI). The portion of the work on this program being done at Pacific Northwest National Laboratory (PNNL) includes thermal analysis in support of extended storage of used or spent nuclear fuel (UNF/SNF). The data obtained in the inspections at Calvert Cliffs provide an opportunity to develop structural and thermal models that can yield realistic temperature predictions for actual storage systems, in contrast to conservative and bounding design basis calculations.

As part of this effort, a detailed model of the concrete storage module to be examined was developed by Electric Power Research Institute (EPRI) using SolidWorks ${ }^{\circledR}$ (Dassault Systemes, 2011), a 3-D computer aided design (CAD) package. The specific module represented in this model is HSM-15, an inner module in a $2 \times 6$ array of modules. This model was used as a starting point for developing a computational fluid dynamics (CFD) model of the storage module and the dry storage canister (DSC) contained within it, using the STAR-CCM+ package (version 7.02) (CD-Adapco, 2012). The immediate purpose of this modeling effort is to obtain temperature predictions in actual storage conditions for the module, DSC, and DSC contents, including preliminary estimates of fuel cladding temperatures for the SNF.

The long-term goal of this work is to obtain realistic evaluations of thermal performance of actual SNF storage systems over extended periods, which will require developing a detailed COBRA-SFS (Michener, et al., 1987) model of the DSC internals. The approach used in this study does not include many of the conservatisms and bounding assumptions normally used in design-basis and safety-basis calculations for spent fuel storage systems. The results of this study cannot be used in licensing basis evaluations of the Calvert Cliffs ISFSI, or any other spent fuel storage facility.

The primary storage module used for this study is HSM-15 in the Calvert Cliffs Nuclear Power Station's ISFSI. Evolving program considerations resulted in the decision to also examine and take temperature measurements in a second module, HSM-1, which contains a DSC with a much lower decay heat load than that within HSM-15. The storage modules at Calvert Cliffs are a site-specific variant of the standard NUHOMS ${ }^{\circledR}$ design developed by Transnuclear, Inc., in which the spent fuel is sealed within a DSC that is loaded into a horizontal storage module (HSM). Figure 1.1 shows an aerial view of the ISFSI, illustrating the layout of the 12-module (2x6) blocks of storage units. A typical module (ISOE, 2012) in the Calvert Cliffs ISFSI is shown in Figure 1.2 (prior to loading with a DSC, with the front doorway removed).

\footnotetext{
${ }^{1}$ Pacific Northwest National Laboratory (PNNL), Oak Ridge National Laboratory (ORNL), Sandia National Laboratories (SNL), and Idaho National Laboratory (INL)

${ }^{2}$ Electric Power Research Institute (EPRI), TN/AREVA, and Constellation Energy (Owner of Calvert Cliffs Nuclear Power Station)
} 


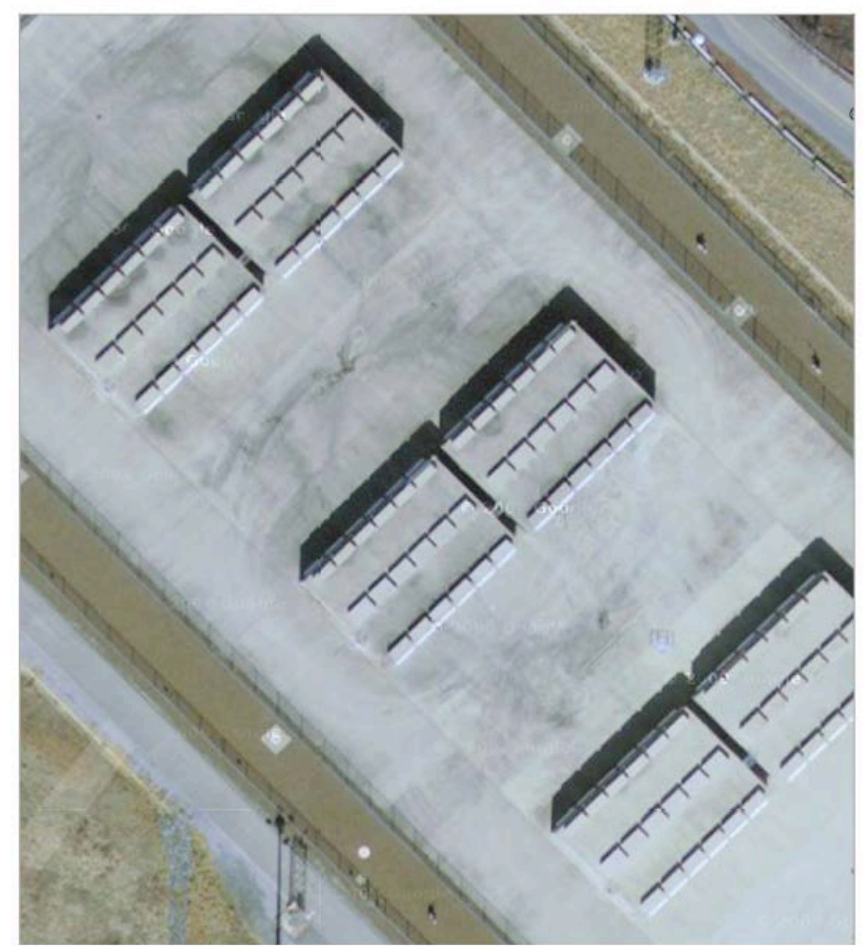

Figure 1.1. Aerial View of Calvert Cliffs Nuclear Power Station ISFSI, Showing Array of Six $2 \times 6$ Blocks of Storage Modules (Image U.S. Geologic Survey, Imagery Date: 2/28/2007, (C) 2011 Google)

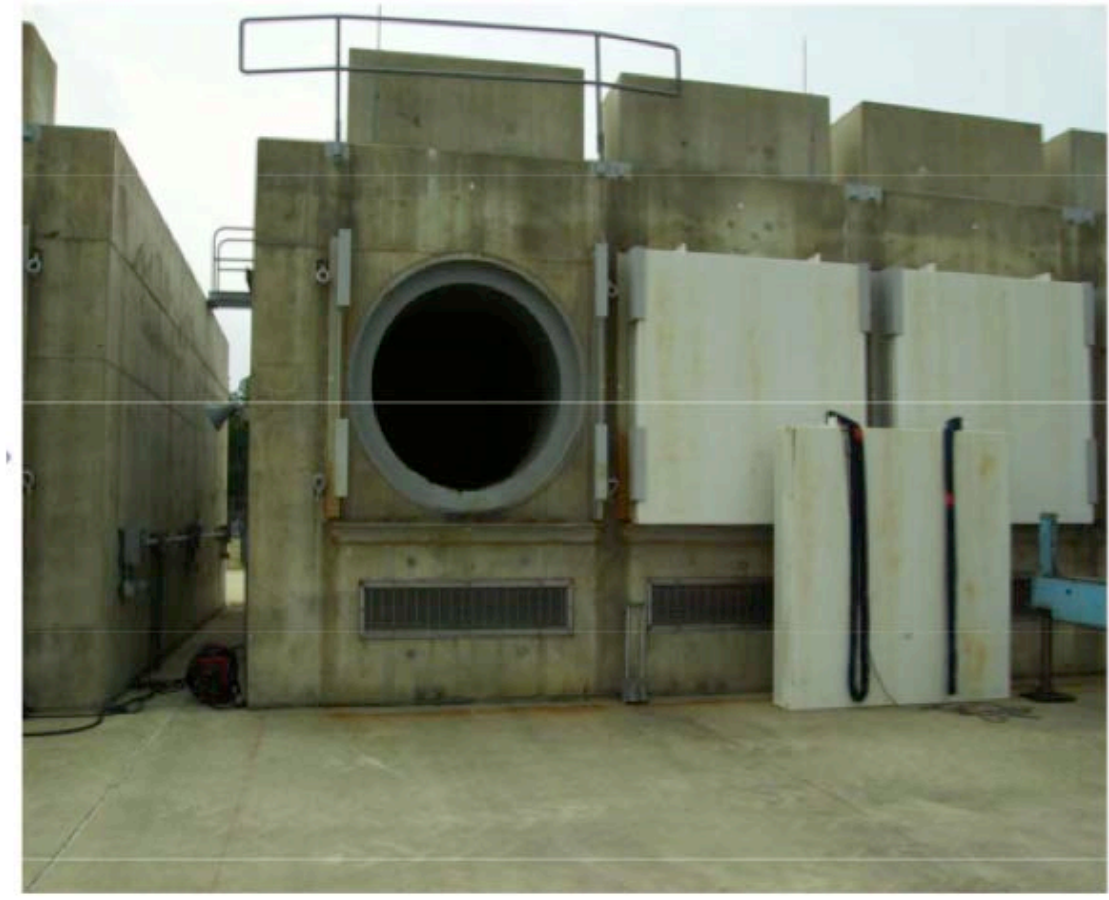

Figure 1.2. Typical NUHOMS Storage Module in Calvert Cliffs Nuclear Power Station ISFSI, Showing Front Air Inlet Vent and Open Doorway for DSC Insertion (from ISOE 2012) 
The model geometry for the HSM-15 is described in detail in Section 2. Section 3 describes the mesh developed for the system. Materials and special modeling considerations for the fuel region and for thermal radiation heat transfer in the system are discussed in Section 4. The boundary conditions and modeling assumptions for the simulations to obtain predictions of long-term temperatures in the module are presented in Section 5. The numerical methods used to evaluate fluid dynamics and heat transfer mechanisms are discussed in Section 6. Section 7 presents results and discussion of temperature distributions predicted for the HSM-15 module and the DSC within the module, based on the estimated decay heat load in the DSC as of the planned inspection timeframe in June 2012. Modifications to the HSM-15 model to develop a model of the HSM-1 module are described in Section 8. Section 9 contains comparisons between the 'blind' test predictions from the STAR-CCM+ models, and the measured temperatures obtained in the two modules. Section 10 describes the post-test evaluation of the modeling results. Section 11 summarizes the main conclusions developed from this work, and Section 12 contains the list of references cited. 



\subsection{HSM-15 and 24P DSC Model Geometry}

The SolidWorks ${ }^{\circledR}$ model of the HSM-15 storage module provided by EPRI is shown in Figure 2.1. (The DSC is not shown in this image, for clarity.) The concrete walls are imaged in semi-transparent grey, to illustrate the module internals, including the inlet and outlet airflow vents, DSC support structures, and thin steel sheets of shielding on the side walls and ceiling, which protect the concrete walls from the thermal load due to the DSC. This model was modified to include the interior structure of the DSC, consisting of the spacer disks, tie rods, fuel assemblies, and the detailed structure of the DSC top and bottom end caps. Figure 2.2 shows diagrams illustrating the geometry of the 24P DSC (containing 24 pressurized water reactor (PWR) spent fuel assemblies), and Figure 2.3 illustrates the 3-D model of the DSC added to the SolidWorks ${ }^{\circledR}$ model. For simplicity, the stainless steel guide sleeves surrounding the fuel were not represented in the model mesh, since thin-walled components can over-complicate the mesh. The guide sleeves are accounted for in the model through contact resistances specified at boundaries of the fuel regions. The contact resistances are discussed in further details in Section 5.2. The dimensions for the interior components were obtained from the input file of a Monte Carlo Neutral Particle (MCNP) model $^{1}$ for the site-specific 24P DSC design used in the Calvert Cliffs ISFSI.

The 24P DSC assembly was integrated into the SolidWorks ${ }^{\circledR}$ model of the HSM-15 storage module. The overall assembly was then used to create the fluid regions within the module and canister. This included an air region within the storage module and external to the DSC, and a helium-filled region within the DSC.

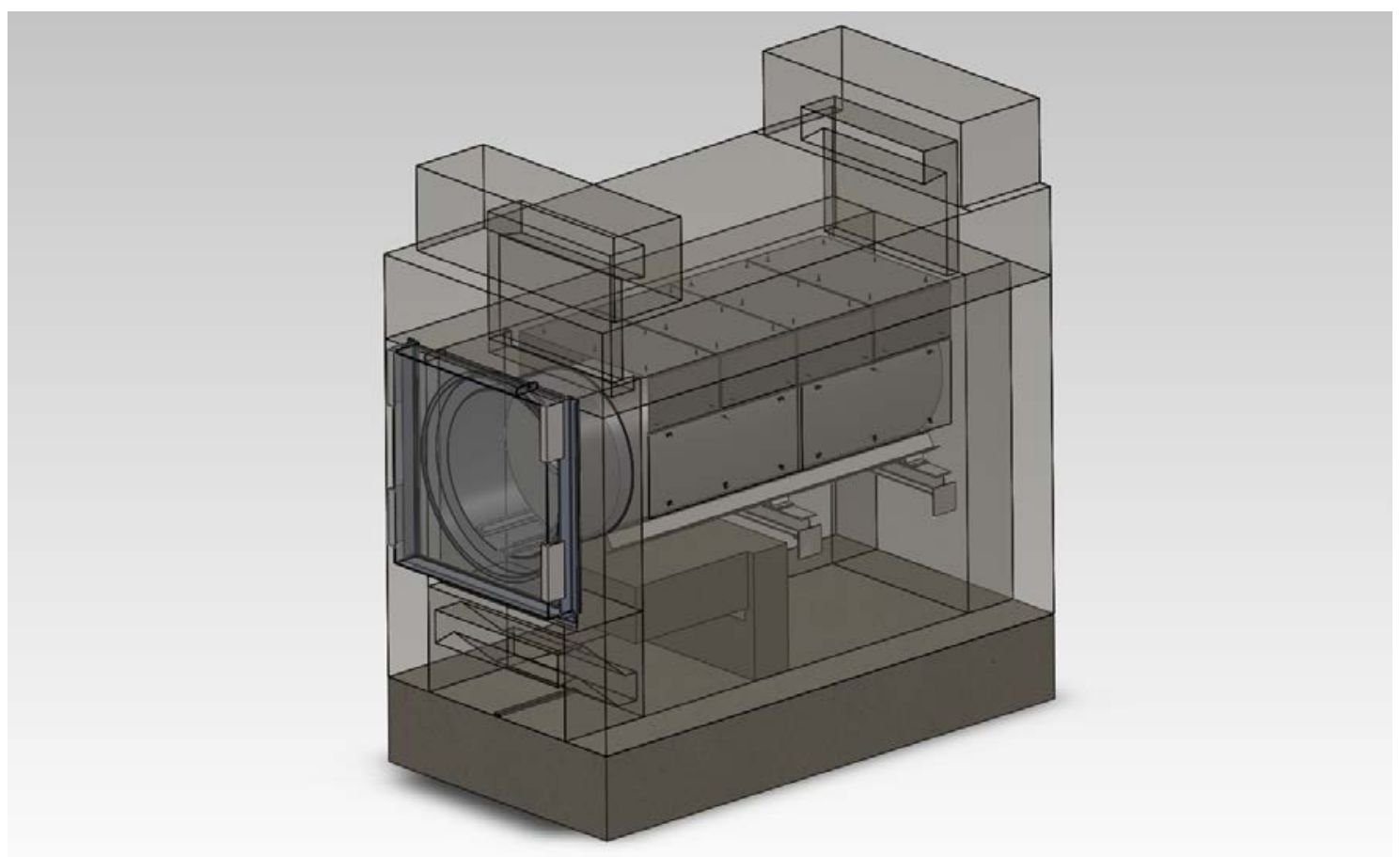

Figure 2.1. CAD Geometry of NUHOMS HSM-15 Storage Module Developed by EPRI

\footnotetext{
${ }^{1}$ The MCNP input model for the 24P DSC within a transfer cask was provided by John Massari of Constellation Energy Nuclear Group, Nuclear Analysis Supervisor at the Calvert Cliffs Nuclear Power Station.
} 

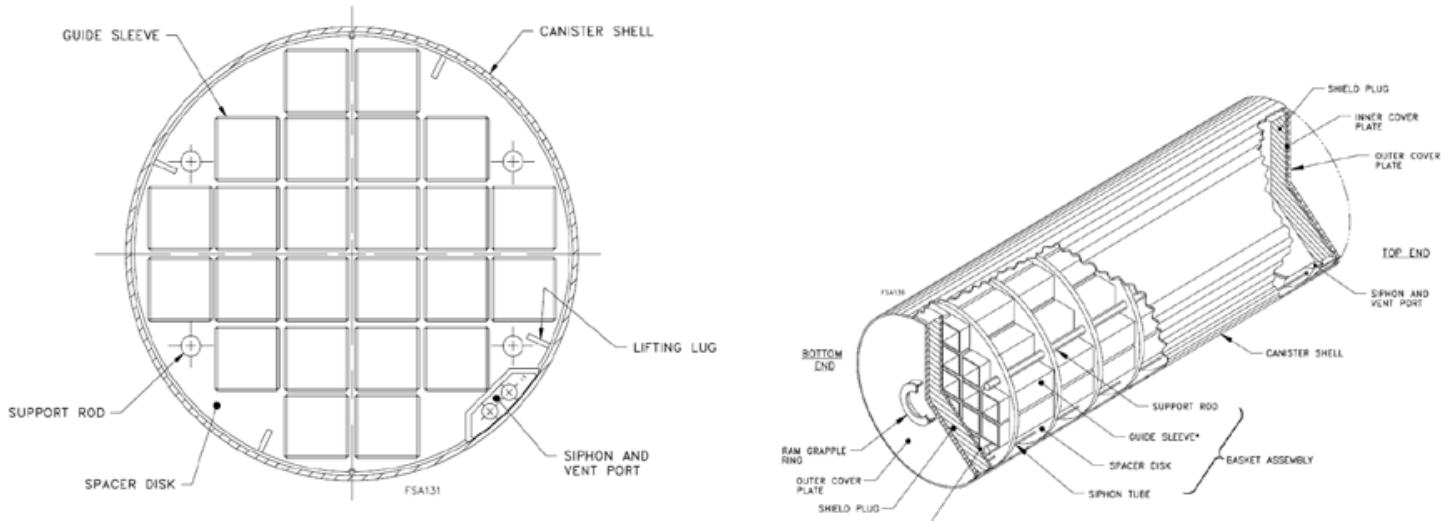

Figure 2.2. Illustrative Diagrams of 24P DSC Geometry (Images courtesy of AREVA)
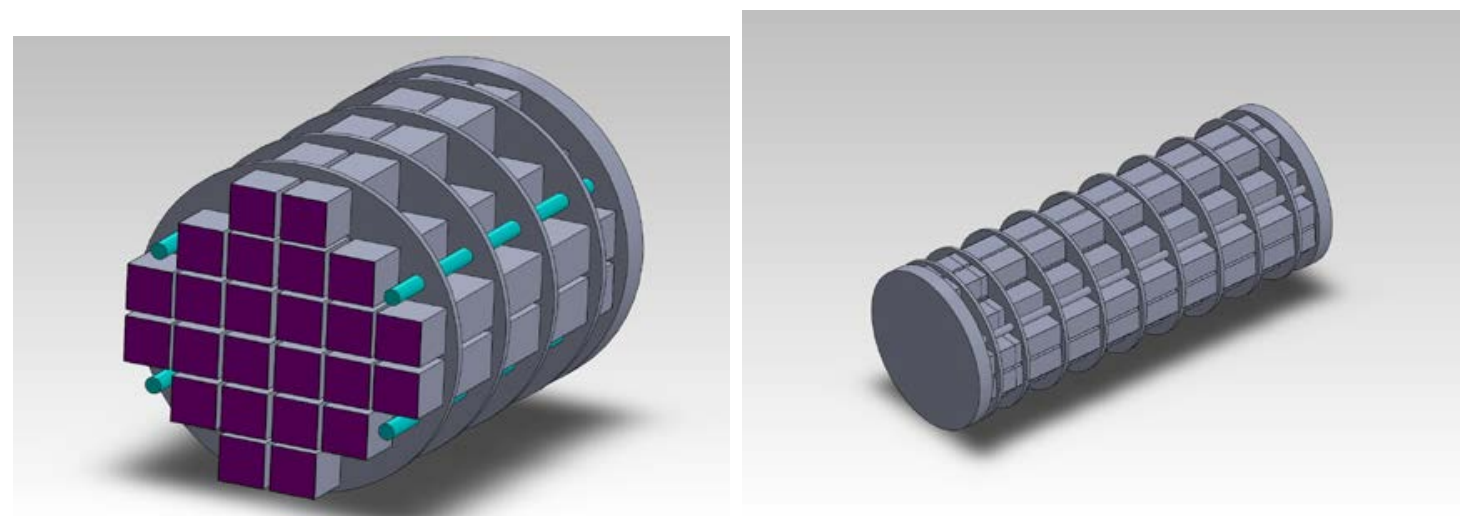

Figure 2.3. Mid-Plane Cross-Sectional View and Exterior View of Internal Geometry in SolidWorks ${ }^{\circledR}$ Model of 24P DSC 


\subsection{STAR-CCM+ Model Mesh}

The complete CAD assembly developed in SolidWorks ${ }^{\circledR}$ was imported into STAR-CCM + . The geometry was then meshed into 43 separate regions connected by 117 interface boundaries, resulting in a single conformal volume mesh across all regions. The polyhedral volume mesh of the HSM-15 assembly contains 21,536,624 cells, 127,598,563 faces, and 106,295,728 vertices. Along each wall/fluid interface, the mesh contains a prism layer to improve the accuracy of the flow solution near the walls. The prism layer consists of orthogonal prismatic cells, two cells thick, adjacent to the wall boundaries.

Figure 3.1 shows an exterior view of the overall volume mesh of the HSM-15 assembly. The interior mesh, including the 24P DSC within HSM-15, is illustrated in Figure 3.2 with an axial slice along the central midplane of the structure. Figure 3.3 shows the mesh for a transverse slice through the module near the middle of the axial length of the DSC. Figure 3.4 merges the two planar slices, illustrating the detailed 3-D meshing of this system. The mesh within the 24P DSC and in the region of the airflow path around the DSC is highly resolved, to appropriately capture temperature and velocity gradients. In the concrete walls and in airflow regions far from the DSC, where gradients are less extreme, a coarser mesh is used, for computational efficiency.

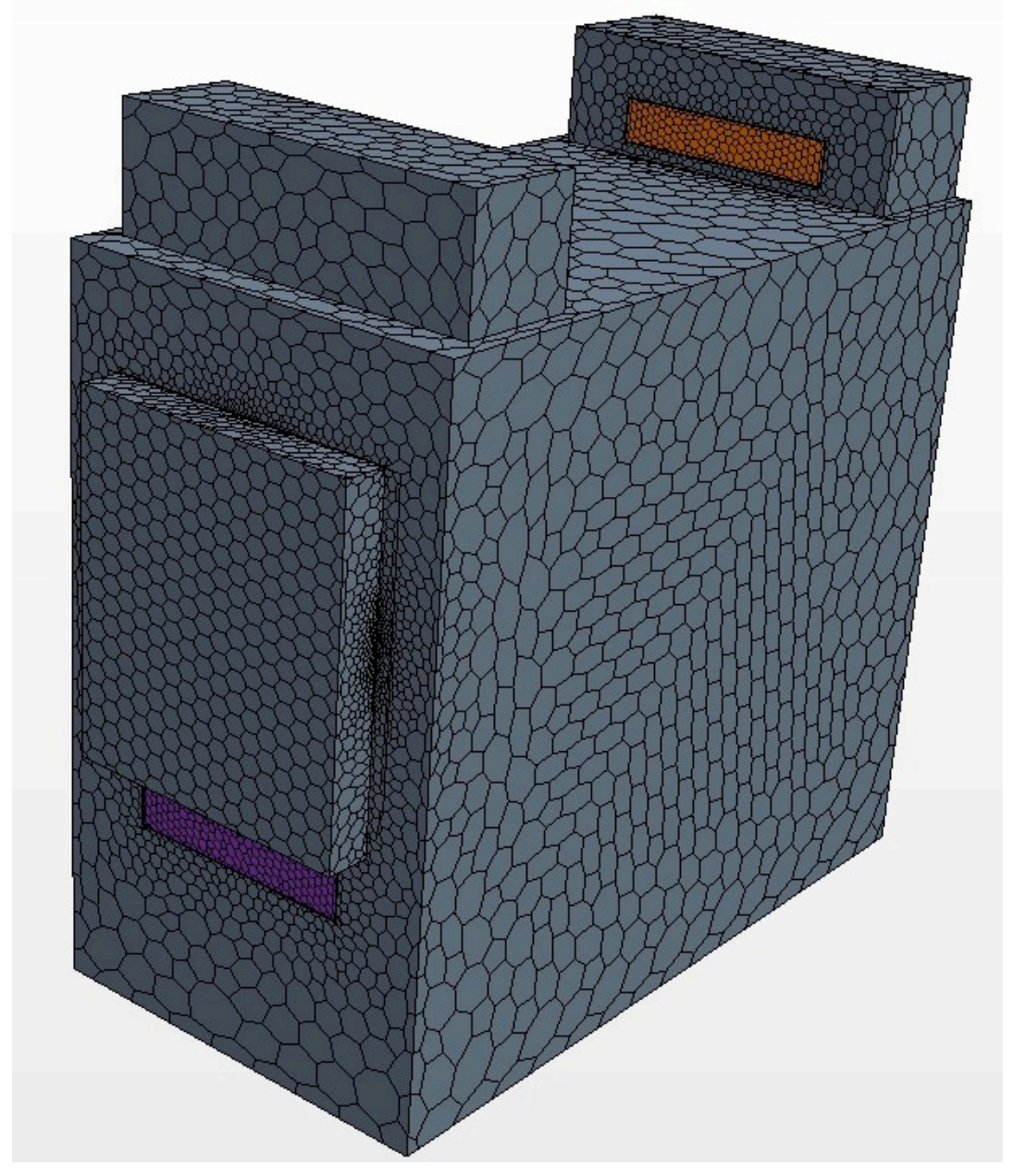

Figure 3.1. Volume Mesh of HSM-15 Assembly: Exterior View 


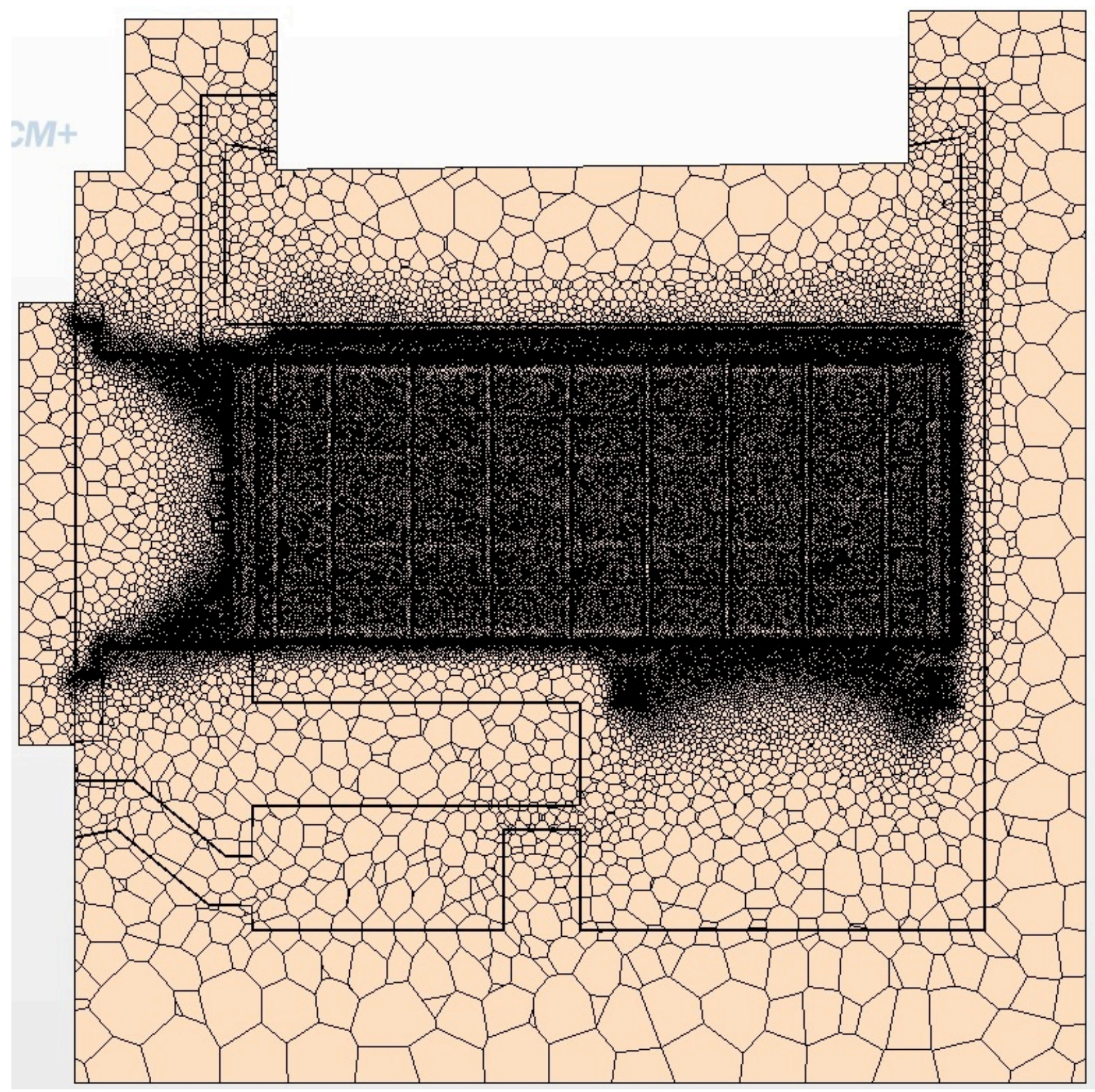

Figure 3.2. Planar Slice Through Centerline Showing Volume Mesh of HSM-15 and 24P DSC Model in Axial Direction 


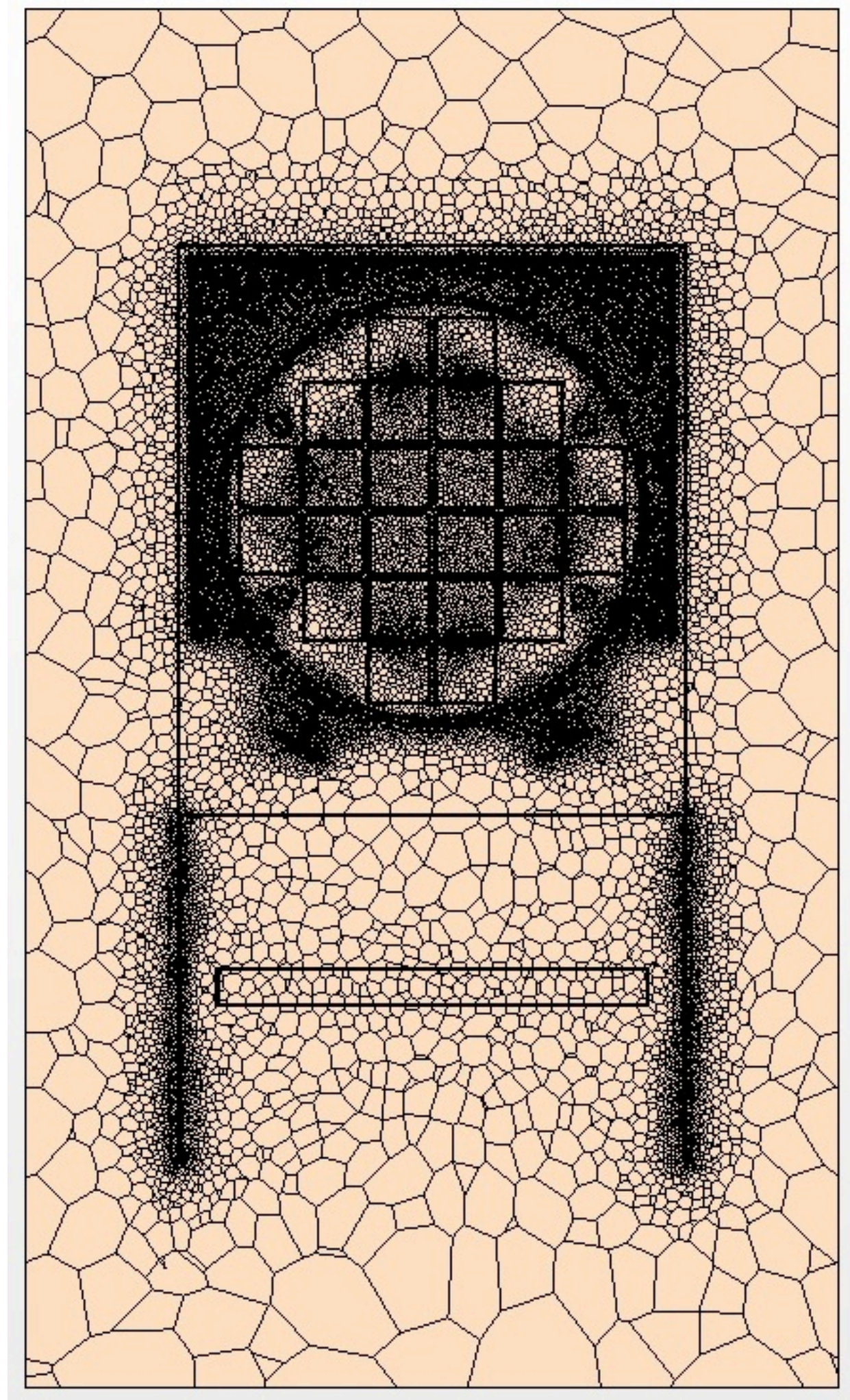

Figure 3.3. Planar Slice Through Mid-line Showing Volume Mesh of HSM-15 and 24P DSC Model in Transverse Direction 


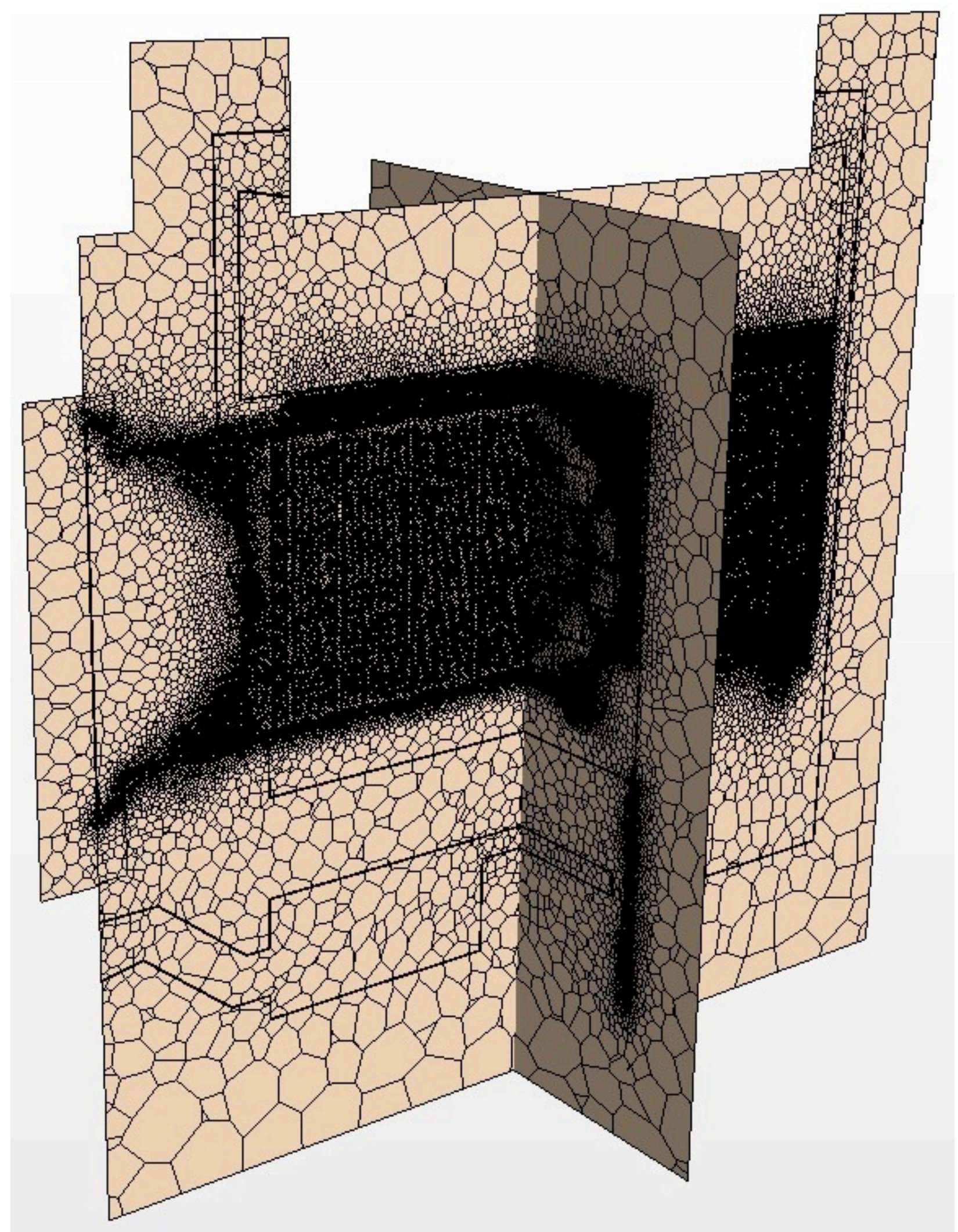

Figure 3.4. Merged Axial and Transverse Cross-sections, Illustrating Overall Volume Mesh of Internal Regions 


\subsection{STAR-CCM+ Model Materials}

The HSM-15 module consists mainly of concrete, with steel support components and stainless steel thermal shield plates. The 24P DSC contains the SNF assemblies and is back-filled with helium gas, but the canister (including its internal structures) is composed mainly of carbon steel and stainless steel. This relatively simple bill of materials list required defining only four solid material types within the STARCCM model for the solid regions of the mesh; concrete, carbon steel, stainless steel, and a homogeneous material representing the fuel assemblies. For the fluid regions of the mesh, air properties were specified for the regions defining the air flow path through the system. Helium properties were specified for the canister fill gas.

Appendix A lists the material properties assumed for all materials represented in the model, along with a mapping of material type to the solid regions of the mesh. Properties from the STAR-CCM+ materials library were used for concrete, carbon steel, stainless steel, and air. Properties for helium were specified in a temperature-dependent input table. The fuel assemblies were represented using a homogeneous k-effective model for CE14x14 fuel, as described in Section 4.1.

\subsection{Fuel Effective Conductivity Model}

The 24P DSC in HSM-15 contains 24 CE14x14 spent fuel assemblies discharged from the Calvert Cliffs plant at the end of various cycles from 1982 to 1987. In the STAR-CCM+ model of this system, the active fuel length of each fuel assembly was modeled using a homogeneous effective conductivity representing CE 14x14 fuel. The effective conductivity is determined using the modeling approach typically used in spent fuel thermal evaluations (Bahney and Lotz, 1996). The effective thermal conductivity used in this analysis for the 24P DSC in HSM-15 was developed for CE14x14 fuel and is listed in Appendix A.

The effective conductivity model is by design conservative, and therefore is not entirely congruent with the overall approach of developing a realistic model of the storage system. However, for CFD packages such as STAR-CCM+, the size of the model needed to represent the complex geometry of a multi-assembly DSC exceeds the capability of current computer platforms. For this reason, planned future work on this project includes developing a detailed, best-estimate model of the DSC using the COBRA-SFS code (Michener, et al., 1995), to obtain realistic estimates of canister internal temperatures, including rod by rod fuel cladding temperatures and temperature distributions. Experience suggests that for steady-state calculations, the peak cladding temperatures can be expected to be within 10 degrees-F ( $\sim 6$ degrees-C) of the values predicted with the k-effective model. The radial temperature distribution in the fuel, however, may show significant differences, particularly in the edge region near the basket walls, which can affect the predicted temperatures for the basket region.

\subsection{Surface Emissivities}

Surface-to-surface thermal radiation within the HSM cavity and within the DSC is included in the heat transfer evaluations with the STAR-CCM+ model. Table 4.1 lists the emissivity values for the solid surfaces in the model. These are typical values for stainless steel, carbon steel, and concrete. Sensitivity studies on the effect of emissivity values on temperatures and temperature distributions are beyond the 
scope of the current study. However, it is expected that this will be investigated in future work, since surface conditions of storage module components may differ from typical ranges, and also may change over the period of extended storage.

Table 4.1. Emissivity Values for Radiation Heat Transfer

\begin{tabular}{|c|c|}
\hline Material & Emissivity \\
\hline Carbon Steel & 0.65 \\
\hline Concrete & 0.8 \\
\hline Stainless Steel & 0.46 \\
\hline
\end{tabular}

A typical value of 0.8 for zircaloy cladding was assumed for the emissivity of the fuel rod surfaces in the development of the effective conductivity model (see Section 4.1) for the homogeneous representation of the fuel assemblies. Future work with detailed modeling of the fuel assemblies using the COBRA-SFS code will include sensitivity studies on this parameter, as well as investigations of the effect of surface emissivity of the steel components within the DSC.

\subsection{Fluid Models}

There are two fluid continua in the STAR-CCM+ model, helium in the DSC and air moving through the module between inlet and outlet vents. Each is treated separately with independent flow model assumptions and properties. As stated above, molecular transport properties for the helium and air are listed in Appendix A. The helium within the DSC is modeled as a laminar flow and the cooling airflow is modeled as turbulent. Simulation results support these model assumptions.

The turbulence model selected for the cooling air flow is the STAR-CCM+ implementation of SST (Menter) K-Omega with all default parameters and flexible (all-y+) treatment for wall boundary conditions. The value of turbulent Prandtl number was also left at its default value. 


\subsection{Boundary Conditions}

This section discusses boundary conditions primiarily in terms of the HSM15 model. Section 8 contains additional discussion of boundary conditions specific to the HSM1 model. External boundary conditions were used to define the environment seen by the HSM-15 model. These are described in Section 5.1. Internal boundary conditions were used to define the decay heat source within the DSC, and to represent specific thermal characteristics of the HSM-15 and DSC internal components. Internal thermal boundaries are discussed in Section 5.2. The decay heat load distribution in the fuel assemblies within the DSC is described in Section 5.3.

\subsection{External Boundaries}

The external environment of the HSM-15 model assembly consists of the external ambient air and the adjacent modules on either side and behind this module in the 2x6 array of the 12-module block. The adjacent modules were loaded at different times, relative to the loading date of November 1996 for HSM15; the module behind HSM-15 was loaded in January 1994, the module on one side was loaded in October 1996, and the one on the other side was loaded in March 1998. All three of these modules have slightly lower decay heat loads than HSM-15, and are at slightly different values.

As a modeling simplification, it was assumed that HSM-15 could be treated as having adiabatic conditions on the back and side walls. That is, it is assumed that there is no significant heat loss or gain through these walls. This is a reasonable assumption, given that the thermal behavior of this system is dominated by the vertical airflow through the module cavity and around the DSC outer surface. Sensitivity studies of the effect of non-adiabatic side boundary walls are beyond the scope of the current study, but are recommended for future work, and for investigations of thermal performance of the end module in an ISFSI array, in which the outer surface of one side wall is exposed to ambient.

Since vertical airflow due to natural convection driven by the 'chimney effect' of the thermal load of the DSC within the module is the main means of heat removal in this system, the most significant boundary condition is the temperature of the ambient air surrounding the module. Figure 5.1 shows monthly average maximum and minimum temperatures in the region of the Calvert Cliffs Nuclear Power Station since 1895, over a span of more than 100 years, obtained from the National Oceanic and Atmospheric Administration (NOAA) historical climatology data (U. S. HCN, 2000). The data in this plot show that the mean monthly temperatures (maxima and minima) have been extremely consistent over the past 100 years, with maxima around $80-85^{\circ} \mathrm{F}\left(27-29^{\circ} \mathrm{C}\right)$, minima around $25^{\circ} \mathrm{F}\left(-4^{\circ} \mathrm{C}\right)$, and a mean yearly average of about $56^{\circ} \mathrm{F}\left(13^{\circ} \mathrm{C}\right)$. This suggests that weather data from any given one-year period can be taken as reasonably representative of the ambient environment seen by the storage modules over their approximately 16 years in service at the Calvert Cliffs ISFSI. 


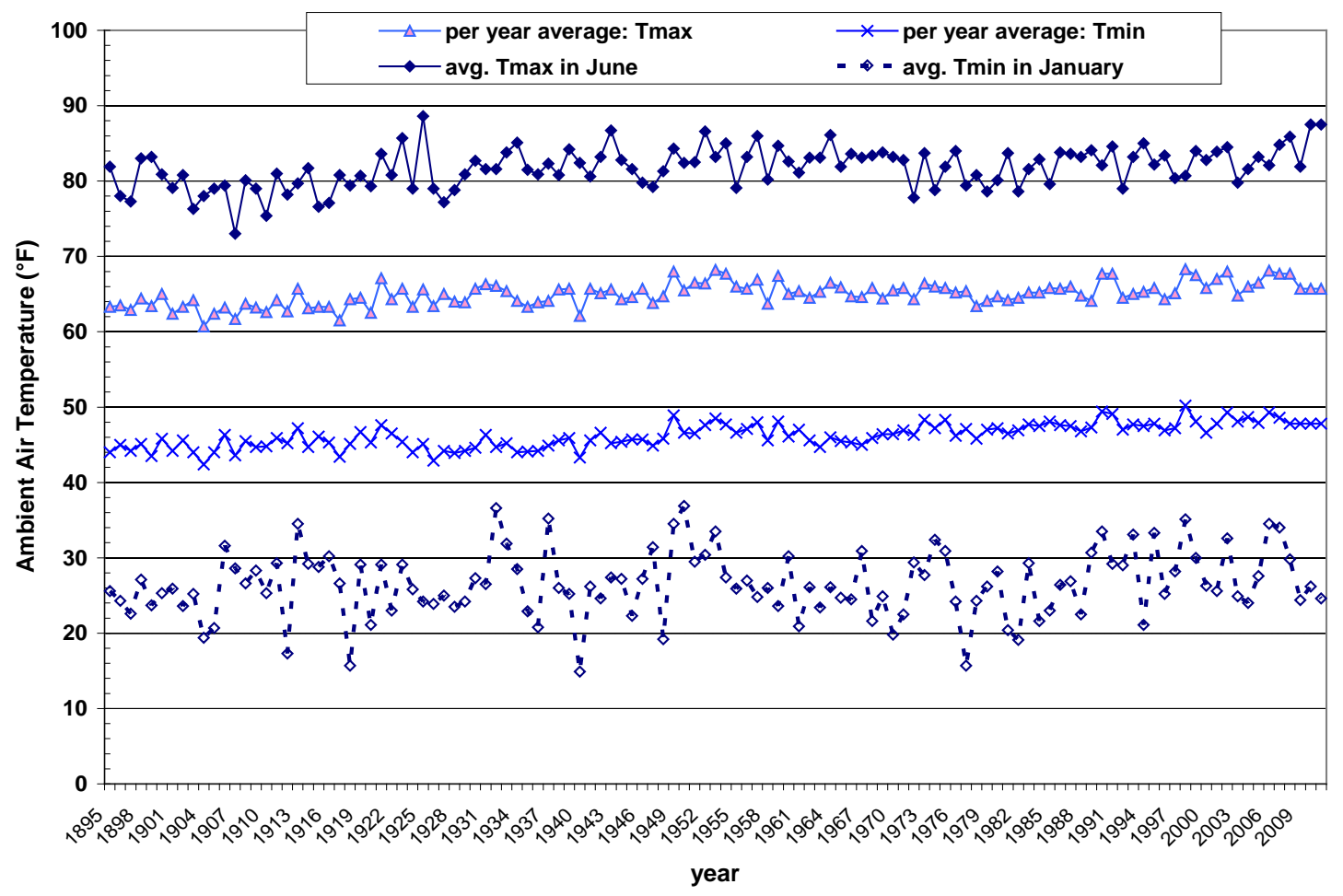

Figure 5.1. Historical Weather Data for Calvert Cliffs Region: Annual Maximum and Minimum Monthly Average Temperatures over the Past 100 Years

The average diurnal temperature swing derived from temperature measurements taken at the Calvert Cliffs ISFSI over the entire year in 2010 is shown in Figure 5.2, and compared to the averages based on the NOAA historical temperature data. This plot shows that the average diurnal temperature swing at the ISFSI is less than 10 degrees Fahrenheit ( $\sim 6$ degrees Celsius), and the average annual temperature in 2010 was $58^{\circ} \mathrm{F}\left(14^{\circ} \mathrm{C}\right)$, compared to the annual average of $56^{\circ} \mathrm{F}\left(13^{\circ} \mathrm{C}\right)$ from the NOAA historical data. It was therefore assumed that the value of $58^{\circ} \mathrm{F}\left(14^{\circ} \mathrm{C}\right)$ is a reasonable estimate of average ambient temperature at the Calvert Cliffs ISFSI from November 1996 to June 2012. 


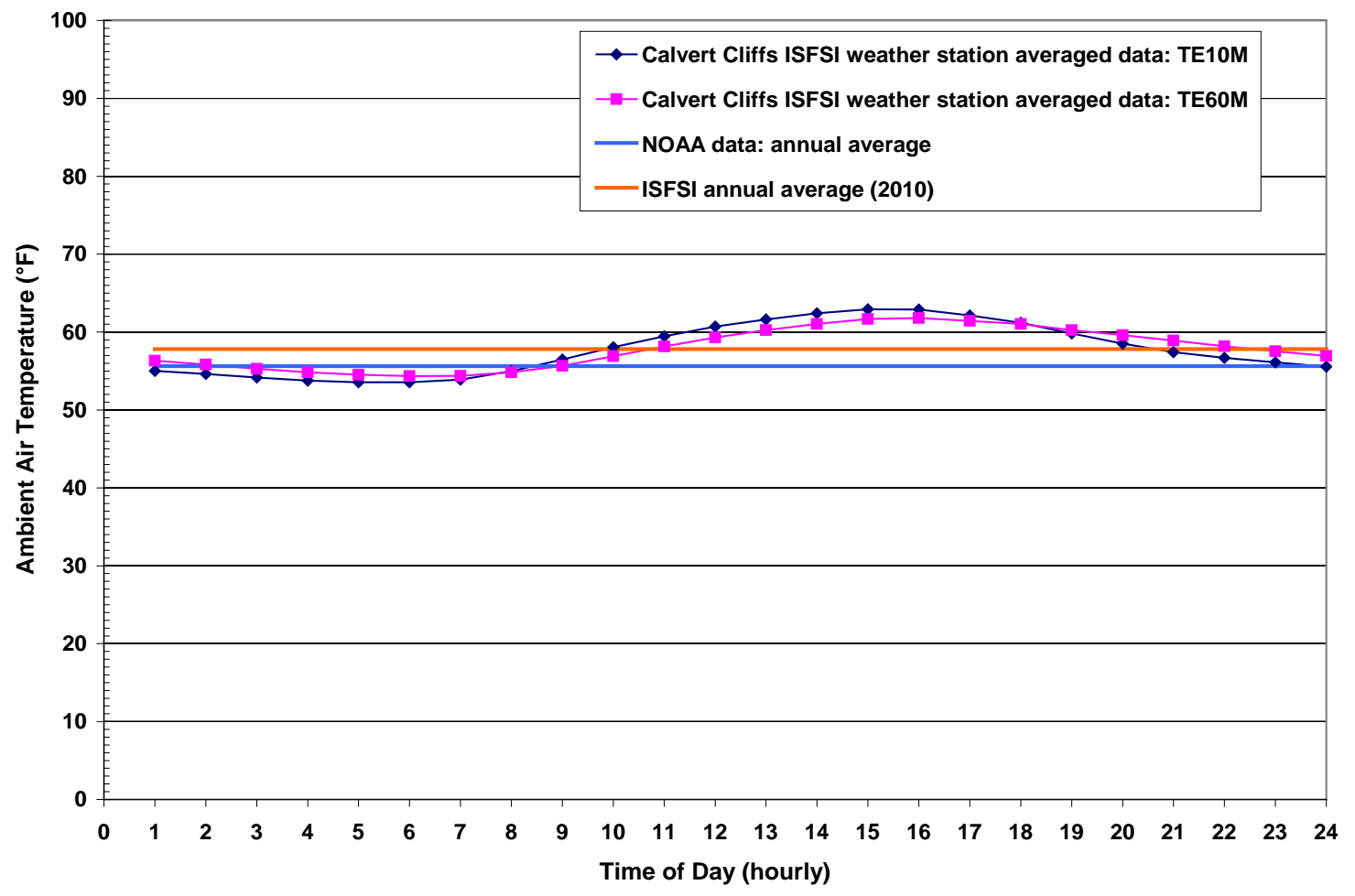

Figure 5.2. Annual Average Diurnal Temperature Variation at Calvert Cliffs ISFSI (Based on Temperature Data from 2010)

The average annual ambient air temperature of $58^{\circ} \mathrm{F}\left(14^{\circ} \mathrm{C}\right)$ was used as the base case for steady-state calculations of the temperature distribution within HSM-15 and its 24P DSC. The system is evaluated at steady-state, and with the annual average temperature for external ambient. This approach is based on the assumption that the thermal inertia of the system is large enough that seasonal variations in ambient temperature do not significantly affect the peak temperatures and temperature distributions within the system. As a bounding sensitivity study on this assumption, three other cases were also evaluated, varying the ambient air temperature over the maximum range consistent with the available weather data. Table 5.1 lists the range of high and low average ambient temperatures evaluated.

Table 5.1. Ambient Air Temperature Range Evaluated

\begin{tabular}{|c|c|}
\hline Season & $\begin{array}{c}\text { Ambient air } \\
\text { temperature }\end{array}$ \\
\hline annual average (base case) & $58^{\circ} \mathrm{F}\left(14^{\circ} \mathrm{C}\right)$ \\
\hline June average & $72^{\circ} \mathrm{F}\left(22^{\circ} \mathrm{C}\right)$ \\
\hline July average & $77^{\circ} \mathrm{F}\left(25^{\circ} \mathrm{C}\right)$ \\
\hline January average & $35^{\circ} \mathrm{F}\left(2^{\circ} \mathrm{C}\right)$ \\
\hline
\end{tabular}


These cases are bounding in that the steady-state solution allows the system to come into equilibrium with the minimum and maximum seasonal change in average ambient temperature. The results of the June, July, and January cases provide an estimate of the possible range of temperature variation for the system in comparison to the temperatures predicted for the annual average ambient temperature.

In the STAR-CCM+ calculations, the specified ambient temperature for the external air is assumed to represent an effectively infinite reservoir from which air can be drawn by the pressure gradient developed in response to the thermal load within the module. The boundary condition is represented with ambient pressure and temperature at the location of the inlet vent. The single inlet vent on the front face of the module and the two exit vents at the top of the module were treated as pressure boundaries. STAR$\mathrm{CCM}+$ internally accounts for the difference in static pressure, based on the air temperature and density, due to the elevation difference between the inlet and outlet boundaries. With these external boundary conditions, STAR-CCM+ solves for the air flow rate through the system.

\subsubsection{Concrete Base}

The external base of the HSM-15 model includes the 36-inch thick concrete pad, which constitutes a conduction path to the ground. The thermal boundary condition on the external surface of the base of the module was specified as equivalent to a conduction path through 6 feet of soil to a boundary temperature of $60^{\circ} \mathrm{F}\left(16^{\circ} \mathrm{C}\right)$. This is a typical approach for determining the heat loss through underlying soil to the constant sink temperature of the earth, assumed to be at $60^{\circ} \mathrm{F}\left(16^{\circ} \mathrm{C}\right)$. The underlying soil was assumed to have a typical conductivity of $0.52 \mathrm{~W} / \mathrm{m}-\mathrm{K}$ (Incropera, et al., 2007).

\subsubsection{External Convection Boundaries}

A convection boundary was specified for the top and front surfaces of the concrete region of the model, to account for convection heat transfer to ambient air from the exposed surfaces of the module. A heat transfer coefficient is defined at the convection boundaries, based on correlations for free convection from vertical flat plates and horizontal surfaces to surrounding still air (Guyer, 1989). The natural convection correlations used to calculate the convection coefficients are presented in Appendix B. Evaluation of the effect of moving air due to wind conditions is beyond the scope of the current study.

Solar heat loads are applied at the outer surfaces (top and front face) of the module. A direct solar flux vector with a specified magnitude and direction is applied externally to the model. The resulting average outer surface heat flux due to sunlight for each horizontal and vertical surface was approximately equal to the solar insolation loads prescribed in regulations for packaging and transportation of radioactive material (10 CFR 71). The solar absorptivity of the external concrete surfaces is assumed to be equal to the surface emissivity. The specified surface emissivity is also used in the calculation of external thermal radiation to the environment.

\subsection{Resistance Boundaries}

A conservative simplifying assumption typically used in safety analysis of dry storage systems is to neglect conduction between components that could be in physical contact in the system, particularly within the DSC. In the model of the 24P DSC within the HSM-15, contact was assumed between 
components that could reasonably be expected to be in physical contact with the DSC in a horizontal orientation. Contact resistance boundaries were specified at the following interfaces;

- fuel/guide sleeves resting on the spacer disks

- spacer rod ends resting against the inner face of the bottom end cap

- fuel assembly region end resting against the inner face of the bottom end cap

- spacer disk to DSC

- external support rails to DSC.

The effect of physical contact between the fuel assembly hardware and the guide sleeves was neglected, since it cannot readily be represented with the simplification of the homogeneous representation of the fuel region using the effective conductivity model, described in Section 4.1. Evaluation of this potential heat transfer path could be included in future work with a detailed bestestimate COBRA-SFS model of the fuel assemblies within the DSC, but it would not be expected to have a significant effect on overall peak temperatures or temperature distributions within the DSC .

As a first approximation, typical values of contact resistance were defined for the various components of the model. For the DSC resting on the support rails, the interface was represented with a constant contact conductance value of 5.28E-4 $\mathrm{m}^{2}-\mathrm{K} / \mathrm{W}$ for 304 stainless steel surfaces (Holman, 1997). This is a slightly low estimate, since the support rails are actually carbon steel, but would not be expected to have a large effect on DSC surface temperatures or temperature distributions. The main mode of heat removal from the DSC is convection to the air, with only minor losses due to conduction to the support rails.

All other contact resistance boundaries included in the model accounted for gaps at interfaces due to estimated fit tolerances between components. The spacer disk-to-DSC contact resistance assumed a uniform gap between cylindrical surfaces and was calculated based on the following equation (Incropera, et al., 2007):

$$
R=\frac{\ln \left(r_{2} / r_{1}\right) A}{2 \pi L k}
$$

where

$\mathrm{R}=$ contact resistance $\left(\mathrm{m}^{2}-\mathrm{K} / \mathrm{W}\right)$

$\mathrm{L}=$ gap width (m)

$\mathrm{k}=$ thermal conductivity of the fluid $(\mathrm{W} / \mathrm{m}-\mathrm{K})$

$\mathrm{A}=$ area normal to the direction of heat transfer $\left(\mathrm{m}^{2}\right)$

$\mathrm{r} 1=$ inner surface radius $(\mathrm{m})$

$\mathrm{r} 2=$ outer surface radius $(\mathrm{m})$

In reality, the gap between the spacer disks and the inner surface of the DSC varies with radial location around the circumference. There is direct contact at the bottom (i.e., zero gap) over an arc determined by the geometry of the circular disk within the cylindrical DSC shell. The gap gradually increases with distance from the bottom, around the rim of the disk, with the largest gap width at the top of the horizontal cylindrical DSC shell. The uniform gap used in the current study represents a simplified base case. Appendix C presents a preliminary sensitivity study on this parameter, and future work will 
revisit this assumption to determine a more physically realistic approach to determining the gap variation and contact resistance relationship for the spacer disks and DSC.

The contact resistances at the remaining interfaces were calculated based on the following equation (Incropera, et al., 2007):

$$
R=\frac{L}{k}
$$

where

$R=$ contact resistance $\left(\mathrm{m}^{2}-\mathrm{K} / \mathrm{W}\right)$

$L=$ gap width (m)

$k=$ thermal conductivity of the fluid $(\mathrm{W} / \mathrm{m}-\mathrm{K})$

The gap width was calculated based on the difference between components at their nominal tolerance values.

To account for the stainless steel guide sleeves, which were not physically represented in the model, the contact resistance at the fuel interface was calculated using Equation (4.2), with $L$ representing the thickness of the guide sleeve wall and $k$ the thermal conductivity of stainless steel. At interfaces that included tolerance gaps, such as the fuel/spacer disk interface, the total contact resistance was calculated by summing the resistance due to the guide sleeve and an appropriate nominal tolerance gap between the guide sleeve and spacer disk.

\subsection{Fuel Assembly Loading}

A separate decay heat load was defined for each of the 24 active fuel regions representing the $24 \mathrm{CE}$ $14 \times 14$ assemblies within the DSC, using canister loading data ${ }^{1}$ from the Calvert Cliffs ISFSI. Based on the discharge date and final burnup of each assembly, the individual decay heat load for each fuel assembly was determined with ORIGEN-ARP (Gauld, et al., 2009) for the time of loading into the DSC (November 1996) and extended to the June 2012 inspection timeframe. Figure 5.3 shows the identification numbers and locations of the 24 fuel assemblies in this DSC. Assemblies with similar decay heat loads are shown in the same color.

Table 5.2 lists the individual assembly decay heat loads calculated as of June 2012. The total decay heat load for the DSC (all 24 fuel assemblies) was calculated as $10.8 \mathrm{~kW}$ at the time of loading, and is projected to be approximately $7.6 \mathrm{~kW}$ as of June 2012. The decay heat load was applied as an energy source over the active fuel length within each fuel region as a volumetric heat load, with each value listed in Table 5.2 divided by the volume of a single active fuel region.

\footnotetext{
${ }^{1}$ Provided by John Massari of Constellation Energy Nuclear Group, Nuclear Analysis Supervisor at the Calvert Cliffs Nuclear Power Station.
} 


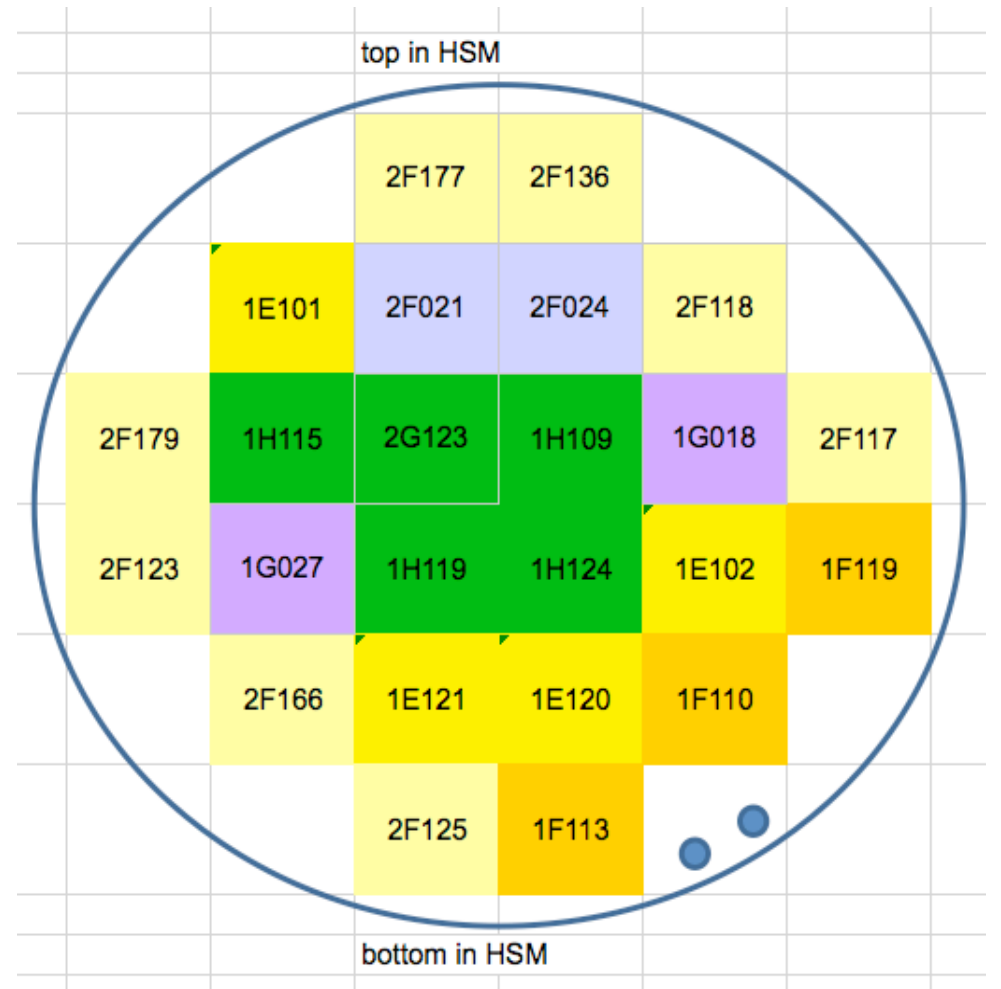

Figure 5.3. Fuel Assembly Loading and Identification Numbers

Table 5.2. Fuel Assembly Decay Heat Loads for DSC in HSM-15 as of June 2012

\begin{tabular}{|c|c|}
\hline $\begin{array}{c}\text { Fuel } \\
\text { Assembly } \\
\text { ID }\end{array}$ & $\begin{array}{c}\text { Heat } \\
\text { Load } \\
(\mathrm{kW})\end{array}$ \\
\hline $2 \mathrm{G} 123$ & 0.427 \\
\hline $1 \mathrm{H} 109$ & 0.407 \\
\hline $1 \mathrm{H} 115$ & 0.406 \\
\hline $1 \mathrm{H} 119$ & 0.408 \\
\hline $1 \mathrm{H} 124$ & 0.407 \\
\hline $2 \mathrm{~F} 021$ & 0.385 \\
\hline $2 \mathrm{~F} 024$ & 0.385 \\
\hline $1 \mathrm{E} 101$ & 0.301 \\
\hline $1 \mathrm{E} 102$ & 0.301 \\
\hline $1 \mathrm{E} 120$ & 0.302 \\
\hline $1 \mathrm{E} 121$ & 0.302 \\
\hline $1 \mathrm{G} 018$ & 0.327 \\
\hline $1 \mathrm{G} 027$ & 0.340 \\
\hline $2 \mathrm{~F} 117$ & 0.285 \\
\hline $2 \mathrm{~F} 118$ & 0.286 \\
\hline $2 \mathrm{~F} 123$ & 0.285 \\
\hline $2 \mathrm{~F} 125$ & 0.274 \\
\hline $2 \mathrm{~F} 136$ & 0.291 \\
\hline
\end{tabular}




\begin{tabular}{|c|c|}
\hline $\begin{array}{c}\text { Fuel } \\
\text { Assembly } \\
\text { ID }\end{array}$ & $\begin{array}{c}\text { Heat } \\
\text { Load } \\
(\mathrm{kW})\end{array}$ \\
\hline $2 \mathrm{~F} 166$ & 0.272 \\
\hline $2 \mathrm{~F} 177$ & 0.272 \\
\hline $2 \mathrm{~F} 179$ & 0.290 \\
\hline $1 \mathrm{~F} 110$ & 0.225 \\
\hline $1 \mathrm{~F} 113$ & 0.225 \\
\hline $1 \mathrm{~F} 119$ & 0.232 \\
\hline
\end{tabular}

The volumetric heat generation rate based on decay heat load at the axial position of each cell within the active fuel region was multiplied by an axial peaking factor. Initial pre-test calculations were performed using a bounding profile for low-burnup PWR fuel (DOE/RW-0472, 1998). This bounding profile was derived from a database of profiles for fuel assemblies having burnup values ranging from 26 to $44 \mathrm{GWd} / \mathrm{MTU}$, with an average burnup of $35 \mathrm{GWd} / \mathrm{MTU}$. Post-test evaluations used a profile based on representative burnup evaluations of CE14x14 fuel performed at Calvert Cliffs. This axial profile, shown in Figure 5.4, is similar to the bounding curve for low burn-up fuel.

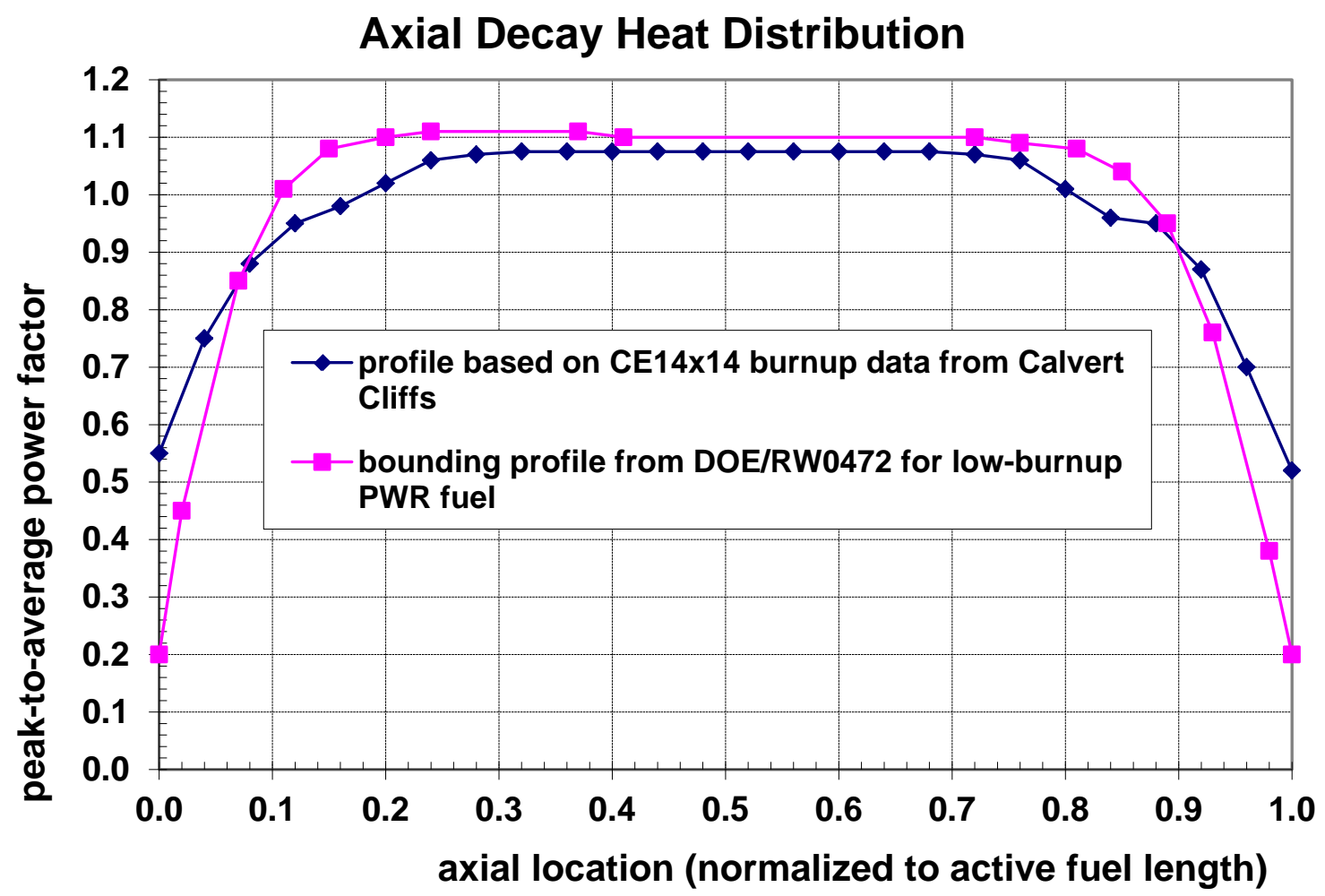

Figure 5.4. Burn-up Profiles from Calvert Cliffs CE14x14 Fuel ${ }^{2}$ Compared to Bounding Axial Peaking Factor for Low Burnup ( $<35 \mathrm{GWd} / \mathrm{MTU}$ (average)) Spent Fuel (DOE/RW-0472, 1998)

\footnotetext{
${ }^{2}$ Axial burnup profile data was provided by John Massari of Calvert Cliffs. The profile shown is representative of axial burnup profiles obtained in a 2006 study at Calvert Cliffs to determine thermal and radiological source terms for CE standard 14x14 fuel assemblies then in the spent fuel pool with burnup ranges up to52 GWd/MTU.
} 


\subsection{STAR-CCM+ Solver}

The STAR-CCM+ segregated solver was used for this study. It solves the flow equations for velocity and pressure in a segregated, or uncoupled, manner. The relationship between the momentum and continuity equations is achieved with a predictor-corrector method (CD-Adapco, 2012). An alternative to the segregated solver is a coupled solver that solves the conservation equations simultaneously using a time-marching approach. The segregated solver requires less computational resources and was used as a first step for this model. Convergence issues with the coupled solver are being investigated by CDAdapco, and it may be possible for future work to include running the model with the coupled solver. This is expected to add further confidence to the results obtained with the segregated solver. Default STAR-CCM+ solver parameters were used in all cases, with the exception of the velocity solution underrelaxation, which was reduced to 0.1 . Default spatial differencing (second order) was also used. 



\subsection{Thermal Modeling Results and Discussion}

As discussed above in Section 5, the base case for thermal evaluation of the 24P DSC in HSM-15 assumed an ambient temperature of $58^{\circ} \mathrm{F}\left(14^{\circ} \mathrm{C}\right)$, corresponding to the estimated annual ambient temperature at the Calvert Cliffs ISFSI over the operational life of this module. Bounding sensitivity studies on the effect of ambient air temperature were performed for two cases; a 'summer case' at $77^{\circ} \mathrm{F}$ $\left(25^{\circ} \mathrm{C}\right)$ based on average temperatures in July, and a 'winter case' at $35^{\circ} \mathrm{F}\left(2^{\circ} \mathrm{C}\right)$, based on average temperatures in January. An additional case was included at $72^{\circ} \mathrm{F}\left(22^{\circ} \mathrm{C}\right)$, based on the average temperature in June, to correspond with the planned time-frame of testing to obtain temperature measurements in the system.

Preliminary results for the different cases were obtained using the segregated solver in STAR-CCM+. Peak component temperatures for the four cases evaluated are summarized in Table 7.1. This table also lists the minimum temperature on each component, since this is also of interest for some materials evaluations for long-term storage conditions.

Table 7.1. Component Maximum and Minimum Temperatures: Base Case (HSM-15)

\begin{tabular}{|c|c|c|c|c|c|}
\hline & $\begin{array}{c}\text { ambient air } \\
\text { temperature } \\
\left({ }^{\circ} \mathrm{F}\left({ }^{\circ} \mathrm{C}\right)\right)\end{array}$ & $\begin{array}{c}\text { Concrete } \\
\text { temperature } \\
\left({ }^{\circ} \mathrm{F}\left({ }^{\circ} \mathrm{C}\right)\right)\end{array}$ & $\begin{array}{c}\text { DSC Shell } \\
\text { temperature } \\
\left({ }^{\circ} \mathrm{F}\left({ }^{\circ} \mathrm{C}\right)\right)\end{array}$ & $\begin{array}{c}\text { Fuel } \\
\text { temperature } \\
\left({ }^{\circ} \mathrm{F}\left({ }^{\circ} \mathrm{C}\right)\right)\end{array}$ & $\begin{array}{c}\text { Heat Shield } \\
\text { temperature } \\
\left({ }^{\circ} \mathrm{F}\left({ }^{\circ} \mathrm{C}\right)\right)\end{array}$ \\
\hline $\begin{array}{l}\text { Base Case } \\
\text { (Max.) }\end{array}$ & \multirow{2}{*}{$58(14)$} & $123(51)$ & $256(124)$ & $382(194)$ & $145(63)$ \\
\hline $\begin{array}{l}\text { Base Case } \\
\text { (Min.) }\end{array}$ & & $58(14)$ & $83(28)$ & 103 (39) & 66 (19) \\
\hline $\begin{array}{l}\text { June Case } \\
\text { (Max.) }\end{array}$ & \multirow[b]{2}{*}{$72(22)$} & 139 (59) & $267(131)$ & 397 (203) & $160(71)$ \\
\hline $\begin{array}{l}\text { June Case } \\
\text { (Min.) }\end{array}$ & & $72(22)$ & $97(36)$ & $118(48)$ & $79(26)$ \\
\hline $\begin{array}{l}\text { Summer Case } \\
\text { (Max.) }\end{array}$ & \multirow{2}{*}{$77(25)$} & $145(63)$ & 278 (137) & 402 (206) & $166(74)$ \\
\hline $\begin{array}{l}\text { Summer Case } \\
\text { (Min.) }\end{array}$ & & $77(25)$ & 102 (39) & $122(50)$ & 85 (29) \\
\hline $\begin{array}{l}\text { Winter Case } \\
\text { (Max.) }\end{array}$ & \multirow[b]{2}{*}{$35(2)$} & $98(37)$ & $230(110)$ & $358(181)$ & $118(48)$ \\
\hline $\begin{array}{l}\text { Winter Case } \\
\text { (Min.) }\end{array}$ & & $35(2)$ & $61(16)$ & $80(27)$ & $41(5)$ \\
\hline
\end{tabular}


For the base case, with the decay heat load in the DSC in HSM-15 as of June 2012, the peak cladding temperature (PCT) for the fuel is predicted to be approximately $382^{\circ} \mathrm{F}\left(194^{\circ} \mathrm{C}\right)$, which is far below the long term storage limit of $752^{\circ} \mathrm{F}\left(400^{\circ} \mathrm{C}\right)$ for zircaloy cladding. The bounding variation in PCT due to changing ambient air boundary conditions relative to the annual average ambient temperature, is approximately $97 \%$ of the seasonal variation from annual ambient. This amounts to a typical maximum variation of about \pm 44 degrees Fahrenheit ( \pm 24 degrees Celsius) in the PCT.

For the decay heat load in the DSC in HSM-15 as of June 2012, the peak temperature on the DSC shell is $267^{\circ} \mathrm{F}\left(131^{\circ} \mathrm{C}\right)$, which is nearly 195 degrees $\mathrm{F}(108$ degrees Celsius) above ambient. For these calculations, which assume steady-state at each specified condition, the bounding seasonal variation in the peak DSC shell temperature exactly follows the change in ambient air boundary temperature. Since the DSC shell temperature is directly influenced by the temperature of the incoming air, the actual variation in this temperature is likely to be close to the bounding variation. Similarly, the minimum temperature on the DSC shell closely tracks the ambient air temperature, with a temperature difference of approximately 25 degrees $\mathrm{F}$ (14 degrees Celsius) relative to the temperature of the incoming air.

The maximum and minimum temperatures predicted for the heat shield surrounding the DSC follow the seasonal ambient changes, as shown by the results in Table 7.1. In reality, the steel heat shields probably do track the ambient changes relatively closely, even on a daily basis, since they have relatively limited thermal inertia, compared to the DSC and the concrete. The results shown for the concrete, however, are less likely to directly represent the actual change in peak temperatures with the seasonal variation in temperature. The peak concrete temperature is driven by the temperature of the heated air rising through the exit vents, but the large mass of concrete has a very large thermal inertia, which would tend to damp the rate of change of surface temperature in response to changing air temperature. The results for the annual average ambient (i.e., the base case) are more likely to be representative of the concrete temperatures year-round.

Regardless of the assumed ambient air temperature, the large differences between minimum and maximum temperatures on the components listed in Table 7.1 show that there are significant temperature gradients and non-uniform temperature distributions in this system. These distributions are at least as interesting as the magnitudes of the peak temperatures, particularly in evaluations of material performance within the system. The overall temperature and air flow distributions in the system are discussed in detail for the base case in Section 7.1. Potential effects of seasonal variation in average ambient temperature are presented in Section 7.2.

\subsection{Results for Base Case (HSM-15)}

Decay heat generation within the DSC heats the air inside the module, resulting in buoyancy flow upward around the DSC shell, toward the lower surface of the top heat shield. Bulk air flow through the module cavity is driven primarily by the difference in pressure inside and outside the module over the vertical distance between the module inlet and outlet vents. Figure 7.1 illustrates this complex flow due to natural convection and buoyancy with an axial slice through the midplane of the model for the base case, assuming an average annual ambient temperature of $58^{\circ} \mathrm{F}\left(14^{\circ} \mathrm{C}\right)$. Figure 7.2 shows the air temperature distribution in the same plane, and the corresponding temperature distribution in the module concrete. 


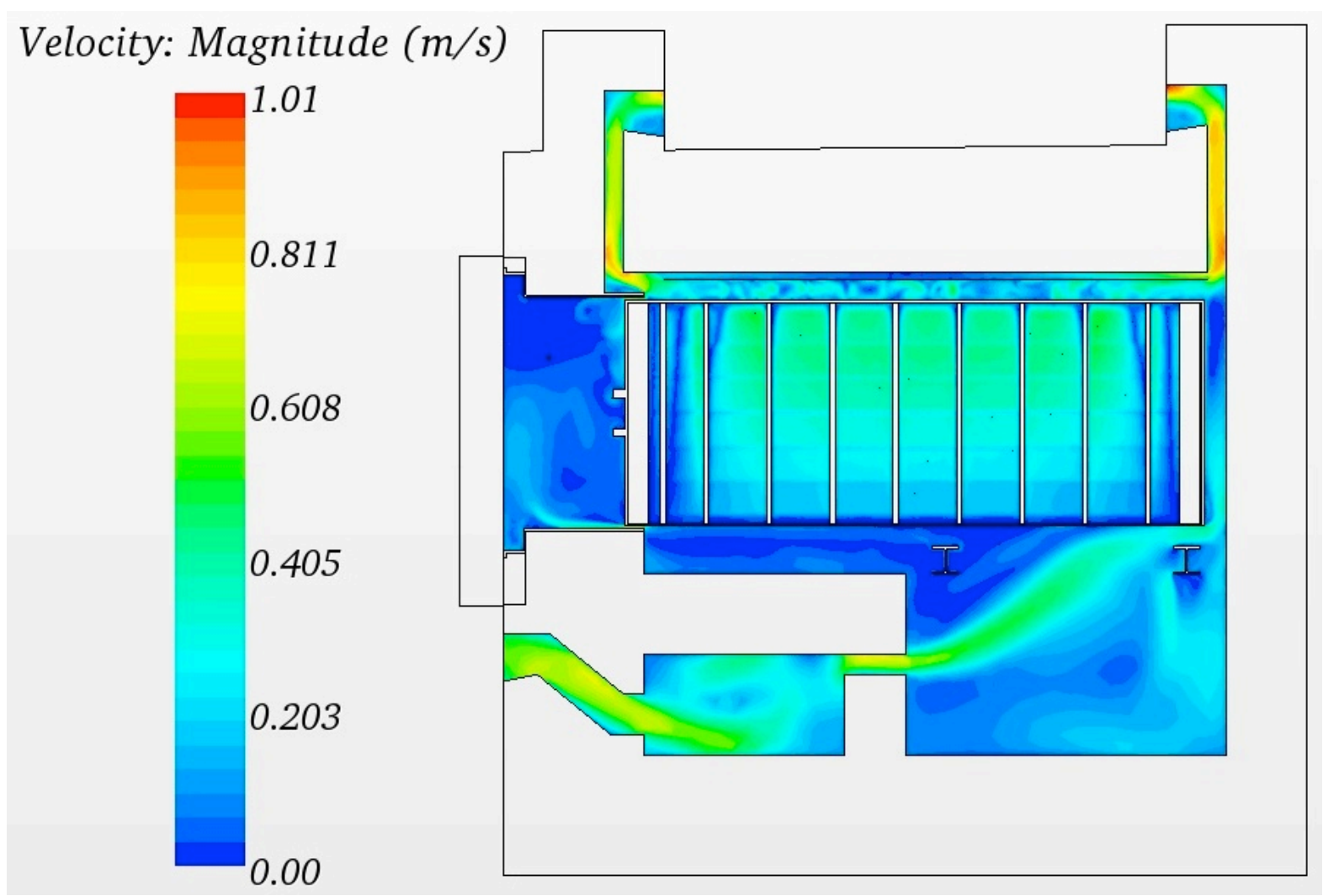

Figure 7.1. Velocity at Axial Midplane for Base Case (HSM-15) $-58^{\circ} \mathrm{F}\left(14^{\circ} \mathrm{C}\right)$ Ambient Air
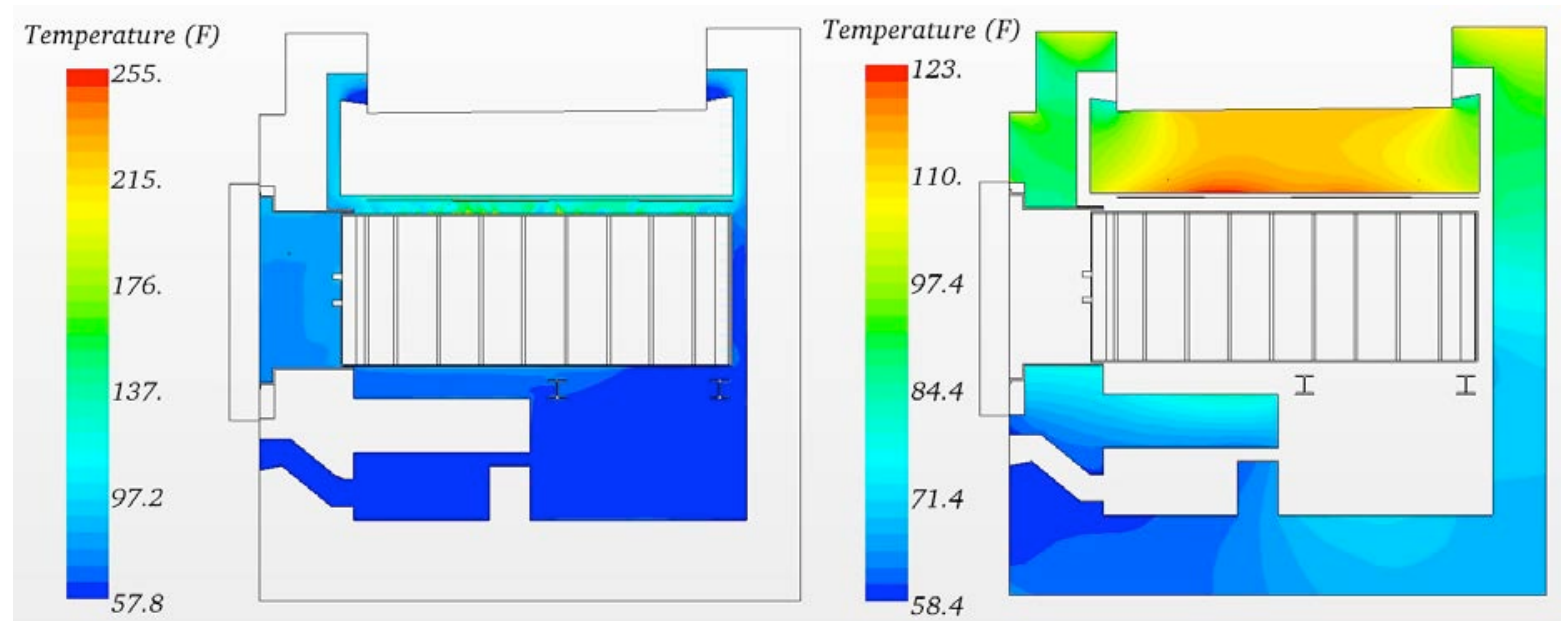

Figure 7.2. Air and Concrete Temperature Distributions at Axial Midplane for Base Case (HSM-15) $58^{\circ} \mathrm{F}\left(14^{\circ} \mathrm{C}\right)$ Ambient Air

As shown by the color contours in Figure 7.1, the highest velocities in the system are near the inlet and outlet, in the relatively restricted flow paths that constitute the inlet and outlet vents. The velocities are much lower in the large open regions below the DSC cavity, where the flow forms recirculation loops due in part to the temperature gradients in the concrete structure (see Figure 7.2). There is a significant dead zone of very low flow directly beneath the DSC, due mainly to the confining effects of the large I- 
beam rails supporting the DSC over the full axial length of the cavity. The space between the module door and the base of the DSC also show very low velocities, mainly because this region is essentially a blind cavity with no easy entrance or exit for flow and very little in the way of a temperature gradient in the surrounding walls.

The highest velocities within the cavity are around the upper half of the relatively hot DSC shell, where buoyancy effects most strongly augment the 'chimney effect' driving air through the system. The air rising near the top of the DSC shell is impeded by the heat shield, resulting in complex recirculation patterns above and below the top heat shield as air is drawn laterally toward the exit vents at either end of the cavity.

Figure 7.3 shows a contour plot of the DSC shell surface temperatures for the base case. This plot clearly shows the effect of the spacer disks as 'ribs' extending from the 'backbone' of the peak top center temperatures. In these calculations, this effect may be somewhat exaggerated by the assumption of uniform contact resistance around the periphery of the spacer disks (as discussed in Section 5.2). In reality, the spacer disks would be in intimidate contact with the DSC inner shell surface at the bottom of the horizontal DSC, due to the considerable weight of the fuel assemblies and support structure. The contact force would diminish with increasing circumferential distance from the bottom, and at some point a clearance gap would begin to open up, due to the difference between the disk diameter and the internal cavity diameter. The post-test evaluations included a sensitivity study on the effect of this modeling simplification. The results are presented in Appendix $C$, and show that circumferential variation in this heat transfer path has a relatively minor effect on component temperatures. 


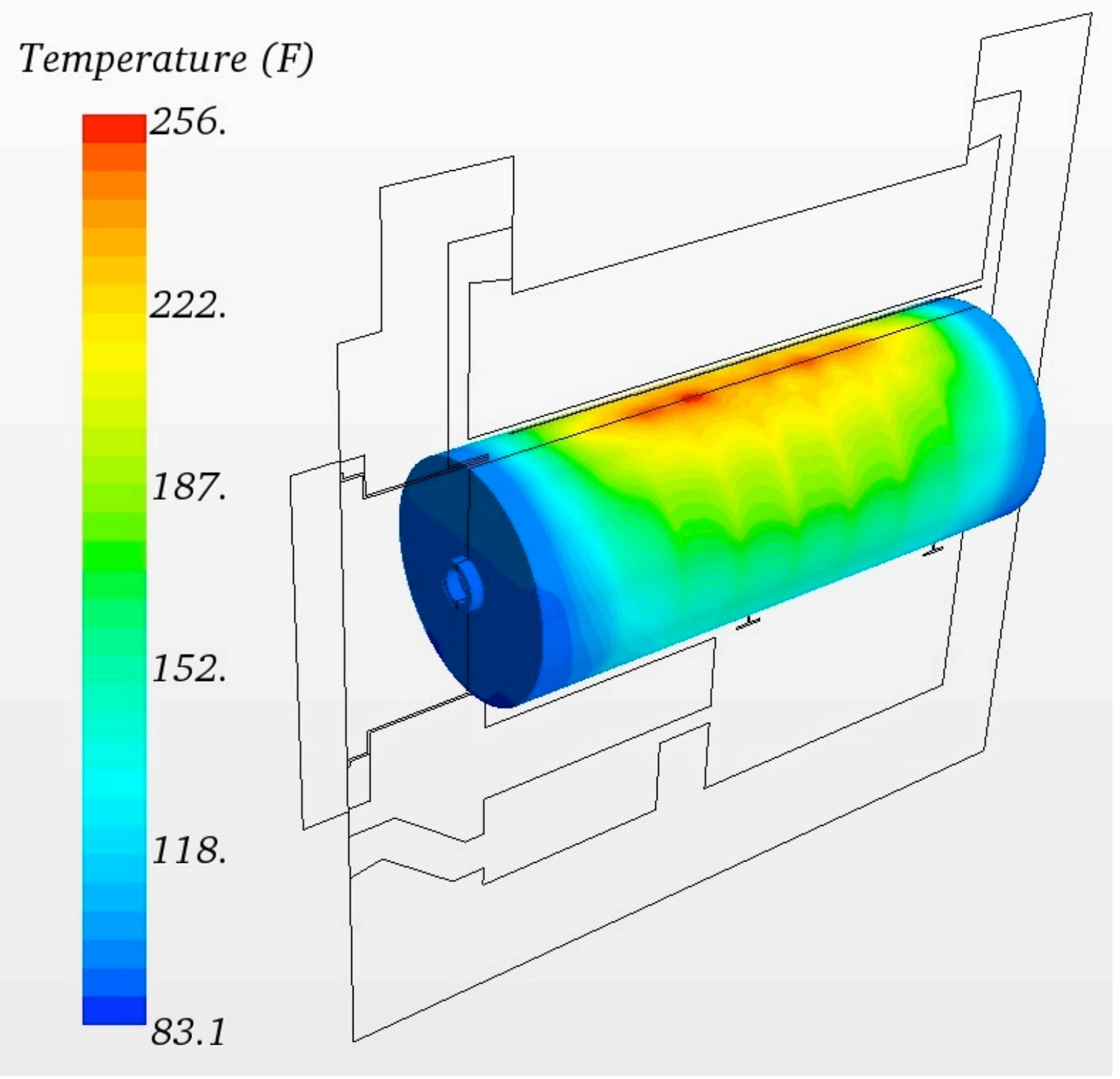

Figure 7.3. DSC Shell Surface Temperatures for Base Case (HSM-15) $-58^{\circ} \mathrm{F}\left(14^{\circ} \mathrm{C}\right)$ Ambient

In addition to the contour plots, detailed axial temperature distributions on the DSC shell, heat shields, and inner concrete wall surface of the module were obtained by extracting line probe values from the STAR-CCM+ results. Figure 7.4 illustrates the locations on the DSC shell, heat shields, and concrete where these results were obtained. Figure 7.5 shows the calculated temperatures extracted using the line probes for the DSC shell at the top, sides, and bottom surfaces. 


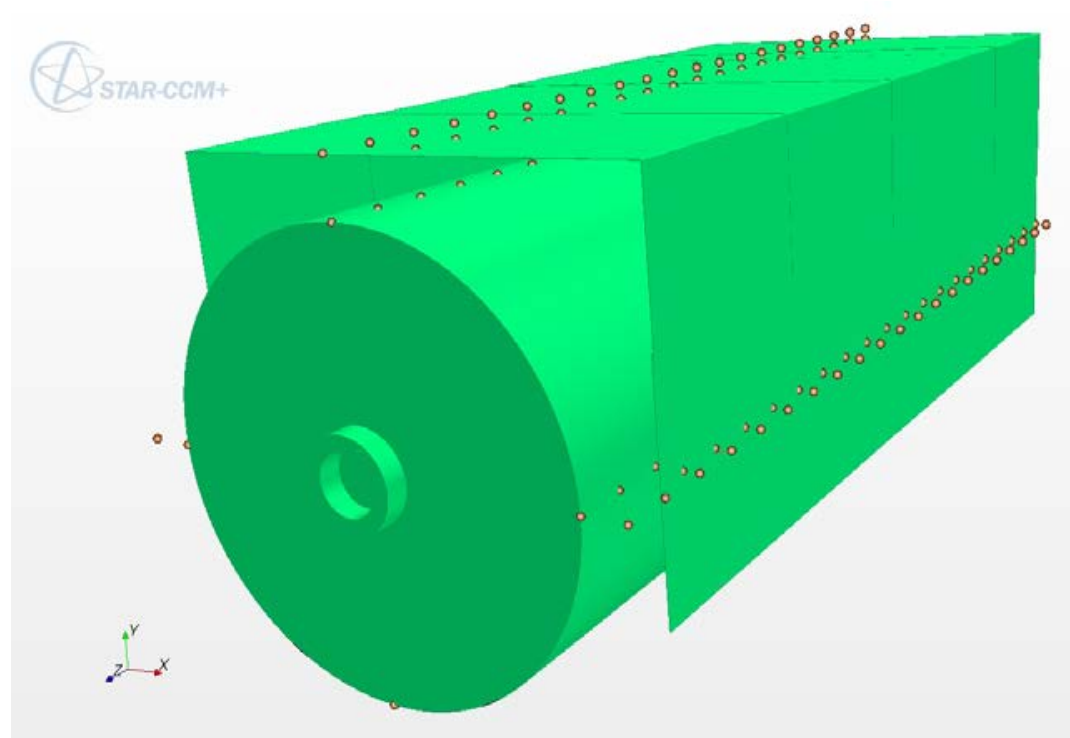

Figure 7.4. Line Probe Locations for Extracting Temperature Results from STAR-CCM+ Model (NOTE: Image Resolution of Probe Locations is not to Scale)

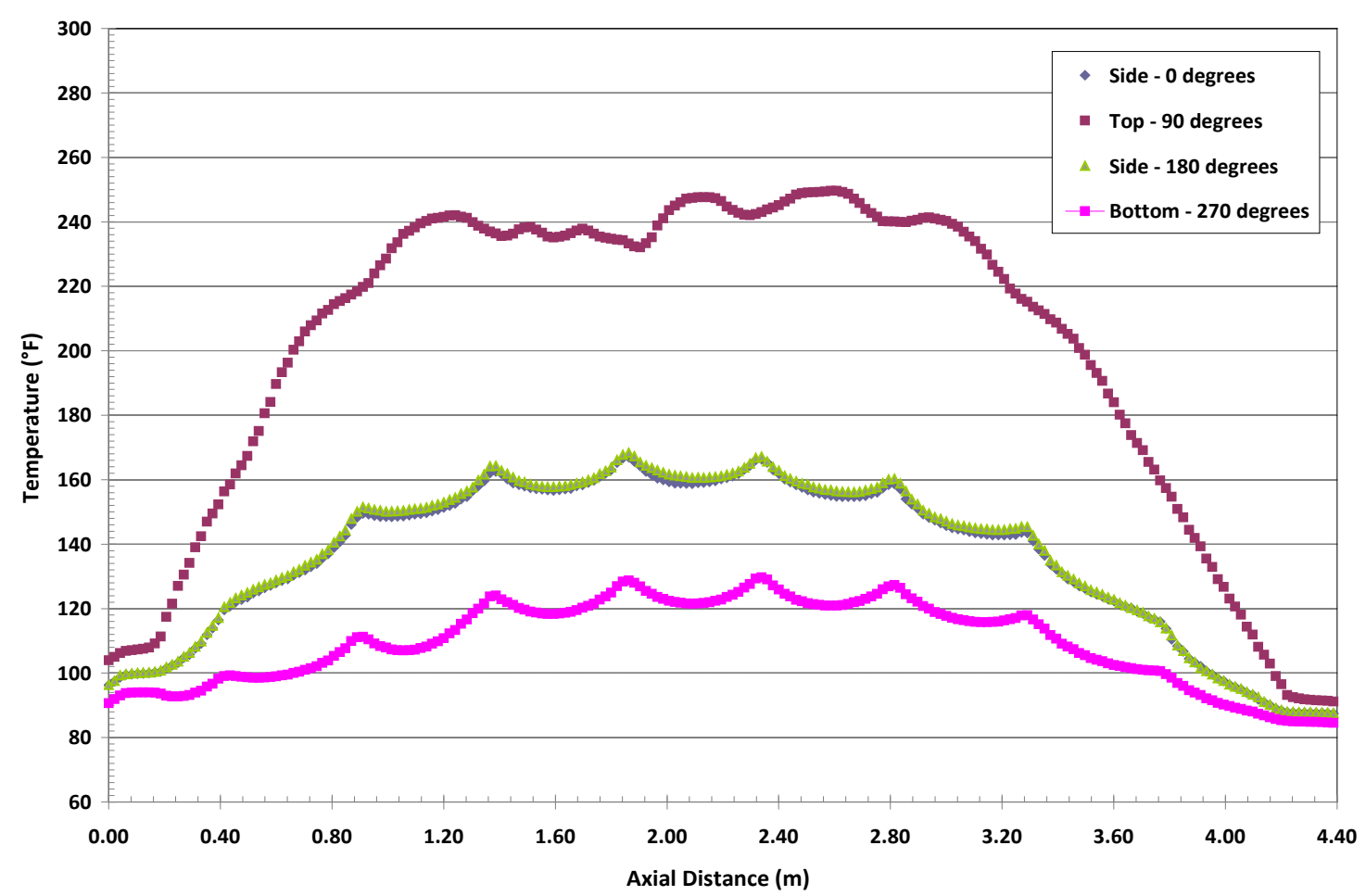

Figure 7.5. Calculated Temperatures on DSC Shell for Base Case (HSM-15) $-58^{\circ} \mathrm{F}\left(14^{\circ} \mathrm{C}\right)$ Ambient

The arbitrary convention chosen to describe the radial location of the line probes on the DSC shell designates the right side (viewed from the lid end) of the circular cross-section as the $0^{\circ}$ location, which results in the top being at $90^{\circ}$, the left side at $180^{\circ}$, and the bottom at $270^{\circ}$. The zero datum for the axial distance is the plane of the outer surface of the top of the DSC, which faces the back wall of the module 
cavity. These axial temperature profiles clearly show the effect of the support disks of the DSC internal structure, with peaks corresponding to the locations of the support disks. The direct conduction path allows heat to move more readily from the DSC internals to the shell along these structures. However, as noted in the discussion in Section 5.2 of contact resistance modeling for the spacer disks, more realistic modeling of the contact resistance may affect the circumferential distribution of these temperatures.

Some effect of the spacer disks is apparent in the axial temperature distribution at the top of the DSC shell, but this profile shows considerably more variation than the profiles on the sides and bottom. This is due to the complex recirculation flow between the top of the DSC shell and the top heat shield, as shown in Figures 7.1 and 7.2. The effect of this recirculation is also seen in the axial temperature profile at the center of the top heat shield, directly above the top of the DSC, as shown in Figure 7.6. For the concrete ceiling surface temperature, however, which is also shown in this plot, the effect of the local variations in the temperature profile of the DSC shell top and the heat shield has been damped out to a relatively smooth distribution.

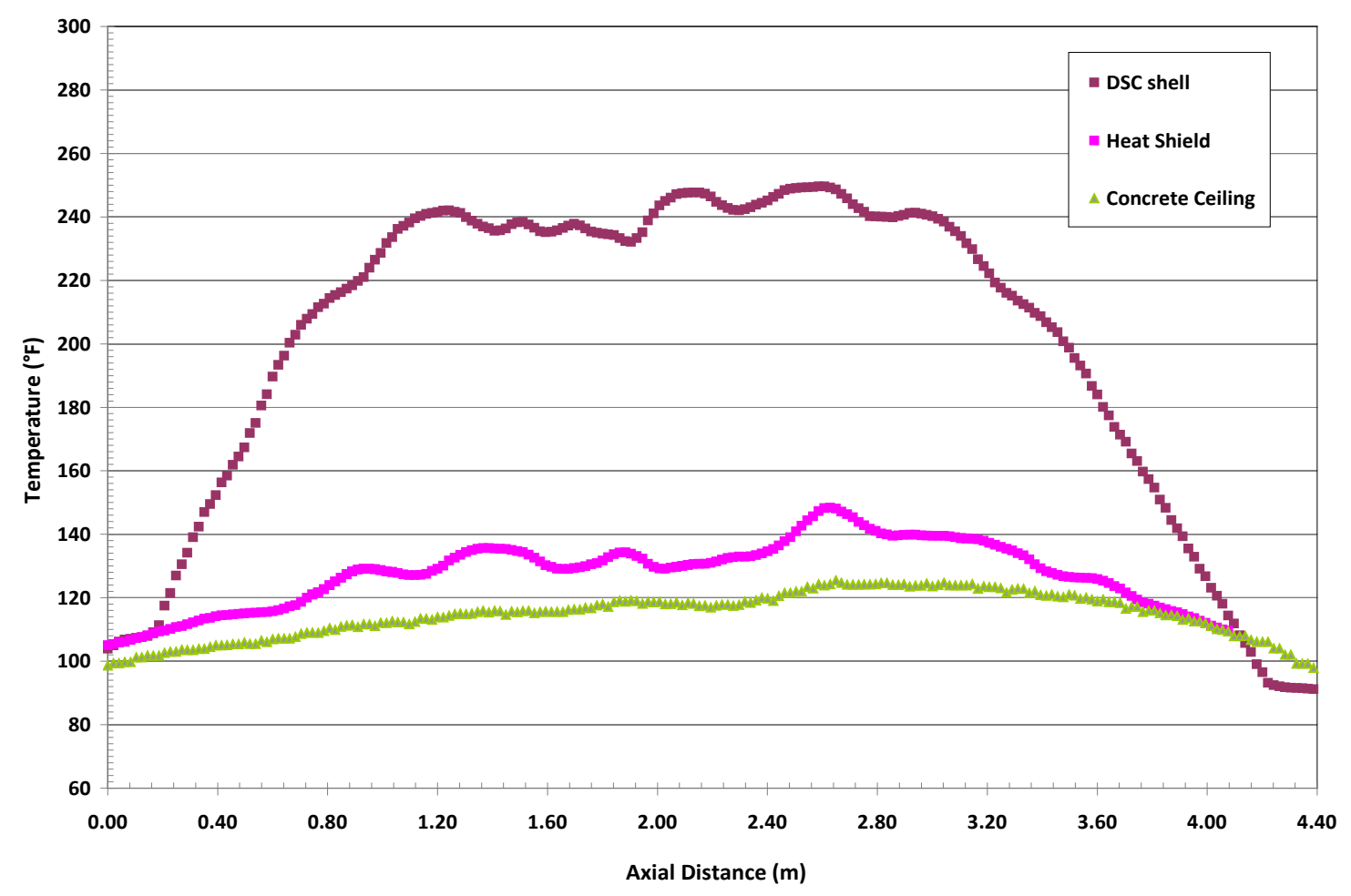

Figure 7.6. Calculated Temperatures: Top of DSC Shell, Centerline of Top Heat Shield, and Centerline of Concrete Ceiling, for Base Case (HSM-15) $-58^{\circ} \mathrm{F}\left(14^{\circ} \mathrm{C}\right)$ Ambient

The temperature profiles in Figure 7.7 show the temperature distributions for both sides of the DSC shell, and includes the profiles for the side heat shields and the concrete walls. There is a slight asymmetry in the corresponding profiles for the two sides, primarily due to the non-uniform decay heat loads in the individual fuel assemblies and the resulting asymmetric decay heat loading pattern within the DSC, as shown in Figure 5.3 above. On the scale of the graph in Figure 5.3, this asymmetry is discernible only in the DSC shell temperature profiles, since it consists of a temperature difference of less than 5 degrees $\mathrm{F}(\sim 3$ degrees $\mathrm{C})$. 


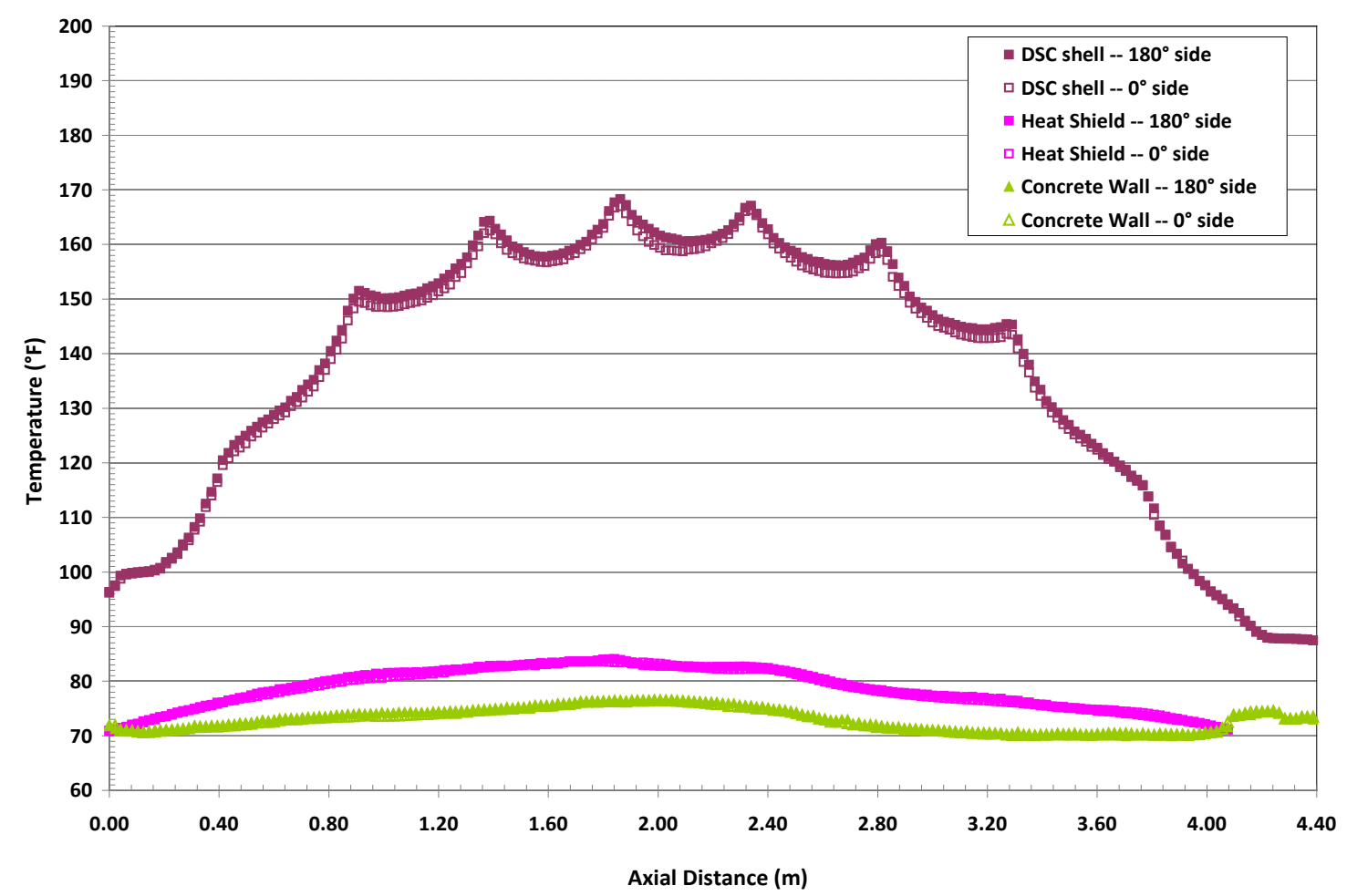

Figure 7.7. Calculated Temperatures: Sides of DSC Shell, Side Heat Shields, and Concrete Side Walls, for Base Case (HSM-15) $-58^{\circ} \mathrm{F}\left(14^{\circ} \mathrm{C}\right)$ Ambient

The effect of the slightly asymmetrical heat loading of the DSC has been damped almost completely away in the temperature distribution on the side heat shield, only inches from the DSC shell surface, and is not visible at all in the temperature profiles on the concrete side walls. For the heat shields, this behavior is due mainly to the relatively steady convection heat transfer around the sides of the DSC shell, where the air flow in the vertical direction is essentially unimpeded, and most of the heat removed from the DSC shell is carried upward.

\subsection{Effect of Seasonal Ambient Temperature Variation}

As discussed in Section 5.1, the effect of seasonal variation in ambient temperature conditions for the ISFSI was investigated by performing bounding calculations for ambient temperatures based on seasonal averages for the region. Figure 7.8 shows the radial temperature distribution at the center cross-section of the module for the base case, which assumes an annual average ambient temperature of $58^{\circ} \mathrm{F}\left(14^{\circ} \mathrm{C}\right)$. Figures 7.9 and 7.10 show the same cross-section for the summer (July) case at $77^{\circ} \mathrm{F}\left(25^{\circ} \mathrm{C}\right)$ and the winter (January) case at $35^{\circ} \mathrm{F}\left(2^{\circ} \mathrm{C}\right)$. Figure 7.11 shows a similar plot for the June average temperature, which represents the average conditions for the timeframe when measurements are to be taken in the module. These results are bounding estimates, as they assume steady-state conditions at the given ambient air temperatures, neglecting the thermal inertia of the system. 


\section{Temperature (F)}
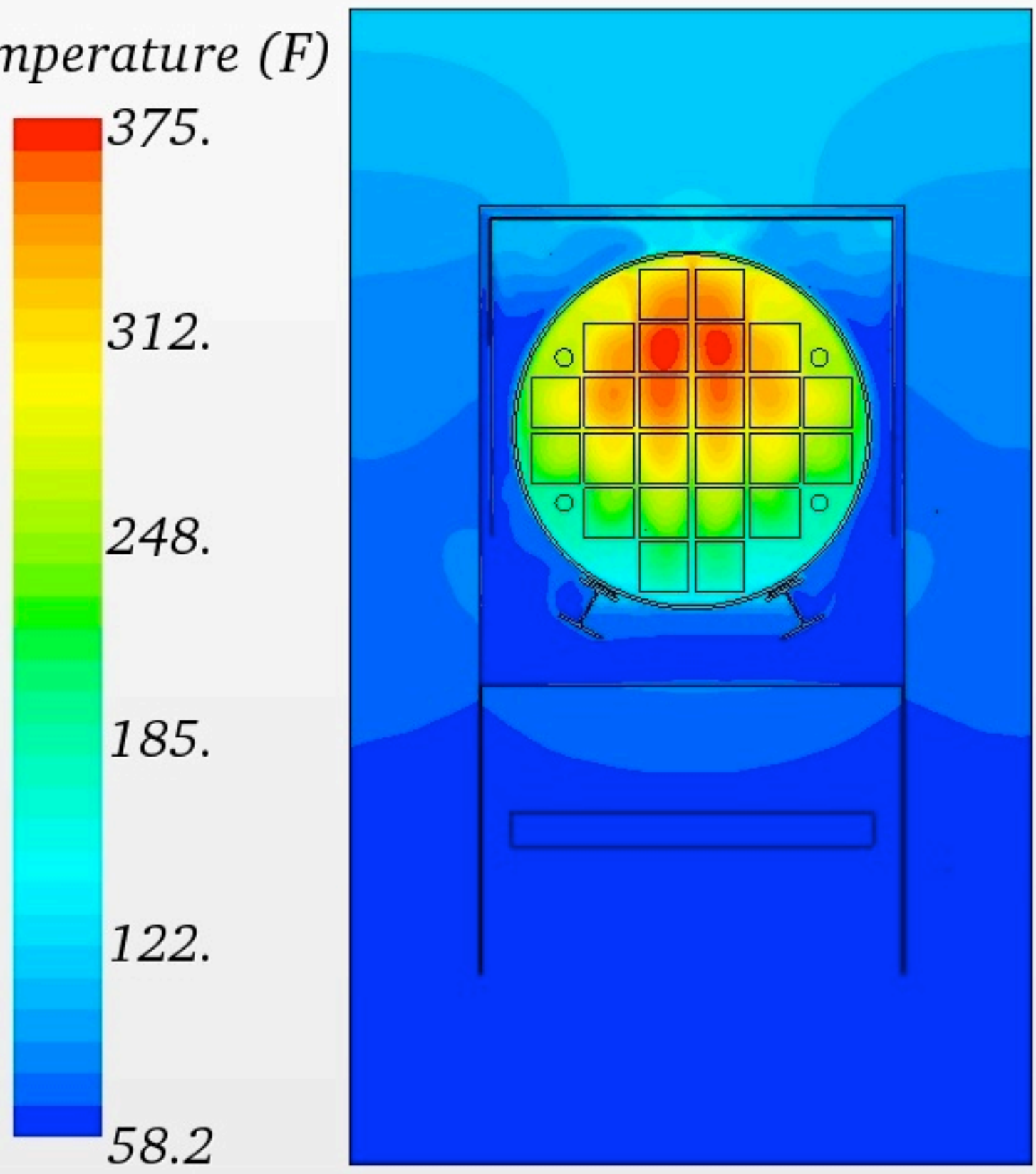

Figure 7.8. Temperature Distribution in Central Cross-section of HSM- 15 for Base Case $-58^{\circ} \mathrm{F}\left(14^{\circ} \mathrm{C}\right)$ Ambient 


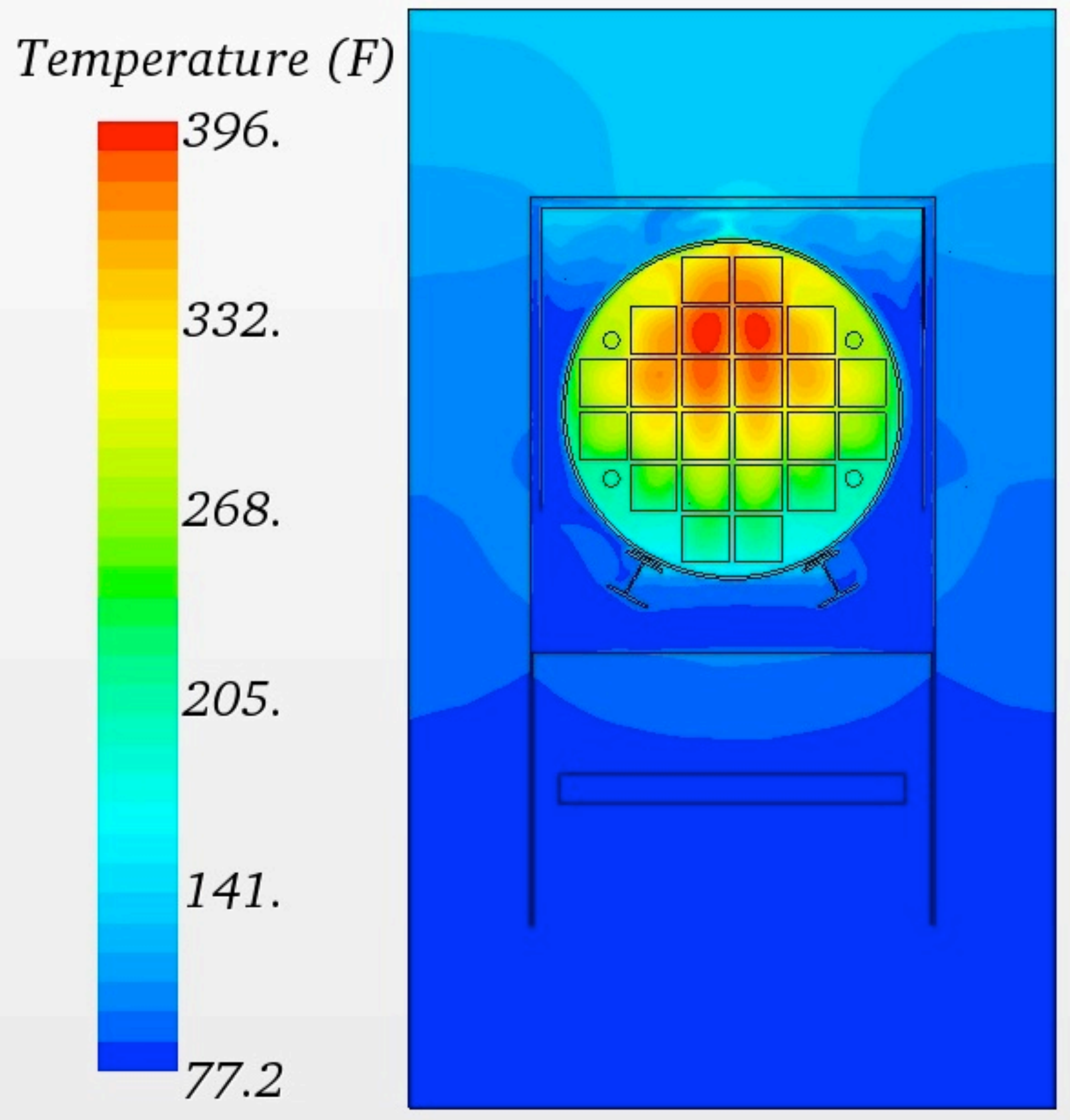

Figure 7.9. Temperature Distribution in Central Cross-section of HSM- 15 for Summer Case $-77^{\circ} \mathrm{F}$ $\left(25^{\circ} \mathrm{C}\right)$ Ambient 


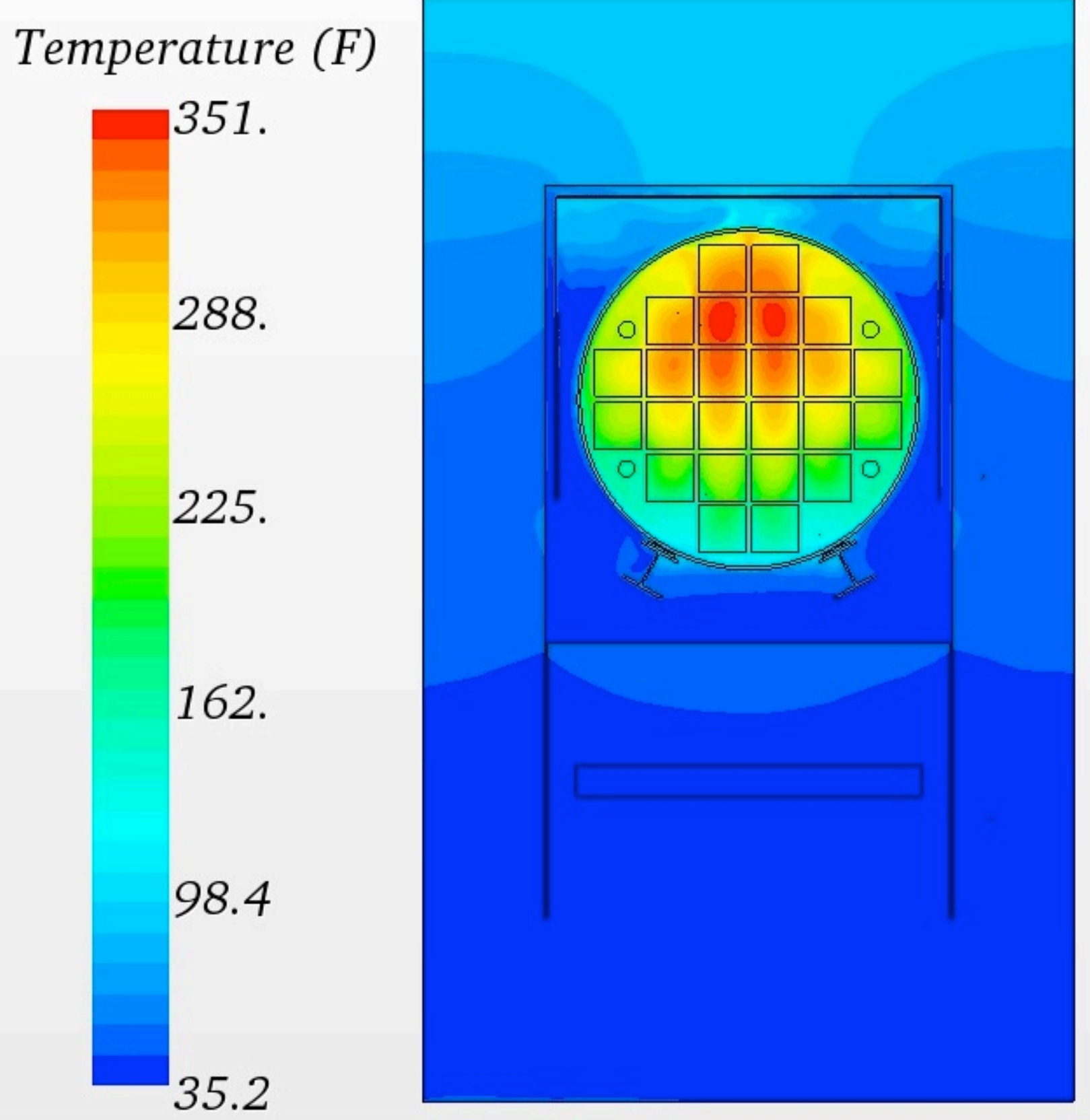

Figure 7.10. Temperature Distribution in Central Cross-section of HSM- 15 for Winter Case $-35^{\circ} \mathrm{F}$ $\left(2{ }^{\circ} \mathrm{C}\right)$ Ambient 


\section{Temperature (F)}

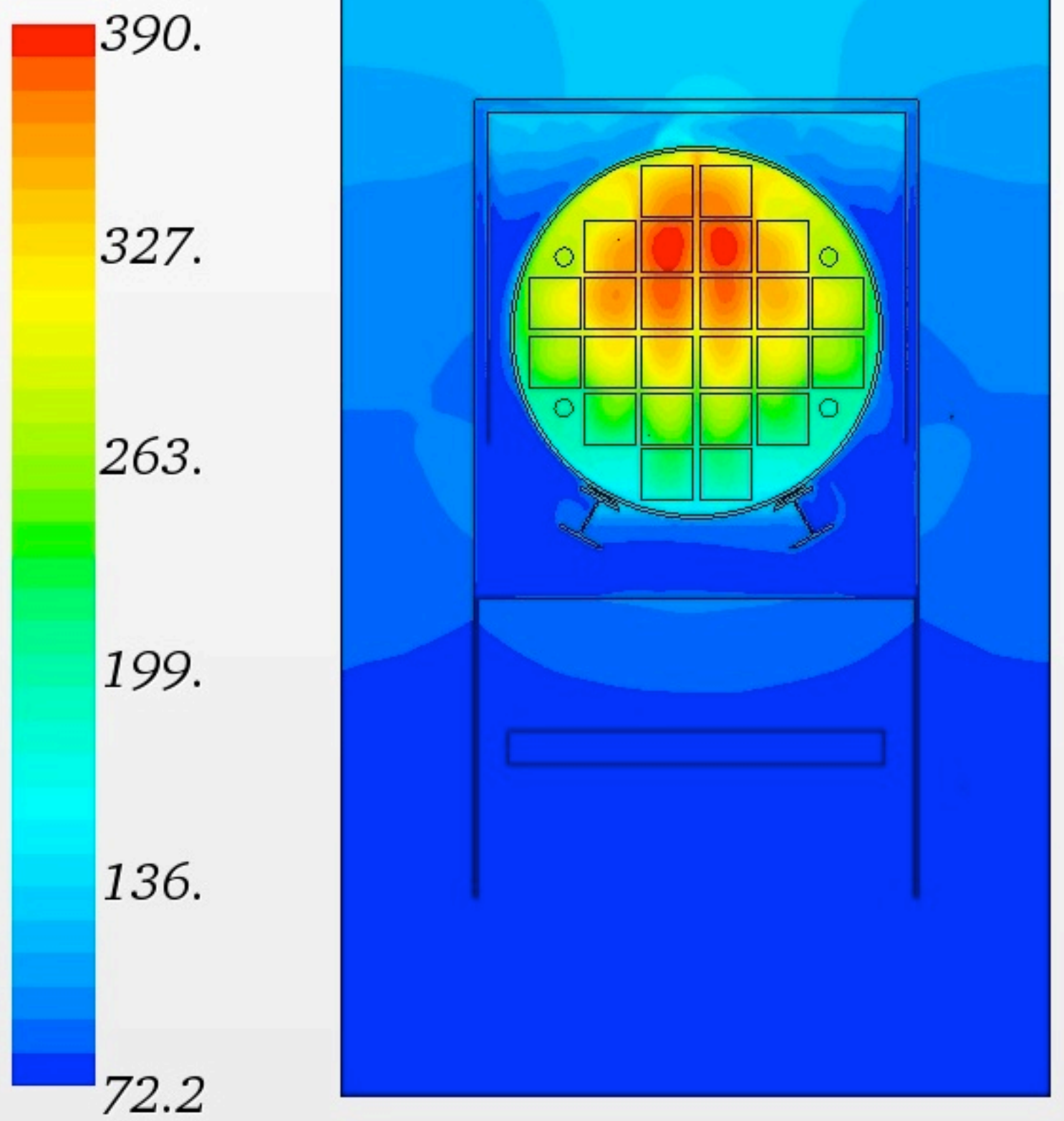

Figure 7.11. Temperature Distribution in Central Cross-section of HSM-15 for June Average Case $72^{\circ} \mathrm{F}\left(22^{\circ} \mathrm{C}\right)$ Ambient

Because these are steady-state calculations, the surface temperatures for the DSC shell, heat shields, and concrete walls directly follow the change in assumed ambient air temperature for these seasonal cases. Figure 7.12 shows this in detail with the calculated temperature distribution for the DSC shell top. 


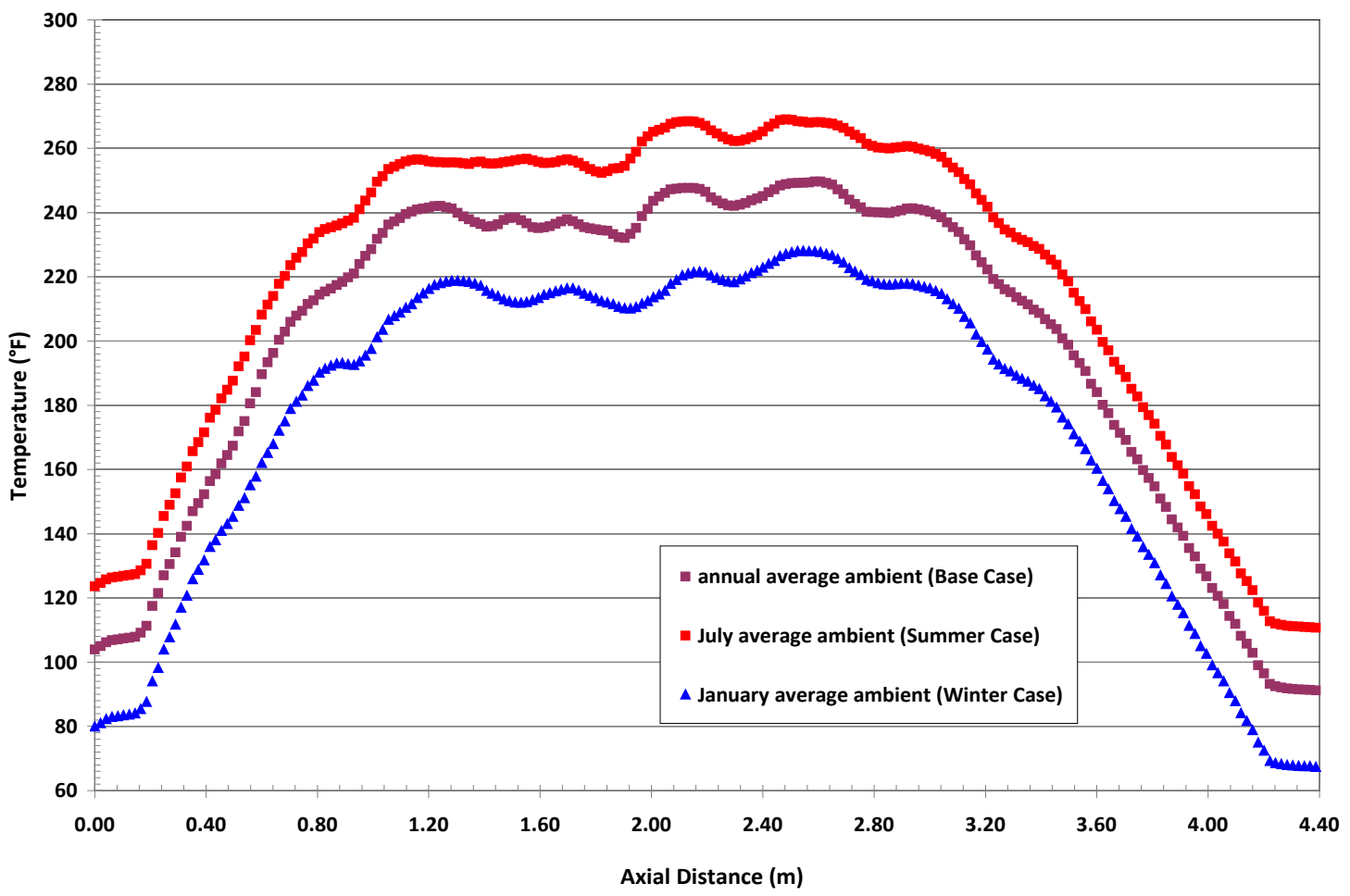

Figure 7.12. Calculated Temperatures: Top of DSC Shell, Bounding Seasonal Variation - Base Case at $58^{\circ} \mathrm{F}\left(14^{\circ} \mathrm{C}\right)$, Summer Case at $77^{\circ} \mathrm{F}\left(25^{\circ} \mathrm{C}\right)$, Winter Case at $35^{\circ} \mathrm{F}\left(2^{\circ} \mathrm{C}\right)$ 



\subsection{HSM-1 Model Geometry}

The HSM-15 model was developed initially with the expectation that temperature measurements would be obtained on the DSC surface for this module in the inspections planned for June 2012 at the Calvert Cliffs ISFSI. However, other program considerations resulted in the planned measurements being taken on the DSC in a different module, HSM-1. A single temperature measurement was taken on the DSC in HSM-15, but the majority of the measurements were taken on the DSC in HSM-1. To accommodate this change in program plans, a model representing the HSM-1 module at Calvert Cliffs was constructed using the HSM-15 model as a base.

The significant differences between the two modules are the DSC heat load and the location of the module within the storage array. The DSC in HSM-15 contains the highest decay heat load in the entire ISFSI. In contrast, the DSC in HSM-1 is the first canister loaded at Calvert Cliffs, with a relatively modest initial decay heat load, and consequently is the coldest canister in the system. The HSM-15 module is near the middle of the $2 \times 6$ array of modules (see Figure 1.1), and therefore can be adequately represented with adiabatic boundaries on both sides and the back wall. The HSM-1 module is located on the outer edge of the $2 \times 6$ array, and therefore has one side exposed to the ambient environment. In addition, the exposed wall of the HSM-1 module is much thicker than the interior walls between modules. The inner concrete walls are $2 \mathrm{ft}(0.61 \mathrm{~m})$ thick, and the end wall is $5.1 \mathrm{ft}(1.55 \mathrm{~m})$ thick. This is illustrated by the exterior view of the HSM-1 mesh in Figure 8.1, which shows the effect of the thicker outer wall on the location of the module doorway. External convection, solar insolation, and thermal radiation exchange with the environment were included in the model for the exposed side boundary of the concrete. 


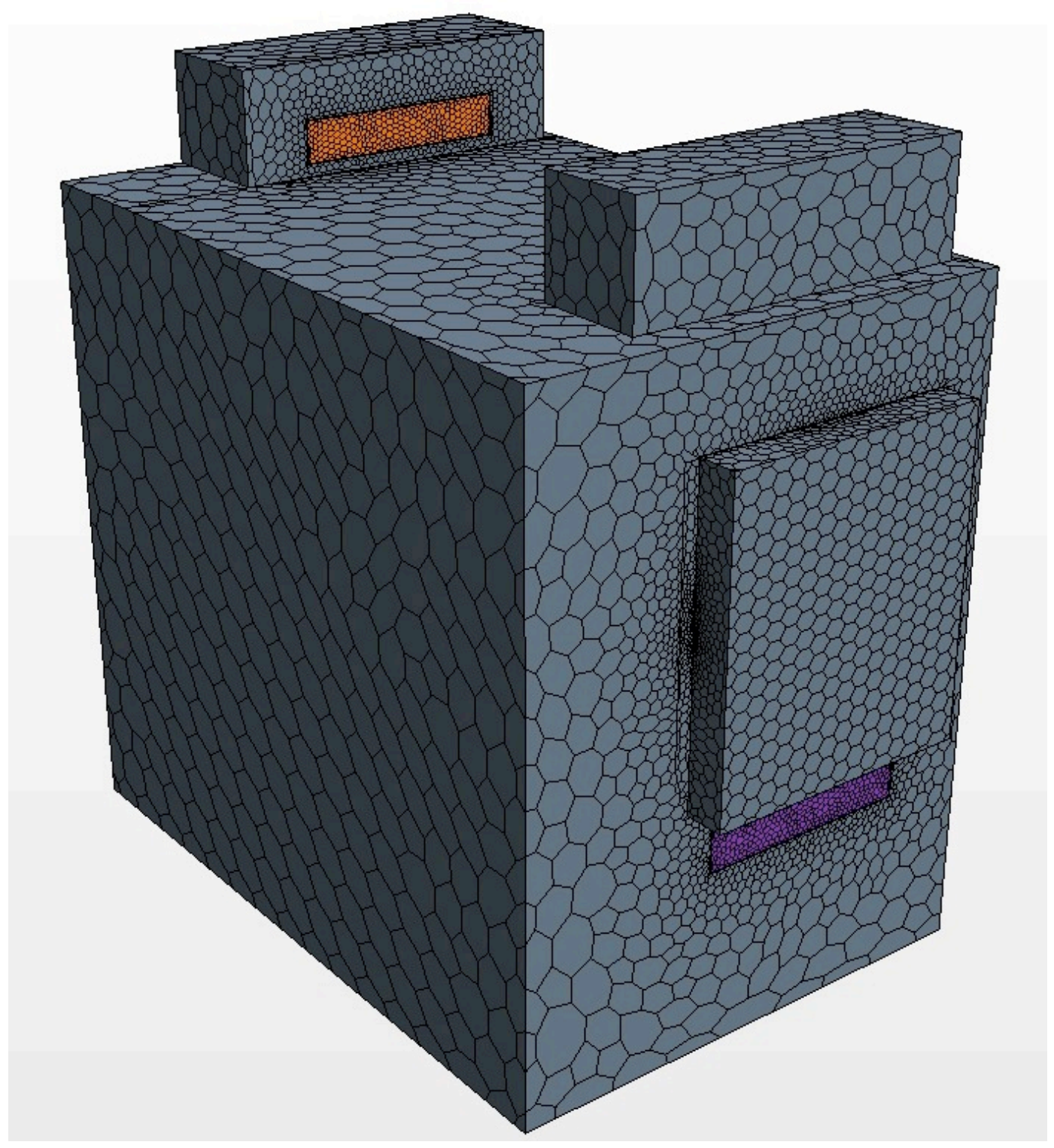

Figure 8.1. Volume Mesh of HSM-1 Assembly, Exterior View

In addition to the geometry changes for the HSM-1 module, the DSC within it has a lower decay heat load. The total decay heat load for the DSC is calculated at approximately $4.1 \mathrm{~kW}$ as of June 2012 , compared to the decay heat load of $7.6 \mathrm{~kW}$ as of this date for the DSC in HSM-15. Figure 8.2 shows the fuel assembly loading, and Table 8.1 lists the decay heat loads for each fuel assembly in the DSC within HSM-1. 


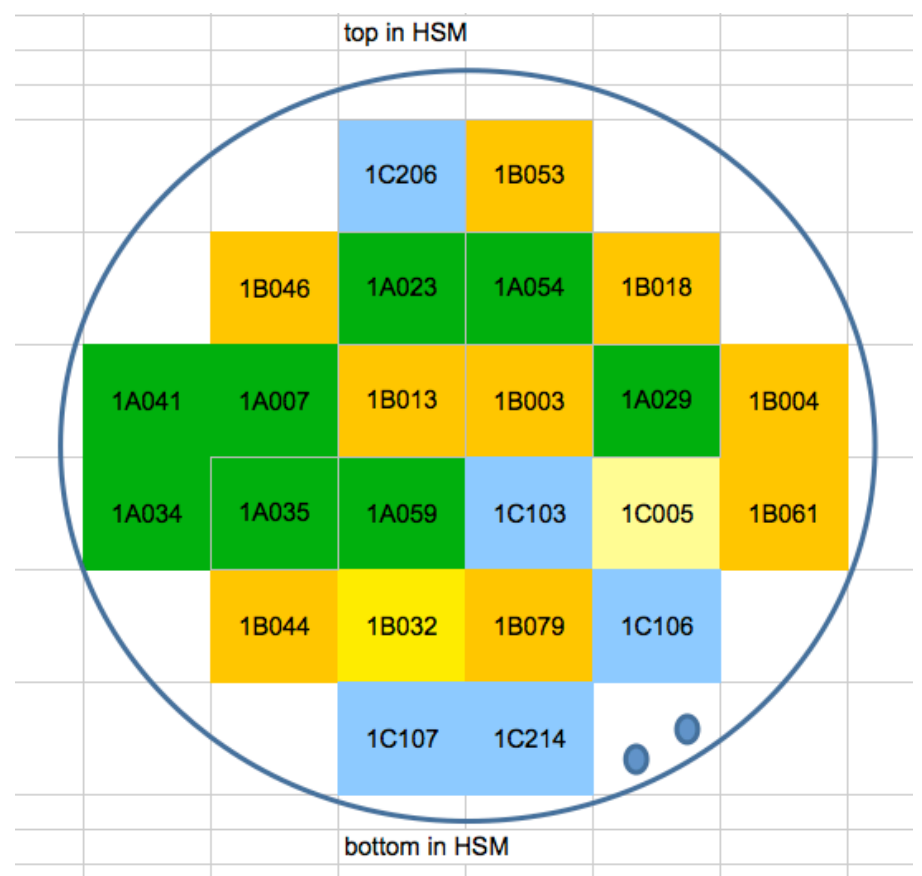

Figure 8.2. Fuel Assembly Loading and Identification Numbers for HSM-1

Table 8.1. Fuel Assembly Decay Heat Loads for DSC in HSM-1 as of June 2012

\begin{tabular}{|c|c|}
\hline $\begin{array}{c}\text { Fuel } \\
\text { Assembly } \\
\text { ID }\end{array}$ & $\begin{array}{c}\text { Heat } \\
\text { Load } \\
(\mathrm{kW})\end{array}$ \\
\hline $1 \mathrm{~B} 013$ & 0.1839 \\
\hline $1 \mathrm{~B} 003$ & 0.1989 \\
\hline $1 \mathrm{~A} 007$ & 0.1305 \\
\hline $1 \mathrm{~A} 059$ & 0.1374 \\
\hline $1 \mathrm{C} 103$ & 0.1899 \\
\hline $1 \mathrm{~A} 023$ & 0.1375 \\
\hline $1 \mathrm{~A} 054$ & 0.1393 \\
\hline $1 \mathrm{~B} 046$ & 0.1922 \\
\hline $1 \mathrm{C} 005$ & 0.1752 \\
\hline $1 \mathrm{~B} 079$ & 0.1874 \\
\hline $1 \mathrm{~B} 032$ & 0.1399 \\
\hline $1 \mathrm{~A} 029$ & 0.1382 \\
\hline $1 \mathrm{~A} 035$ & 0.133 \\
\hline $1 \mathrm{~B} 004$ & 0.1978 \\
\hline $1 \mathrm{~B} 018$ & 0.1977 \\
\hline $1 \mathrm{~A} 034$ & 0.1307 \\
\hline $1 \mathrm{C} 107$ & 0.1894 \\
\hline $1 \mathrm{~B} 053$ & 0.1847 \\
\hline $1 \mathrm{~B} 044$ & 0.1955 \\
\hline $1 \mathrm{C} 206$ & 0.2021 \\
\hline & \multicolumn{2}{|c|}{} \\
\hline
\end{tabular}




\begin{tabular}{|c|c|}
\hline $\begin{array}{c}\text { Fuel } \\
\text { Assembly } \\
\text { ID }\end{array}$ & $\begin{array}{c}\text { Heat } \\
\text { Load } \\
(\mathrm{kW})\end{array}$ \\
\hline $1 \mathrm{~A} 041$ & 0.1374 \\
\hline $1 \mathrm{C} 106$ & 0.1983 \\
\hline $1 \mathrm{C} 214$ & 0.2017 \\
\hline $1 \mathrm{~B} 061$ & 0.198 \\
\hline
\end{tabular}

The lower total decay head load, extended concrete side wall, and revised boundary conditions applied along the exposed side (i.e. solar, external convection, and radiation) are the only differences between the models developed for the HSM-1 and HSM-15 modules.

\subsection{HSM-1 Model Results}

For the pre-test predictions of temperatures and temperature distributions on and within HSM-1, the ambient air temperature was assumed to be at the 'summer case' value of $77^{\circ} \mathrm{F}\left(25^{\circ} \mathrm{C}\right)$ determined from historical weather data, as described in Section 5.1 above. Table 8.2 lists the maximum and minimum temperatures for the main components of the model.

Table 8.2. Component Maximum and Minimum Temperatures: Summer Case (HSM-1)

\begin{tabular}{|c|c|c|}
\hline \multirow{2}{*}{} & \multicolumn{2}{|c|}{$\begin{array}{c}\text { Summer Case } \\
\text { Temperatures } \\
\left(\mathrm{amb} .77^{\circ} \mathrm{F}\left(25^{\circ} \mathrm{C}\right)\right)\end{array}$} \\
\cline { 2 - 3 } Components & $\begin{array}{c}\text { Max } \\
\left({ }^{\circ} \mathrm{F}\left({ }^{\circ} \mathrm{C}\right)\right)\end{array}$ & $\begin{array}{c}\text { Min } \\
\left({ }^{\circ} \mathrm{F}\left({ }^{\circ} \mathrm{C}\right)\right)\end{array}$ \\
\hline Concrete & $128(53)$ & $77(25)$ \\
\hline DSC shell & $197(92)$ & $95(35)$ \\
\hline Fuel & $265(129)$ & $110(43)$ \\
\hline Heat Shield & $134(57)$ & $83(28)$ \\
\hline
\end{tabular}

The results obtained for the HSM-1 model are similar to those obtained for the HSM-15 model, but at lower temperatures, reflecting the lower decay heat load for the DSC in HSM-1. Figure 8.3 shows the axial temperature distributions predicted for top surface of the DSC shell, top heat shield and concrete ceiling. Figure 8.4 shows the axial temperature distributions for the left and right sides of the DSC shell, and the corresponding heat shield and concrete wall temperatures. 


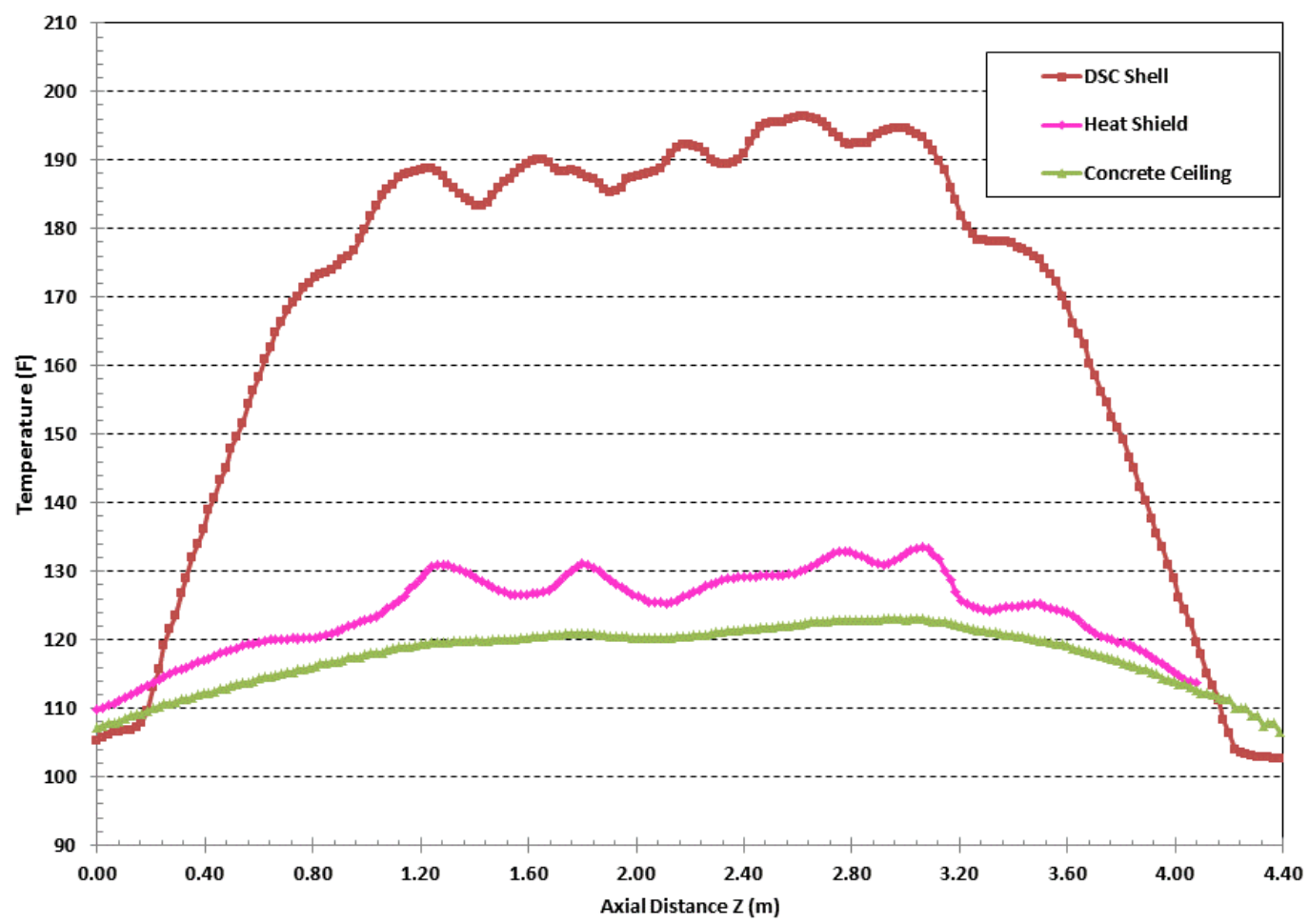

Figure 8.3. Calculated Temperatures: Top of DSC Shell, Centerline of Top Heat Shield, and Centerline of Concrete Ceiling, for Summer Case (HSM-1) - Ambient Air $77^{\circ} \mathrm{F}\left(25^{\circ} \mathrm{C}\right)$ 


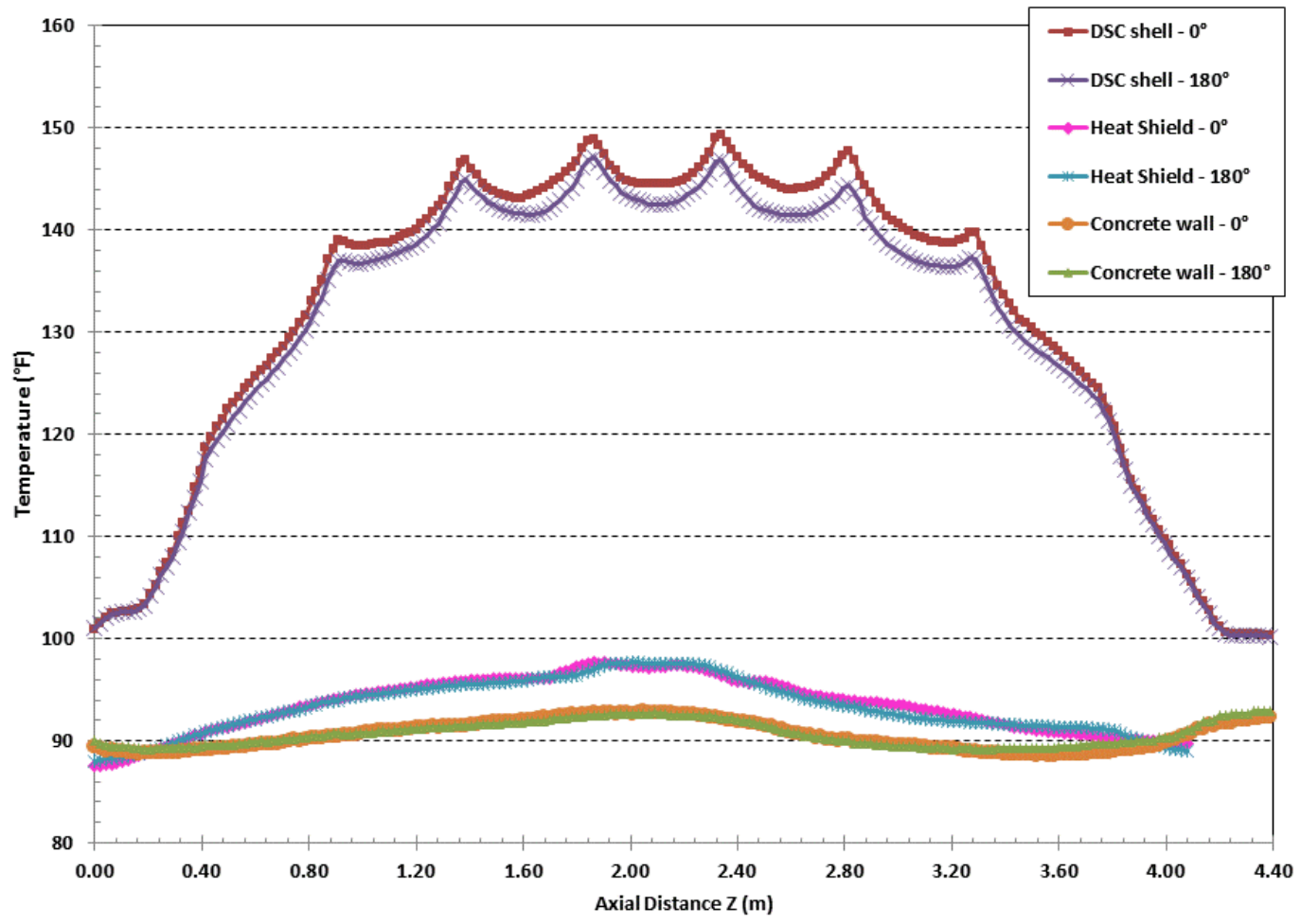

Figure 8.4. Calculated Temperatures: Sides of DSC Shell, Side Heat Shields, and Concrete Side Walls, for Summer Case (HSM-1) - Ambient Air $77^{\circ} \mathrm{F}\left(25^{\circ} \mathrm{C}\right)$ 


\subsection{Model Results Compared to Measured Temperatures}

Over a 2-day period (June 27-28, 2012), visual inspections, surface sampling, and temperature measurements were performed on HSM-1 and HSM-15 at the Calvert Cliffs Nuclear Power Station ISFSI. On June $27^{\text {th }}$, video inspections were performed by inserting a General Electric pan-tilt-zoom (PTZ) camera through the rear exhaust vent of each module. On the following day, June $28^{\text {th }}$, the front door of each module was opened in turn, to obtain surface samples and perform limited temperature measurements. For the purposes of this evaluation, only the temperature measurements are relevant; discussion and evaluation of the material samples must be sought elsewhere.

Due to physical constraints on the accessible regions of the DSC and considerations of worker safety, temperature measurements were obtained only on the exposed face of the canister base, and a short distance along the canister side. HSM-15 was open for only about 20 minutes, and a single temperature measurement was obtained on the exposed base of the DSC. HSM-1 was open for a much longer period, approximately 160 minutes, and a total of 16 temperature measurements were obtained on the base and sides of the canister. Temperature measurements were taken by touching a hand-held thermocouple probe $^{1}$ to the surface of the canister and recording the reading on a data sheet. Figure 9.1 illustrates the specific locations sampled in this manner on the accessible exposed face of the canister (which is the canister base, due to the prescribed loading configuration).

\footnotetext{
${ }^{1}$ The temperatures were measured with an Omega "All-in-One" hand-held thermometer, Model 450-AET with Type E Chromega ${ }^{\circledR}$-constantan thermocouple, or a Model 450-APT platinum RTD thermocouple. Either option (as specified in the test procedures) has an uncertainty of less than $\pm 1^{\circ} \mathrm{F}\left( \pm 0.5^{\circ} \mathrm{C}\right)$, in the temperature range encountered in this testing.
} 


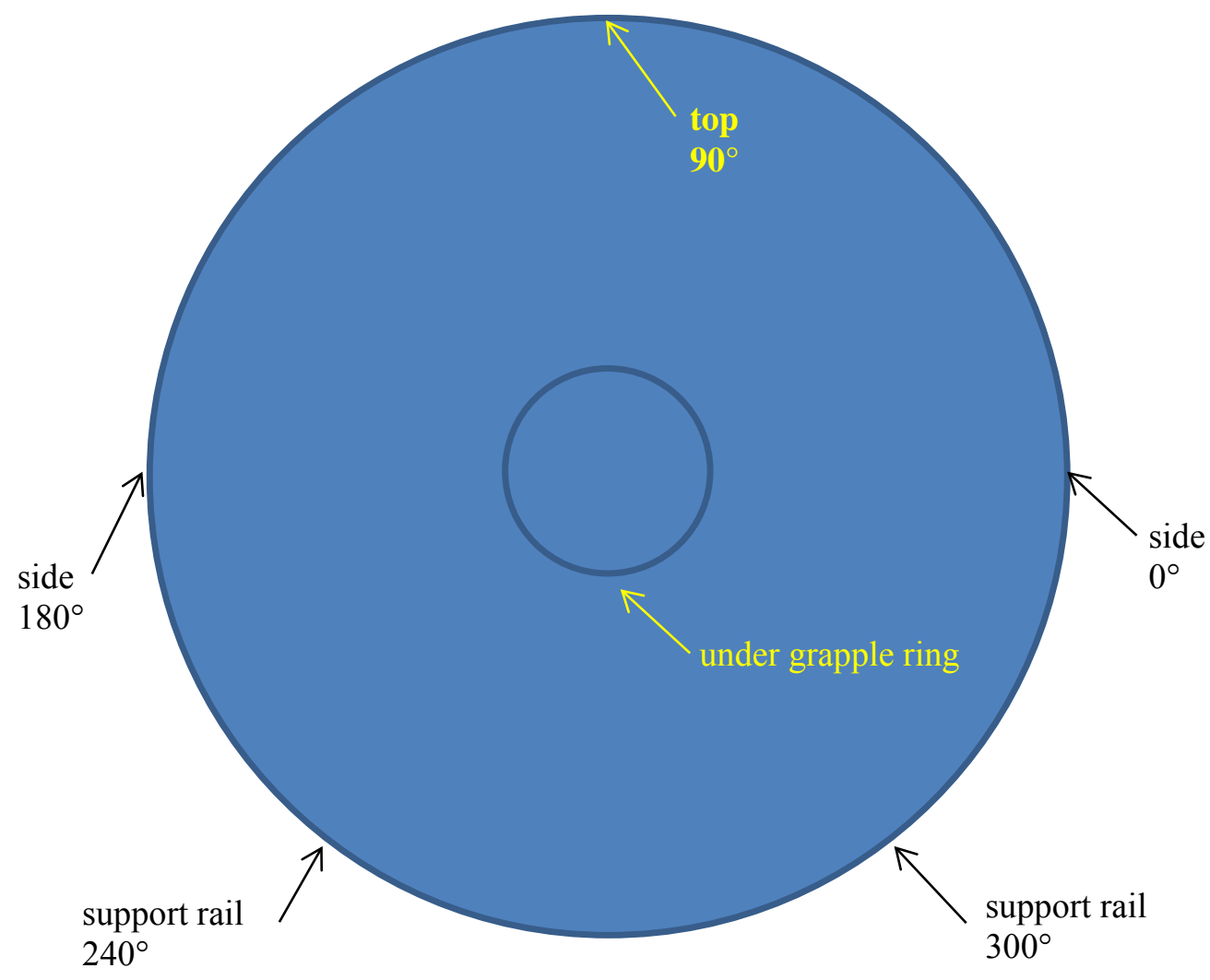

Figure 9.1. Location of Temperature Measurements on DSC Base

The length of the TC probe allowed a maximum reach of only about 40 inches along the side of the canister, approximately $1 / 4^{\text {th }}$ of the total axial length of the DSC. Temperatures measurements were obtained at three axial locations;

- 40.125 in. $(1.02 \mathrm{~m})$ from the exposed surface of the DSC base, which was the farthest the probe could reach

- 20.06 in. $(0.51 \mathrm{~m})$, with the probe inserted half its length

- 0.0 in. $(0.0 \mathrm{~m})$, essentially flush with the bottom edge of the DSC shell.

Measurements were obtained at the top, sides, and support rails locations indicated in Figure 9.1. Due to a slight asymmetry of the DSC within the bore of the module cavity, the probe could not be inserted at the lower edge of the DSC, and no measurements were obtained on the canister for this location.

For HSM-15, the single surface temperature measurement was taken just below the grapple ring of the DSC. The temperature was also measured at this location on the DSC for HSM-1, along with the additional temperature points axially along the side of the DSC. In the Star-CCM+ models of both the HSM-15 and HSM-1, a temperature probe was set up to capture the predicted temperature at the "under grapple ring" location. Two additional line probes were added at the rail/DSC interfaces of the model, in addition to the line probes previously set up to capture the calculated temperatures axially along the top, 
sides, and bottom of the canister. Table 9.1 compares the measured ${ }^{2}$ temperatures with those predicted for the summer case (ambient temperature of $77^{\circ} \mathrm{F}\left(25^{\circ} \mathrm{C}\right)$ ) with the HSM-1 and HSM- 15 models. The tabulated comparison is shown graphically in Figure 9.2, with a plot of the model results and the measured TC data over the first $1.1 \mathrm{~m}$ of the axial length of the DSC, relative to the base.

Table 9.1. Comparison of Measured and Predicted Temperatures (Pre-test Models)

\begin{tabular}{|c|c|c|c|c|}
\hline & \multicolumn{4}{|c|}{ Temperature $\left({ }^{\circ} \mathrm{F}\left({ }^{\circ} \mathrm{C}\right)\right)$} \\
\cline { 2 - 5 } & TC measurement & $\begin{array}{c}\text { TC } \\
\text { measurement } \\
\text { HSM-15 }\end{array}$ & $\begin{array}{c}\text { CFD Model } \\
\text { HSM-1 }\end{array}$ & $\begin{array}{c}\text { CFD Model } \\
\text { HSM-15 }\end{array}$ \\
\cline { 2 - 5 } Temperature Location & $112(44)$ & $124(51)$ & $100(38)$ & $110(43)$ \\
\hline Under Grapple Ring & $108(42)$ & n/a & $100(38)$ & $110(43)$ \\
\hline Side $\left(0^{\circ}\right)-0.0$ in. $(0.0 \mathrm{~m})$ & $109(43)$ & n/a & $116(47)$ & $133(56)$ \\
\hline Side $\left(0^{\circ}\right)-20$ in. $(0.51 \mathrm{~m})$ & $108(42)$ & n/a & $136(58)$ & $164(73)$ \\
\hline Side $\left(0^{\circ}\right)-40$ in. $(1.02 \mathrm{~m})$ & $115(46)$ & n/a & $103(39)$ & $114(46)$ \\
\hline Top $\left(90^{\circ}\right)-0.0$ in. $(0.0 \mathrm{~m})$ & $117(47)$ & $\mathrm{n} / \mathrm{a}$ & $142(61)$ & $180(82)$ \\
\hline Top $\left(90^{\circ}\right)-20$ in. $(0.51 \mathrm{~m})$ & $119(48)$ & $\mathrm{n} / \mathrm{a}$ & $178(81)$ & $242(117)$ \\
\hline Top $\left(90^{\circ}\right)-40$ in. $(1.02 \mathrm{~m})$ & $104(40)$ & $\mathrm{n} / \mathrm{a}$ & $100(38)$ & $110(43)$ \\
\hline Side $\left(180^{\circ}\right)-0.0$ in. $(0.0 \mathrm{~m})$ & $105(41)$ & $\mathrm{n} / \mathrm{a}$ & $115(46)$ & $135(57)$ \\
\hline Side $\left(180^{\circ}\right)-20$ in. $(0.51 \mathrm{~m})$ & $108(42)$ & $\mathrm{n} / \mathrm{a}$ & $134(57)$ & $167(75)$ \\
\hline Side $\left(180^{\circ}\right)-40$ in. $(1.02 \mathrm{~m})$ & $106(41)$ & $\mathrm{n} / \mathrm{a}$ & $97(36)$ & $104(40)$ \\
\hline Rail $\left(240^{\circ}\right)-0.0$ in. $(0.0 \mathrm{~m})$ & $107(42)$ & $\mathrm{n} / \mathrm{a}$ & $101(38)$ & $112(44)$ \\
\hline Rail $\left(240^{\circ}\right)-20$ in. $(0.51 \mathrm{~m})$ & $108(42)$ & $\mathrm{n} / \mathrm{a}$ & $109(43)$ & $123(51)$ \\
\hline Rail $\left(240^{\circ}\right)-40$ in. $(1.02 \mathrm{~m})$ & $105(41)$ & $\mathrm{n} / \mathrm{a}$ & $97(36)$ & $104(40)$ \\
\hline Rail $\left(300^{\circ}\right)-0.0$ in. $(0.0 \mathrm{~m})$ & $106(41)$ & $\mathrm{n} / \mathrm{a}$ & $101(38)$ & $111(44)$ \\
\hline Rail $\left(300^{\circ}\right)-20$ in. $(0.51 \mathrm{~m})$ & $106(41)$ & $\mathrm{n} / \mathrm{a}$ & $109(43)$ & $122(50)$ \\
\hline Rail $\left(300^{\circ}\right)-40$ in. $(1.02 \mathrm{~m})$ & & &
\end{tabular}

\footnotetext{
${ }^{2}$ The measured data was transmitted via e-mail on July 5, 2012, from John Massari of Calvert Cliffs, and consisted of a digital image of a portion of one page of a Data Collection Sheet. This image is reproduced in Appendix D of this document. There are currently no plans to publish the data elsewhere, so by default, this report constitutes primary publication of these temperature measurements.
} 


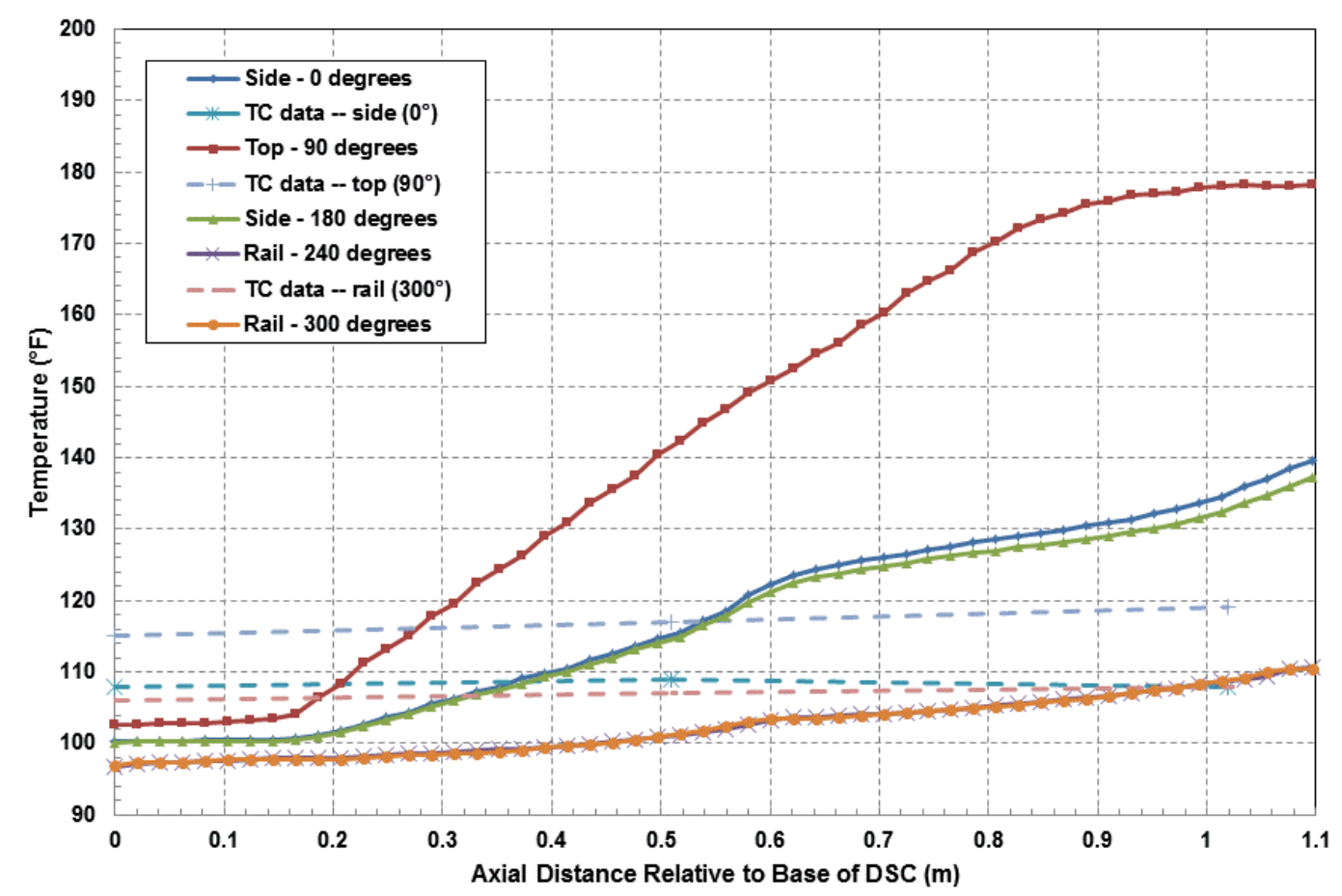

Figure 9.2. Comparison of Measured to Predicted Axial Temperatures on DSC in HSM-1

The pre-test results obtained with the models under-predict the measured temperatures at the "Under Grapple Ring" location by about 12-14 degrees F (7-8 degrees C), for the DSC exposed face in both modules. The predicted temperatures are also slightly lower for the DSC side at 0.0 inches (i.e., at the base of the DSC) for the DSC in the HSM-1 module. For the axial locations at 20 inches $(0.51 \mathrm{~m})$ and 40 inches $(1.02 \mathrm{~m})$, however, the predicted temperatures are generally higher, and the model shows a much steeper axial temperature gradient along the DSC surface. The measured data for the DSC in HSM-1 shows a gradient of only 4 degree-F/m $(\sim 2$ degree-C/m) along the top surface of the DSC, while the CFD model predicts an average gradient of approximately 77 degrees-F/m (43 degree- $\mathrm{C} / \mathrm{m})$ along the top surface.

The temperature gradients along the side of the DSC in HSM-1 in the measured data are extraordinarily flat for this system, and are physically unrealistic for the known axial heating profile and total decay heat load in this DSC. Given the difficulties in accurate insertion of the probe through the very narrow gap between the DSC and the storage module wall, the side temperatures are too uncertain to be useful for comparison with model predictions. Therefore, in the post-test evaluations of the model, comparisons are made only with the temperature measurements from the 'under grapple ring' location and the 0.0 -inches location on the exposed face of the DSC.

In the post-test evaluation of the model results, information that had been previously unavailable on significant features of the DSC and HSM modules was provided. Modifications were made to the CFD models to more accurately represent the actual configuration of the HSM and the conditions at the time the measurements were taken. These modifications and the effect on predicted temperatures are discussed in the following section. 


\subsection{Modifications to the Models}

In comparing the assumptions used for the pre-test calculations to actual test conditions, three significant items were identified that could be expected to have a noticeable influence on the model predictions. These included

- new information on the configuration of the protective screening on the inlet and outlet vents of the storage module, which would increase the inlet and outlet pressure drops, and would have some effect on the total air flow rate through the system

- the actual ambient temperature at the time of testing, which was significantly warmer than the seasonal average assumed for the pre-test predictions

- new information on the axial positioning of the fuel within the DSC, which affected the assumed distribution of the decay heat load within the model

In addition, sensitivity studies were performed to assess the effect of non-uniform contact between the cylindrical spacer disks and DSC. An additional bounding case assuming no convection in the helium fill gas was evaluated, to quantify the effect of internal convection in the helium backfill gas within the DSC on surface temperatures and temperature distribution. These evaluations are presented in Appendix C.

The HSM models were modified to account for these differences from the original pre-test modeling assumptions. Section 10.1 discusses the approach used to model the effect of the vent screens. Section 10.2 discusses the local weather conditions at the time of testing, and the determination of a more realistic estimate of ambient air temperature. Results obtained with the modified models are presented in Section 10.3, with a discussion of the significance of the post-test modifications.

\subsection{Modeling of Vent Screens}

In addition to the relatively open-mesh "bird screens" typically included on storage module vents, the modules at the Calvert Cliffs ISFSI include an inner screen of fine-mesh stainless steel wire cloth. The presence of these screens introduces an additional resistance to air flow through the module that was not accounted for in the pre-test predictions obtained with the HSM-1 and HSM-15 models.

The basic "bird screen" on the vents of the modules is a welded steel bar grating with relatively large openings, each approximately 1 inch high and 4 inches wide. These openings are large enough to have essentially negligible effect on the inlet or exit flow rate through the vents. The inner screen on these vents, however, is a 16x16 mesh stainless steel wire cloth that reduces the open area for flow by about $27 \%$. This reduction in flow area at the inlet and outlet vents is sufficient to have a noticeable effect on the overall pressure drop of the system, and therefore on the total air flow rate.

The models of the two modules were modified to include the pressure drop across the screen using a straight-forward momentum loss relationship for porous screens (Perry and Green, 1997). The formulation of the model is given in the following equations. 


$$
\begin{gathered}
\Delta p=K \frac{\rho V^{2}}{2} \\
K=\left(\frac{1}{C^{2}}\right)\left(\frac{1-\varepsilon^{2}}{\varepsilon^{2}}\right)
\end{gathered}
$$

Where

$\Delta p=$ pressure drop

$\rho=$ fluid density

$\mathrm{V}=$ superficial velocity based upon the gross area of the screen

$\mathrm{K}=$ velocity head loss

$\mathrm{C}=$ discharge coefficient

$\varepsilon=$ screen porosity

The discharge coefficient $\mathrm{C}$ in Equation (10.2) is a function of the screen's Reynolds number $(\mathrm{Re})$, defined as.

$$
\operatorname{Re}=\frac{D_{s} V \rho}{\varepsilon \mu}
$$

Where

$D_{S}=$ aperture length

$\boldsymbol{\mu}=$ fluid viscosity

For the wire screen of the module, the aperture length is 0.054 inches. The discharge coefficient is determined in the above model using the following empirical relationships.

$$
\begin{gathered}
C=0.1263 \ln (\operatorname{Re})+0.2043 \quad \operatorname{Re}<20 \\
C=0.1 \sqrt{\operatorname{Re}} \quad \operatorname{Re} \geq 20
\end{gathered}
$$

This pressure loss model was implemented with a user-defined function within STAR-CCM+.

\subsection{Ambient Temperature}

Local weather conditions for the days when the measurements were actually taken (and in the days prior to the testing) were somewhat hotter than the June average ambient assumed for the calculations. The ambient temperature at the time of testing was estimated based on weather data obtained from the National Climatic Data Center (NCDC). The maximum, minimum, and average daily temperatures recorded at the Reagan National Airport station for the day of testing and the 7 days prior are listed in 
Table 10.1. The daily average temperature on June 28, 2012, when temperature measurements were taken in both modules, was $83^{\circ} \mathrm{F}\left(28^{\circ} \mathrm{C}\right)$, with a maximum of $96^{\circ} \mathrm{F}\left(36^{\circ} \mathrm{C}\right)$ and a minimum of $70^{\circ} \mathrm{F}$ $\left(21^{\circ} \mathrm{C}\right)$. The actual temperature at the time measurements were obtained was probably close to the maximum $\left(96^{\circ} \mathrm{F}\left(36^{\circ} \mathrm{C}\right)\right)$, since the single temperature measurement in HSM-15 was taken at approximately 12:20 PM, and the measurements in HSM-1 were taken between 2:07 PM and 3:15 PM.

Table 10.1. Daily Temperature Data at Calvert Cliffs from NCDC

\begin{tabular}{|c|c|c|c|}
\hline Day & $\begin{array}{c}\text { Max Temp } \\
\left({ }^{\circ} \mathrm{F}\left({ }^{\circ} \mathrm{C}\right)\right)\end{array}$ & $\begin{array}{c}\text { Min Temp } \\
\left.\left({ }^{\circ} \mathrm{F}\left({ }^{\circ} \mathrm{C}\right)\right)\right)\end{array}$ & $\begin{array}{c}\text { Avg Temp } \\
\left.\left({ }^{\circ} \mathrm{F}\left({ }^{\circ} \mathrm{C}\right)\right)\right)\end{array}$ \\
\hline June 21, 2012 & $99(37)$ & $78(26)$ & $89(32)$ \\
\hline June 22, 2012 & $97(36)$ & $74(23)$ & $86(30)$ \\
\hline June 23, 2012 & $91(33)$ & $73(23)$ & $82(28)$ \\
\hline June 24, 2012 & $93(34)$ & $72(22)$ & $83(28)$ \\
\hline June 25, 2012 & $89(32)$ & $69(21)$ & $79(26)$ \\
\hline June 26, 2012 & $82(28)$ & $62(17)$ & $72(22)$ \\
\hline June 27, 2012 & $89(32)$ & $66(19)$ & $78(26)$ \\
\hline June 28, 2012 & $96(36)$ & $70(21)$ & $83(28)$ \\
\hline
\end{tabular}

The weather data in Table 10.1 shows that ambient conditions on June $28^{\text {th }}$ were uniformly hotter than the typical average value assumed in the pre-test calculations with the CFD models. Furthermore, the average temperature for the week leading up to June $28^{\text {th }}$ was $82^{\circ} \mathrm{F}\left(28^{\circ} \mathrm{C}\right)$. The thermal time constant of the DSC is such that the surface is expected to follow the average ambient fairly closely. Therefore, the weekly average ambient of $82^{\circ} \mathrm{F}\left(28^{\circ} \mathrm{C}\right)$ is a more reasonable estimate of the effective ambient temperature for the actual test conditions than the historical average of $77^{\circ} \mathrm{F}\left(25^{\circ} \mathrm{C}\right)$ used in the pre-test calculations.

\subsection{Post-Test Modeling Results}

The modeling changes discussed above would in general be expected to increase calculated temperatures for both the HSM-1 and HSM-15 models. Table 10.2 shows the effect of these changes on the predicted temperature at the 'under grapple ring' location, which is the only location were temperatures were measured in both modules. These results show that two of the three major changes in in the model result in significant differences between the pre-test and post-test results. Adding in the effect of the additional screens makes virtually no difference in the predicted values for the temperature at this location. This is a reasonable result, given the relatively low flow rate in the region of the 'under grapple ring' measurement. However, accounting for the higher air temperature on the day of testing raises the predicted temperatures at this location by approximately 6 degrees $\mathrm{F}$ ( $\sim 3$ degrees $\mathrm{C})$. The new information on the fuel positioning within the DSC brings the heat generating region approximately 10 inches closer to the measurement location, and increases the predicted temperatures at the measurement location by an additional 7 degrees F ( $\sim 4$ degrees $C$ ) for HSM-1 and 11 degrees F ( $\sim 6$ degrees $C$ ) for HSM-15. 
Table 10.2. Effect of Modeling Changes on Predicted Temperatures at 'Under Grapple Ring' Location

\begin{tabular}{|c|c|c|c|c|c|}
\hline \multirow[b]{2}{*}{ module } & \multirow[b]{2}{*}{$\begin{array}{c}\text { measured } \\
\text { temperature } \\
\left({ }^{\circ} \mathbf{F}\left({ }^{\circ} \mathbf{C}\right)\right) \\
\end{array}$} & \multicolumn{4}{|c|}{ Model Results } \\
\hline & & $\begin{array}{c}\text { (pre-test) } \\
\text { without } \\
\text { additional } \\
\text { screens, } 77^{\circ} \mathrm{F} \\
\text { ambient } \\
\left({ }^{\circ} \mathrm{F}\left({ }^{\circ} \mathrm{C}\right)\right) \\
\end{array}$ & $\begin{array}{c}\text { (post-test) } \\
\text { with } \\
\text { additional } \\
\text { screens, } 77^{\circ} \mathrm{F} \\
\text { ambient } \\
\left({ }^{\circ} \mathrm{F}\left({ }^{\circ} \mathrm{C}\right)\right) \\
\end{array}$ & $\begin{array}{c}\text { (post-test) } \\
\text { with } \\
\text { additional } \\
\text { screens, } 82^{\circ} \mathrm{F} \\
\text { ambient } \\
\left({ }^{\circ} \mathrm{F}\left({ }^{\circ} \mathrm{C}\right)\right) \\
\end{array}$ & $\begin{array}{c}\text { (post-test) } \\
\text { with screens, } \\
82^{\circ} \mathrm{F} \text { ambient, } \\
\text { corrected fuel } \\
\text { axial position } \\
\text { within DSC } \\
\left({ }^{\circ} \mathrm{F}\left({ }^{\circ} \mathrm{C}\right)\right) \\
\end{array}$ \\
\hline HSM-1 & $112(44)$ & $100(38)$ & $100(38)$ & $106(41)$ & $113(45)$ \\
\hline HSM-15 & $124(51)$ & $110(43)$ & $111(44)$ & $116(47)$ & 127 (53) \\
\hline
\end{tabular}

The post-test modifications to the model result in a more accurate representation of the conditions in the modules when measurements were taken. The general effect of these changes, as noted above, is to increase predicted temperatures within these systems. Table 10.3 illustrates this effect with a comparison of pre-test and post-test peak component temperatures predicted with both the HSM-1 and HSM-15 models. Table 10.4 shows a comparison of the pre-test and post-test results of the temperatures measured at the 'under grapple ring' location and the 0.0 -inch side locations on the exposed face of the DSC. These are the only measured temperatures for which there is sufficient confidence to proceed with a direct comparison between model results and the TC measurements.

Table 10.3. Maximum Temperatures from CFD Models: Pre-test and Post-test Results

\begin{tabular}{|l|c|c|c|c|}
\hline & $\begin{array}{c}\text { Concrete } \\
\text { temperature } \\
\left({ }^{\circ} \mathrm{F}\left({ }^{\circ} \mathrm{C}\right)\right)\end{array}$ & $\begin{array}{c}\mathrm{DSC} \\
\text { temperature } \\
\left({ }^{\circ} \mathrm{F}\left({ }^{\circ} \mathrm{C}\right)\right)\end{array}$ & $\begin{array}{c}\text { Fuel } \\
\text { temperature } \\
\left({ }^{\circ} \mathrm{F}\left({ }^{\circ} \mathrm{C}\right)\right)\end{array}$ & $\begin{array}{c}\text { Heat Shield } \\
\text { temperature } \\
\left({ }^{\circ} \mathrm{F}\left({ }^{\circ} \mathrm{C}\right)\right)\end{array}$ \\
\hline HSM-1 (Pre-test) & $128(53)$ & $197(92)$ & $265(129)$ & $134(57)$ \\
\hline HSM-1 (Post-test) & $133(56)$ & $208(98)$ & $279(137)$ & $143(62)$ \\
\hline HSM-15 (Pre-test) & $145(63)$ & $278(137)$ & $402(206)$ & $166(74)$ \\
\hline HSM-15 (Post-test) & $158(70)$ & $290(143)$ & $422(217)$ & $187(86)$ \\
\hline
\end{tabular}


Table 10.4. Post-Test Model Temperatures Compared to Measured Data

\begin{tabular}{|c|c|c|c|c|}
\hline & \multicolumn{4}{|c|}{ Temperature $\left({ }^{\circ} \mathrm{F}\left({ }^{\circ} \mathrm{C}\right)\right)$} \\
\cline { 2 - 5 } Temperature Location & $\begin{array}{c}\text { TC } \\
\text { measurement } \\
\text { HSM-1 }\end{array}$ & $\begin{array}{c}\text { TC } \\
\text { measurement } \\
\text { HSM-15 }\end{array}$ & $\begin{array}{c}\text { HSM-1 } \\
\text { Model } \\
\text { (post-test) }\end{array}$ & $\begin{array}{c}\text { HSM-15 } \\
\text { Model } \\
\text { (post-test) }\end{array}$ \\
\hline Under Grapple Ring & $112(44)$ & $124(51)$ & $113(45)$ & $127(53)$ \\
\hline Side $\left(0^{\circ}\right)-0.0$ inches & $108(42)$ & $\mathrm{n} / \mathrm{a}$ & $113(45)$ & $127(53)$ \\
\hline Top $\left(90^{\circ}\right)-0.0$ inches & $115(46)$ & $\mathrm{n} / \mathrm{a}$ & $116(47)$ & $133(56)$ \\
\hline Side $\left(180^{\circ}\right)-0.0$ inches & $104(40)$ & $\mathrm{n} / \mathrm{a}$ & $113(45)$ & $128(53)$ \\
\hline Rail $\left(240^{\circ}\right)-0.0$ inches & $106(41)$ & $\mathrm{n} / \mathrm{a}$ & $107(42)$ & $118(48)$ \\
\hline Rail $\left(300^{\circ}\right)-0.0$ inches & $105(41)$ & $\mathrm{n} / \mathrm{a}$ & $107(42)$ & $118(48)$ \\
\hline
\end{tabular}

The increased temperatures due to the more realistic modeling for HSM-1 do not have the effect of improving the comparison with the measured temperatures from the side of the canister. These results are shown graphically in Figure 10.1 for the top, sides and rail locations on the DSC. Figures 10.2 through 10.4 show this comparison for each location individually, since the curves in Figure 10.1 are relatively close together and difficult to separate near the DSC base.

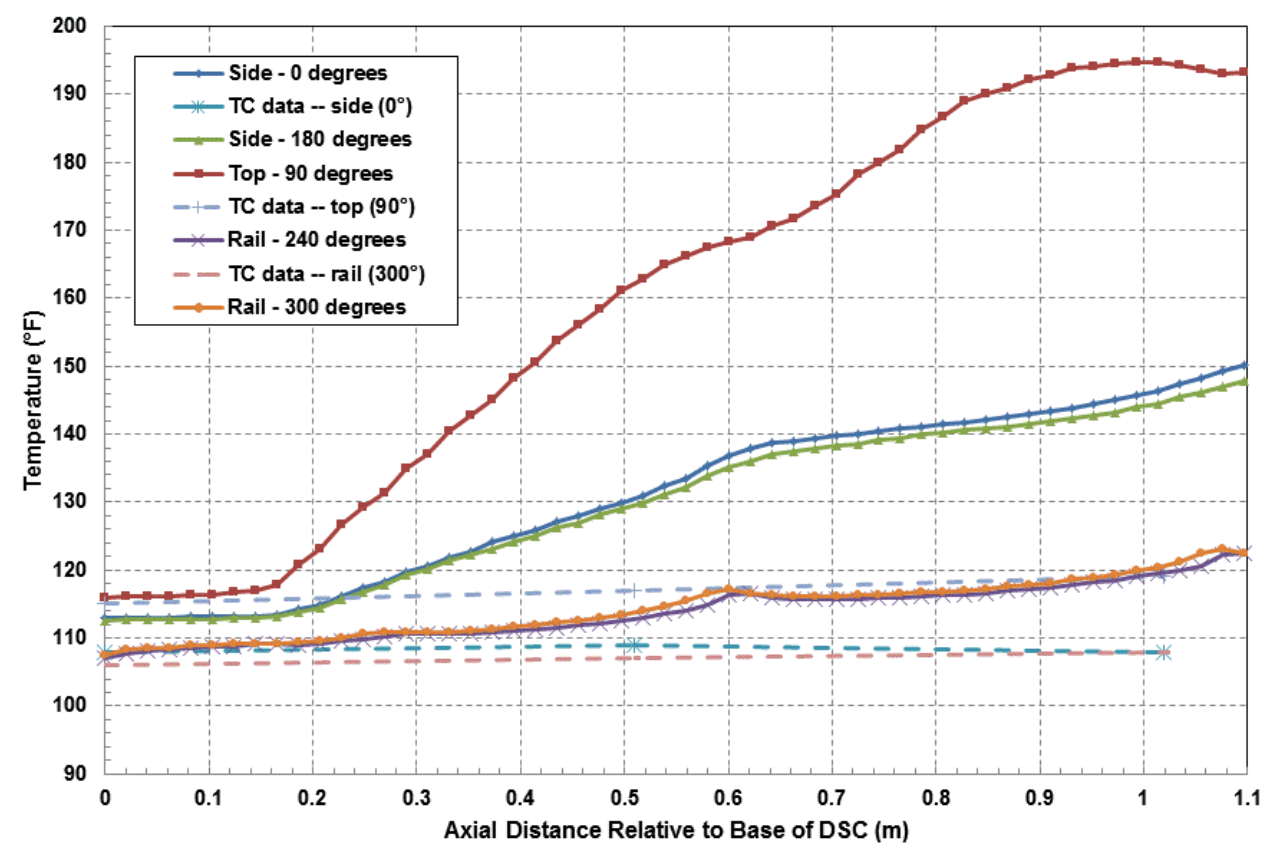

Figure 10.1. Comparison of Measured to (Post-test) Predicted Axial Temperatures on DSC Surface in HSM-1 


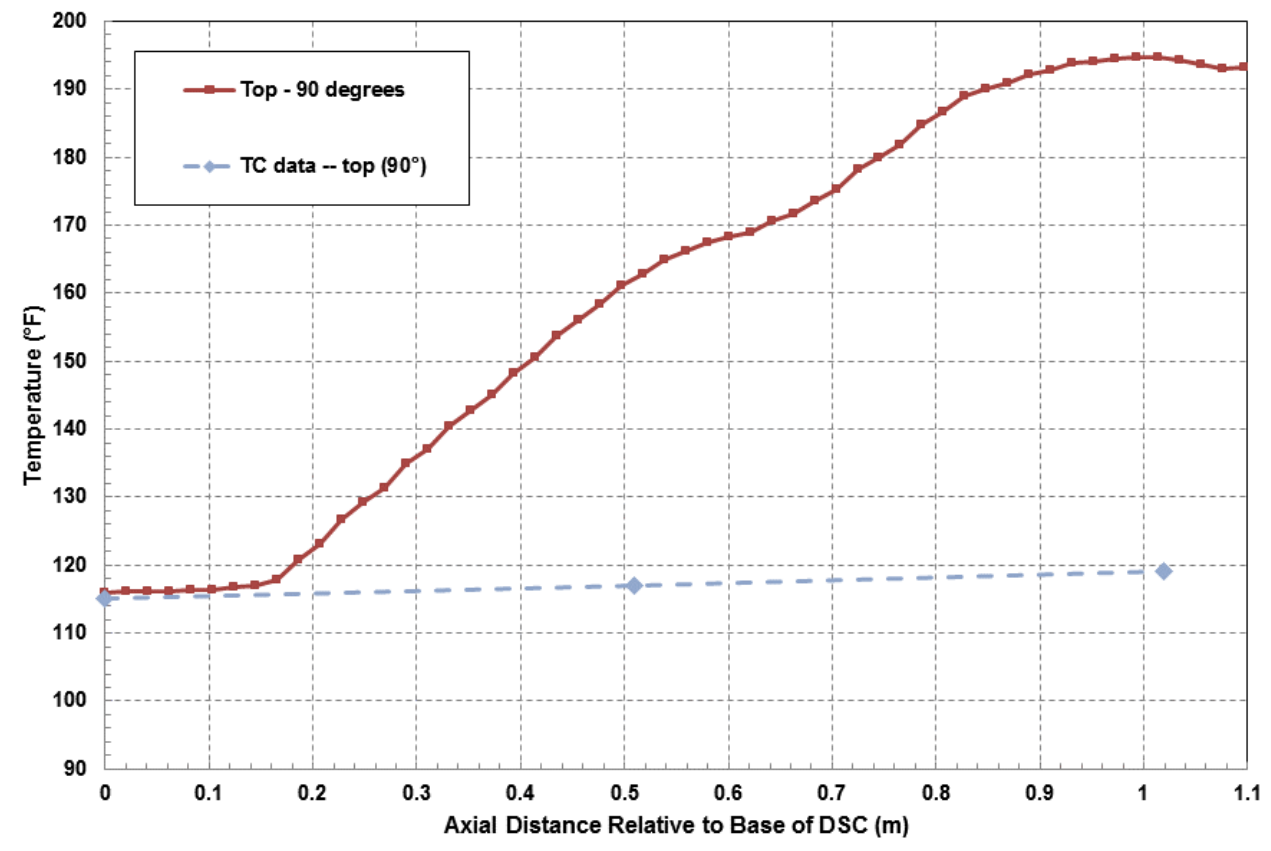

Figure 10.2. Axial Temperature Comparison at Top of DSC in HSM-1

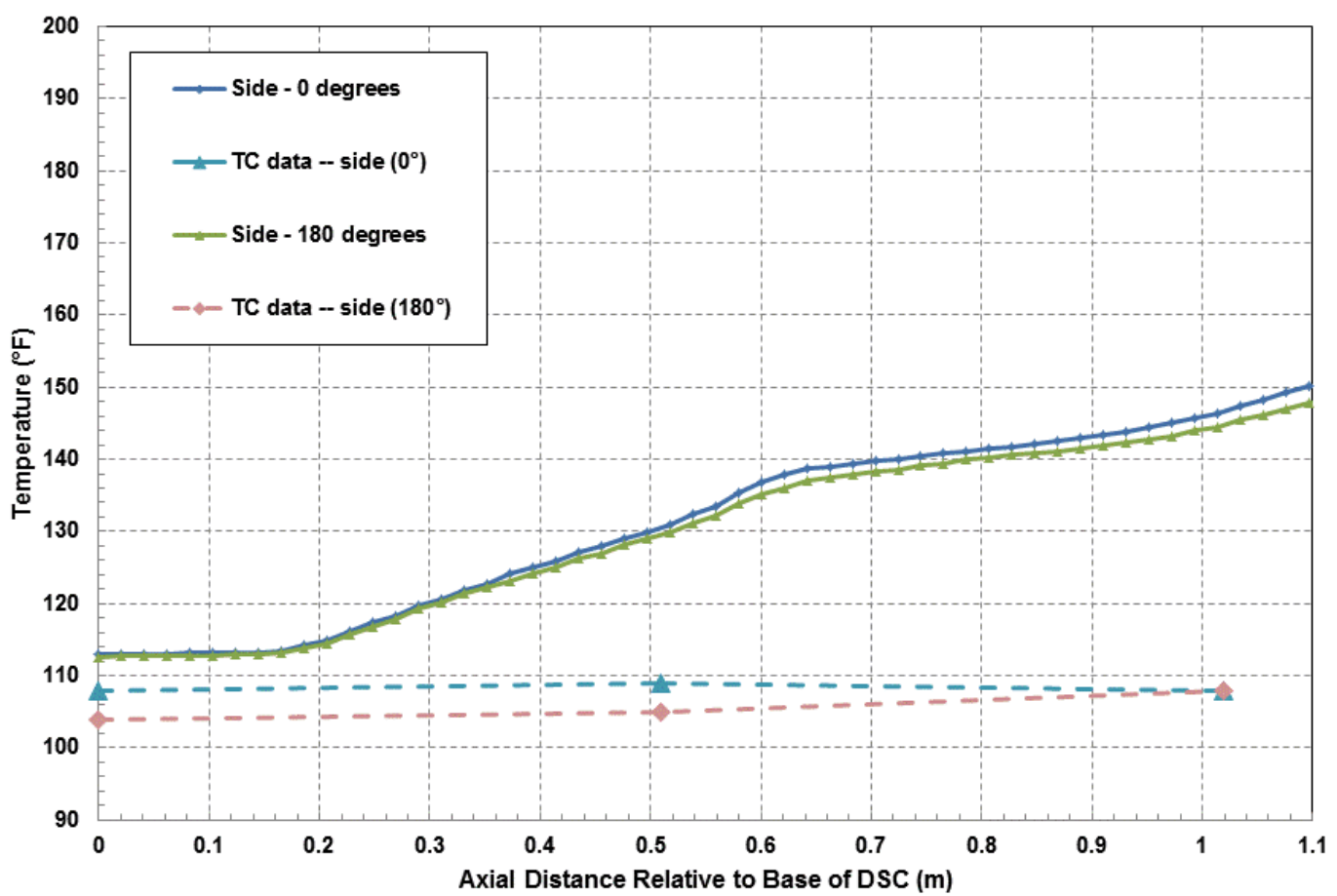

Figure 10.3. Axial Temperature Comparison on Sides of DSC in HSM-1 


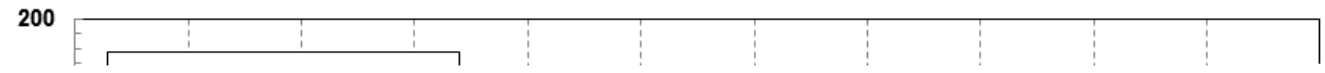

Figure 10.4. Axial Temperature Comparison at Support Rail Locations for DSC in HSM-1

The plots in Figures 10.1 through 10.4 show that the HSM-1 model predictions are in reasonable agreement with the measured temperatures near the base of the DSC. However, in the model results, the axial distance with a relatively flat temperature gradient extends only about $0.2 \mathrm{~m}$ ( 8 inches) in from the base, rather than the $\sim 1 \mathrm{~m}$ ( $\sim 40$ inches) distance measured on the DSC in the HSM-1 module. The relatively cold measured temperatures reported for the DSC surface locations at 20 inches $(0.51 \mathrm{~m})$ and 40 inches $(1.02 \mathrm{~m})$ are not consistent with the axial distribution of decay heat in the fuel rods and the total decay heat load in the DSC.

If these measured temperatures were accurate representations of the surface temperature gradient over the lower fourth of the DSC, then the internal component temperatures within the DSC would have to be much higher than predicted with this CFD model of the DSC in HSM-1, in order to remove the same decay heat load. As discussed above, this indicates that these temperature measurements are not representative of the axial temperature distribution on the side of the DSC at distances of 20 inches $(0.51$ $\mathrm{m})$ and 40 inches $(1.02 \mathrm{~m})$ from the DSC base. Given the difficulty of obtaining the temperature measurements on the side of the DSC, reaching through the narrow space between the DSC shell and the bore, it seems quite likely that the TC probe was not able to make good contact with the DSC surface. Figure 10.5 compares the measured temperatures for the top surface of the DSC with predicted air temperatures in the region just above the DSC, and the temperature of the heat shield. This plot shows that it is quite reasonable to suppose that the measured temperatures at 20 inches $(0.51 \mathrm{~m})$ and 40 inches $(1.02 \mathrm{~m})$ are air temperatures, not DSC surface temperatures. 


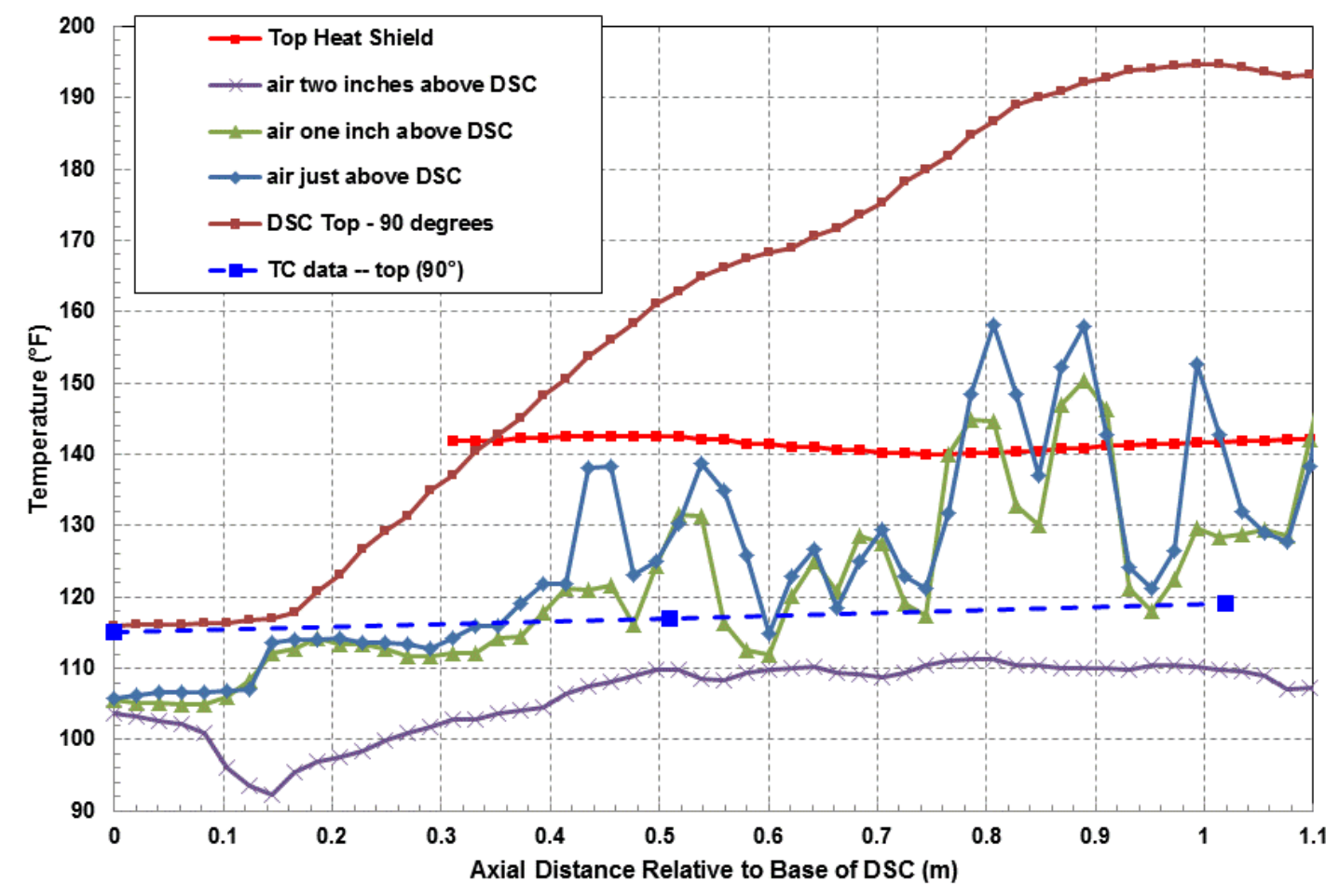

Figure 10.5. Axial Temperature Comparison for Top Heat Shield, Air Above DSC, and DSC Top Surface in HSM-1

\subsection{Post-Test Fuel Region Modeling Evaluations}

Package end temperatures are not usually an area of concern in evaluations of spent fuel storage systems, and variations in the axial effective conductivity of the fuel assembly are generally neglected. However, in this case, with the single reliable temperature measurement on the base of the DSC (at the 'under grapple ring' location, as discussed above), the modeling approach used to represent the effective axial conductivity of the fuel took on unusual importance. To evaluate the sensitivity of overall results to this aspect of the model, two additional cases were evaluated. In the first case, the axial effective conductivity was modified to capture the effect of the fuel assembly end fittings. In the second case, the fuel effective conductivity was modified to represent only the fuel region (including the end fittings), and the guide sleeves were modeled explicitly, using a non-conformal meshing approach.

For the explicitly modeled guide sleeve case, a separate meshing continua for the guide sleeves was specified within the STAR-CCM+ model. This allowed meshing without a conformal interface between each mesh continua. For a conformal mesh, the nodes at the boundaries are shared across regions, but for a non-conformal mesh the boundary nodes are independent and require an averaging algorithm to connect the two regions. This approach avoids meshing difficulties created when very thin components are treated as part of the conformal mesh. Interface boundaries joined the non-conformal mesh regions together, and ensured that conservation principles were applied at these boundaries. 
Table 10.5 illustrates the results obtained for these two cases, comparing the predicted temperatures at the 'under grapple ring' measurement location, and the peak fuel cladding temperatures. These results show that with increased refinement of the modeling of the fuel region, the predicted 'under grapple ring' temperature increases slightly. This is consistent with the expectation that the measured temperatures are slightly low, compared to temperatures that would exist at this location with the module lid in place and airflow around the DSC undisturbed. More significantly, refinement of the fuel region tends to result in lower predicted peak cladding temperatures, as the inherent conservatism in the homogeneous fuel effective conductivity model is reduced due to more accurate modeling of the fuel region geometry.

Table 10.5. Results of Fuel Region Modeling Evaluations

\begin{tabular}{|c|c|c|c|c|}
\hline \multirow[b]{2}{*}{ Module/location } & \multicolumn{4}{|c|}{ Temperature $\left({ }^{\circ} \mathrm{F}\left({ }^{\circ} \mathrm{C}\right)\right)$} \\
\hline & $\begin{array}{c}\mathrm{TC} \\
\text { measurement }\end{array}$ & (post-test) & $\begin{array}{c}\text { modified } \\
\text { axial } \\
\text { effective } \\
\text { conductivity }\end{array}$ & $\begin{array}{c}\text { guide } \\
\text { sleeves } \\
\text { meshed }\end{array}$ \\
\hline \multicolumn{5}{|l|}{ HSM-1 } \\
\hline under grapple ring & $112(44)$ & $113(45)$ & $120(49)$ & $117(47)$ \\
\hline peak fuel cladding & $\mathrm{n} / \mathrm{a}$ & $279(137)$ & $271(133)$ & $262(128)$ \\
\hline \multicolumn{5}{|l|}{ HSM-15 } \\
\hline under grapple ring & $124(51)$ & $127(53)$ & $138(59)$ & $134(57)$ \\
\hline peak fuel cladding & $\mathrm{n} / \mathrm{a}$ & $422(217)$ & $412(211)$ & $398(203)$ \\
\hline
\end{tabular}





\subsection{Conclusions}

The results obtained in this study show that existing CFD modeling tools can be used to obtain reasonable and accurate detailed models of spent fuel storage systems with realistic decay heat loadings. The differences between the pre-test and post-test results illustrate the importance of accurate and complete information on the as-built configuration of the system, and on the magnitude and distribution of decay heat load in the fuel assemblies stored in the specific module. 



\subsection{References}

10 CFR 71. 2003. "Packaging and Transportation of Radioactive Material." Code of Federal Regulations, U.S. Nuclear Regulatory Commission, Washington D.C.

Bahney III, RH and TL Lotz. 1996. Spent Nuclear Fuel Effective Thermal Conductivity Report. BBA000000-01717-5705-00010 Rev. 00, TRW Environmental Safety Systems, Inc., Fairfax, Virginia.

CD-Adapco. 2012. STAR-CCM+ 7.02.011 (computer software). CD-Adapco, Melville, New York.

Dassault Systemes SolidWorks ${ }^{\circledR}$ Corp. 2011. SolidWorks ${ }^{\circledR}$ Premium 2011 x64 Edition (computer software). Dassault Systemes, Waltham, Massachusetts.

DOE/RW-0472. 1998. Topical Report on Actinide-Only Burnup Credit for PWR Spent Nuclear Fuel Packages. DOE/RW-0472, Revision 2, Office of Civilian Radioactive Waste Management, Washington D.C..

Gauld IC, SM Bowman, and JE Horwedel. 2009. ORIGEN-ARP: Automatic Rapid Processing for Spent Fuel Depletion, Decay, and Source Term Analysis. ORNL/TM-2005/39, Oak Ridge National Laboratory, Oak Ridge, Tennessee.

Guyer EC. 1989. Handbook of Applied Thermal Design, McGraw-Hill, New York City, New York.

Holman JP. 1997. Heat Transfer.8th ed. McGraw-Hill, New York City, New York.

Incropera FP, DP Dewitt, TL Bergman, and AS Lavine. 2007. Fundamentals of Heat and Mass Transfer. 6th ed. John Wiley \& Sons, Hoboken, NJ.

ISOE - Information System on Occupational Exposure. 2012. "Calvert Cliffs Dry Fuel Storage and Industry Lessons Learned." Presentation by P. Jones of Calvert Cliffs Nuclear Power Plant. Accessed September 11, 2012 at http://www.isoe-network.net/index.php/component/docman/cat_view/411-fortlauderdale-usa-january-2010/412-slides/419-session-vii-outages-lessons-learned-alara-goals.html.

Michener TE, DR Rector, JM Cuta, RE Dodge, and CW Enderlin. 1995. COBRA-SFS: A ThermalHydraulic Code for Spent Fuel Storage and Transportation Casks. PNL-10782, Pacific Northwest National Laboratory, Richland, Washington.

Perry RH, and DW Green. 1997. Perry’s Chemical Engineers' Handbook. 7th ed. McGraw-Hill, New York City, NY.

U. S. HCN. 2000. "U.S. Historical Climatology Network (U.S. HCN) Monthly Data, Version 2, United States Historical Climatology Network (HCN) Serial Temperature and Precipitation Data." National Oceanic and Atmospheric Administration, National Climate Data Center, Asheville, North Carolina. Downloaded on April 22, 2012 from ftp://ftp.ncdc.noaa.gov/pub/data/ushcn/v2/monthly. 

Appendix A

\section{Material Properties}





\section{Appendix A}

\section{Material Properties}

Table A.1 list the bill of material for the SolidWorks ${ }^{\circledR}$ CAD model. The material properties defined within the STAR-CCM model are listed in Tables A.2 through A.4. The effective fuel conductivity is listed in Table A-5.

Constant properties were assumed for the solid parts and variable temperature dependent properties were defined for the fluid regions. The air viscosity and thermal conductivity was calculated within STAR-CCM+ using Sutherland's law (A.1).

$$
\frac{x}{x_{0}}=\left(\frac{T}{T_{0}}\right)^{\frac{3}{2}}\left(\frac{T_{0}+S}{T+S}\right)
$$

Where;

$$
\begin{aligned}
& x=\text { calculated property } \\
& x_{0}=\text { reference property } \\
& T=\text { temperature }(\mathrm{K}) \\
& T_{0}=\text { reference temperature }(\mathrm{K}) \\
& S=\text { Sutherland Constant }(\mathrm{K})
\end{aligned}
$$

The relationship in Eq. (A.1) was also used to calculate the viscosity for helium. However, due to inconsistencies in the implementation of this relationship for helium properties, the thermal conductivity of helium was specified within STAR-CCM+ by a user defined input table (Incropera et al., 2007). The temperature dependent values are listed in Table A.4.

The specific heat for air was calculated using the built in 'Polynomial in T' function, and the 'Thermodynamic Polynomial Data' function was used to determine the specific heat of helium. Both of these functions use a series of coefficients to construct a temperature versus specific heat curve. For both air and helium the default coefficients within STAR-CCM+ were used.

Table A.1. EPRI SolidWorks Model Bill of Materials

\begin{tabular}{|c|c|c|c|c|}
\hline $\begin{array}{c}\text { ITEM } \\
\text { NO. }\end{array}$ & PART NUMBER & DESCRIPTION & MATERIAL & QTY. \\
\hline 1 & Concrete Pad_Inner Cell & & Concrete & 1 \\
\hline 2 & Concrete Wall_Inner Cell & & Concrete & 2 \\
\hline 3 & Concrete Ceiling_Inner Cell & & Concrete & 1 \\
\hline 4 & Lower Vent_PreCast Slab & & Concrete & 1 \\
\hline 5 & PreCast Concrete Slab & & Concrete & 1 \\
\hline 6 & Plate MK. P-2 & & Carbon Steel & 2 \\
\hline 7 & Plate MK.P-1 & & Carbon Steel & 2 \\
\hline 8 & W8x48x6ft7in & & Carbon Steel & 2 \\
\hline
\end{tabular}




\begin{tabular}{|c|c|c|c|c|}
\hline $\begin{array}{c}\text { ITEM } \\
\text { NO. }\end{array}$ & PART NUMBER & DESCRIPTION & MATERIAL & QTY. \\
\hline 9 & $0.75 \mathrm{in} x 9 \mathrm{in} \times 10.5 \mathrm{in}$ & & Carbon Steel & 4 \\
\hline 10 & W8x40x14ft4.5in & & Carbon Steel & 2 \\
\hline 11 & linx 2 in $x 9$ in & & Carbon Steel & 4 \\
\hline 12 & BasePlate 0.5 inx6inx $16 \mathrm{ft} 10 \mathrm{in}$ & & Carbon Steel & 2 \\
\hline 13 & RailPlate_0.25inx3inx $16 \mathrm{ft} 8.25 \mathrm{in}$ & & Carbon Steel & 2 \\
\hline 14 & RailStop_6inx6inx 1 inx6inlong & & Carbon Steel & 2 \\
\hline 15 & HSM Access Sleeve MK. AS-1 & & Carbon Steel & 1 \\
\hline 16 & Plate_0.75inx7inx $8 \mathrm{ft}$ & & $\begin{array}{c}\text { Stainless } \\
\text { Steel }\end{array}$ & 1 \\
\hline 17 & L7x4x0.75x7ft11 in & & Carbon Steel & 1 \\
\hline 18 & Plate_0.75inx6inx7ft7in & & $\begin{array}{c}\text { Stainless } \\
\text { Steel }\end{array}$ & 2 \\
\hline 19 & L7x $4 \times 0.75 \times 7 f t 6$ in & & Carbon Steel & 2 \\
\hline 20 & L9x4x0.625x $2 \mathrm{ft}$ & & Carbon Steel & 4 \\
\hline 21 & Plate $1.75 \mathrm{inx} 7 \mathrm{ft} 5.5 \mathrm{inx} 7 \mathrm{ft} 5.5 \mathrm{in}$ & & Carbon Steel & 1 \\
\hline 22 & Plate $0.5 \mathrm{in} \times 12 \mathrm{in} \times 7 \mathrm{ft} 6 \mathrm{in}$ & & Carbon Steel & 4 \\
\hline 23 & Plate 0.25 inx $7 \mathrm{ft} 6.25 \mathrm{in} \times 7 \mathrm{ft} 6.25$ in & & Carbon Steel & 1 \\
\hline 24 & Lifting Tab & & Carbon Steel & 2 \\
\hline 25 & Concrete Backwall & & Concrete & 1 \\
\hline 26 & HS-2 & Heat Shield & $\begin{array}{c}\text { Stainless } \\
\text { Steel } \\
\end{array}$ & 1 \\
\hline 27 & HS-3 & Heat Shield & $\begin{array}{c}\text { Stainless } \\
\text { Steel } \\
\end{array}$ & 1 \\
\hline 28 & HS-1 & Heat Shield & $\begin{array}{c}\text { Stainless } \\
\text { Steel }\end{array}$ & 2 \\
\hline 29 & HS-4 & Heat Shield & $\begin{array}{c}\text { Stainless } \\
\text { Steel }\end{array}$ & 4 \\
\hline 30 & Dry fuel Cask & DSC & $\begin{array}{c}\text { Stainless } \\
\text { Steel } \\
\end{array}$ & 1 \\
\hline 31 & Door Concrete & & Concrete & 1 \\
\hline 35 & Spacer_Disk & & Carbon Steel & 9 \\
\hline 36 & Support_Rod & & $\begin{array}{c}\text { Stainless } \\
\text { Steel } \\
\end{array}$ & 4 \\
\hline 37 & Guide_Sleeve & & $\begin{array}{c}\text { Stainless } \\
\text { Steel }\end{array}$ & 24 \\
\hline 38 & NonActive_Fuel_B & & Fuel & 24 \\
\hline 39 & Active_Fuel & & Fuel & 24 \\
\hline 40 & NonActive_Fuel_T & & Fuel & 24 \\
\hline 41 & BottomCap & & Carbon Steel & 1 \\
\hline 42 & ТорСар & & Carbon Steel & 1 \\
\hline
\end{tabular}


Table A.2. Solid Region Properties

\begin{tabular}{|c|c|c|c|}
\hline Material & $\begin{array}{c}\text { Density } \\
\left(\mathrm{kg} / \mathrm{m}^{3}\right)\end{array}$ & $\begin{array}{c}\text { Specific } \\
\text { Heat } \\
(\mathrm{J} / \mathrm{kg}-\mathrm{K})\end{array}$ & $\begin{array}{c}\text { Thermal } \\
\text { Conductivity } \\
(\mathrm{W} / \mathrm{m}-\mathrm{K})\end{array}$ \\
\hline Carbon Steel & 7832 & 434 & 63.9 \\
\hline Concrete & 2240 & 750 & 0.53 \\
\hline Fuel & 7928.16 & 281.8 & see Table A.5 \\
\hline Stainless Steel & 8055 & 480 & 15.1 \\
\hline
\end{tabular}

Table A.3. Air Properties for Module Fluid Region: Calculated from Sutherland's Law

\begin{tabular}{|l|c|c|c|c|c|c|}
\hline \multirow{4}{*}{} & \multicolumn{3}{|c|}{$\begin{array}{c}\text { Dynamic Viscosity } \\
(\mathrm{Pa}-\mathrm{s})\end{array}$} & \multicolumn{3}{c|}{ Thermal Conductivity } \\
& \multicolumn{3}{|c|}{$\left.\mathrm{W}_{\mathrm{m}}-\mathrm{K}\right)$} \\
\cline { 2 - 7 } & $\mathrm{T}_{0}$ & $\mathrm{u}_{0}$ & $\mathrm{~S}$ & $\mathrm{~T}_{0}$ & $\mathrm{k}_{0}$ & $\mathrm{~S}$ \\
Material & $(\mathrm{K})$ & $(\mathrm{Pa}-\mathrm{s})$ & $(\mathrm{K})$ & $(\mathrm{K})$ & $(\mathrm{W} / \mathrm{m}-\mathrm{K})$ & $(\mathrm{K})$ \\
\hline Air & 273.15 & $1.72 \mathrm{E}-05$ & 111.0 & 273.15 & 0.02414 & 194.0 \\
\hline
\end{tabular}

Table A.4. Thermal Properties for Helium

\begin{tabular}{|c|c|c|}
\hline $\begin{array}{c}\text { Temperature } \\
(\mathrm{K})\end{array}$ & $\begin{array}{c}\text { Dynamic } \\
\text { Viscosity } \\
(\text { Pa-s })\end{array}$ & $\begin{array}{c}\text { Thermal } \\
\text { Conductivity } \\
(\mathrm{W} / \mathrm{m}-\mathrm{K})\end{array}$ \\
\hline 100 & $96.3 \mathrm{E}-07$ & 0.073 \\
\hline 120 & $107 \mathrm{E}-07$ & 0.0819 \\
\hline 140 & $118 \mathrm{E}-07$ & 0.0907 \\
\hline 160 & $129 \mathrm{E}-07$ & 0.0992 \\
\hline 180 & $139 \mathrm{E}-07$ & 0.1072 \\
\hline 200 & $150 \mathrm{E}-07$ & 0.1151 \\
\hline 220 & $160 \mathrm{E}-07$ & 0.1231 \\
\hline 240 & $170 \mathrm{E}-07$ & 0.13 \\
\hline 260 & $180 \mathrm{E}-07$ & 0.137 \\
\hline 280 & $190 \mathrm{E}-07$ & 0.145 \\
\hline 300 & $199 \mathrm{E}-07$ & 0.152 \\
\hline 350 & $221 \mathrm{E}-07$ & 0.17 \\
\hline 400 & $243 \mathrm{E}-07$ & 0.187 \\
\hline 450 & $263 \mathrm{E}-07$ & 0.204 \\
\hline 500 & $283 \mathrm{E}-07$ & 0.22 \\
\hline 600 & $320 \mathrm{E}-07$ & 0.252 \\
\hline 650 & $332 \mathrm{E}-07$ & 0.264 \\
\hline 700 & $350 \mathrm{E}-07$ & 0.278 \\
\hline 750 & $364 \mathrm{E}-07$ & 0.291 \\
\hline 800 & $382 \mathrm{E}-07$ & 0.304 \\
\hline & & \\
\hline
\end{tabular}




\begin{tabular}{|c|c|c|}
\hline $\begin{array}{c}\text { Temperature } \\
(\mathrm{K})\end{array}$ & $\begin{array}{c}\text { Dynamic } \\
\text { Viscosity } \\
(\mathrm{Pa}-\mathrm{s})\end{array}$ & $\begin{array}{c}\text { Thermal } \\
\text { Conductivity } \\
(\mathrm{W} / \mathrm{m}-\mathrm{K})\end{array}$ \\
\hline 900 & $414 \mathrm{E}-07$ & 0.33 \\
\hline 1000 & $446 \mathrm{E}-07$ & 0.354 \\
\hline
\end{tabular}

Table A.5. Effective Fuel Thermal Conductivity Based on Ft. Calhoun CE14x14

\begin{tabular}{|c|c|c|c|c|}
\hline \multicolumn{3}{|c|}{ Temperature } & \multicolumn{3}{c|}{ Fuel keff for standard CE14x14 (estimated) } \\
\hline$(\mathrm{F})$ & $(\mathrm{K})$ & $(\mathrm{Btu} / \mathrm{min}-\mathrm{in}-\mathrm{F})$ & $(\mathrm{Btu} / \mathrm{hr}-\mathrm{ft}-\mathrm{F})$ & $(\mathrm{W} / \mathrm{m}-\mathrm{K})$ \\
\hline 150 & 338.7 & 0.000327007 & 0.235445255 & 0.407220699 \\
\hline 200 & 366.5 & 0.000345693 & 0.24889927 & 0.430490453 \\
\hline 300 & 422 & 0.000411095 & 0.295988321 & 0.511934593 \\
\hline 400 & 477.6 & 0.000504526 & 0.363258394 & 0.628283364 \\
\hline 500 & 533.1 & 0.000607299 & 0.437255474 & 0.756267012 \\
\hline 600 & 588.7 & 0.000719416 & 0.517979562 & 0.895885537 \\
\hline 700 & 644.3 & 0.000850219 & 0.612157664 & 1.058773816 \\
\hline 800 & 699.8 & 0.000990365 & 0.713062774 & 1.233296973 \\
\hline
\end{tabular}

Using the values listed in Table A.5, an equation to calculate the effective thermal conductivity based on temperature was determined. The resulting plot and equation are shown in Figure A.1. This equation was used to create a user defined field function in the STAR-CCM+ model for the radial thermal conductivity of the fuel regions. The field function calculated the thermal conductivity of each cell within the fuel regions based upon the temperature of that cell.

The axial thermal conductivity of the fuel regions was computed based on the mass-weighted average of the constituent materials of the region, which included the guide sleeves and zicaloy cladding. It was assumed that at the bottom of the fuel region, the effective conductivity representing the space between the fuel pins and bottom plug was calculated from the mass-weighted average of the guide sleeves and helium. Figure A.2 plots the resulting axial thermal conductivity versus temperature, and shows the equations used for the axial thermal conductivity field function for the fuel regions. The field function calculated the axial conductivity of each cell within the fuel regions based upon temperature and axial location. 


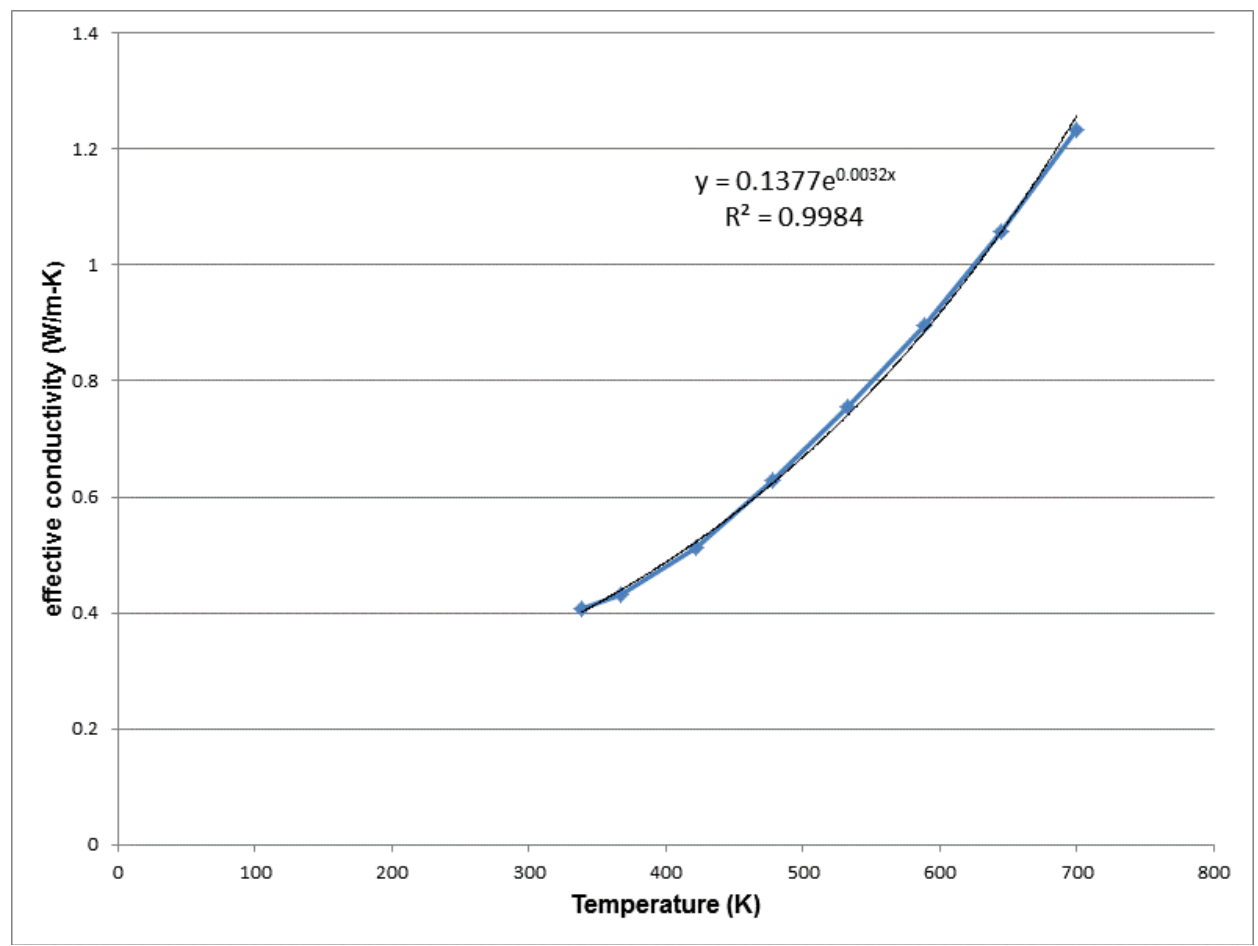

Figure A.1. Effective Radial Conductivity for Active Fuel Region

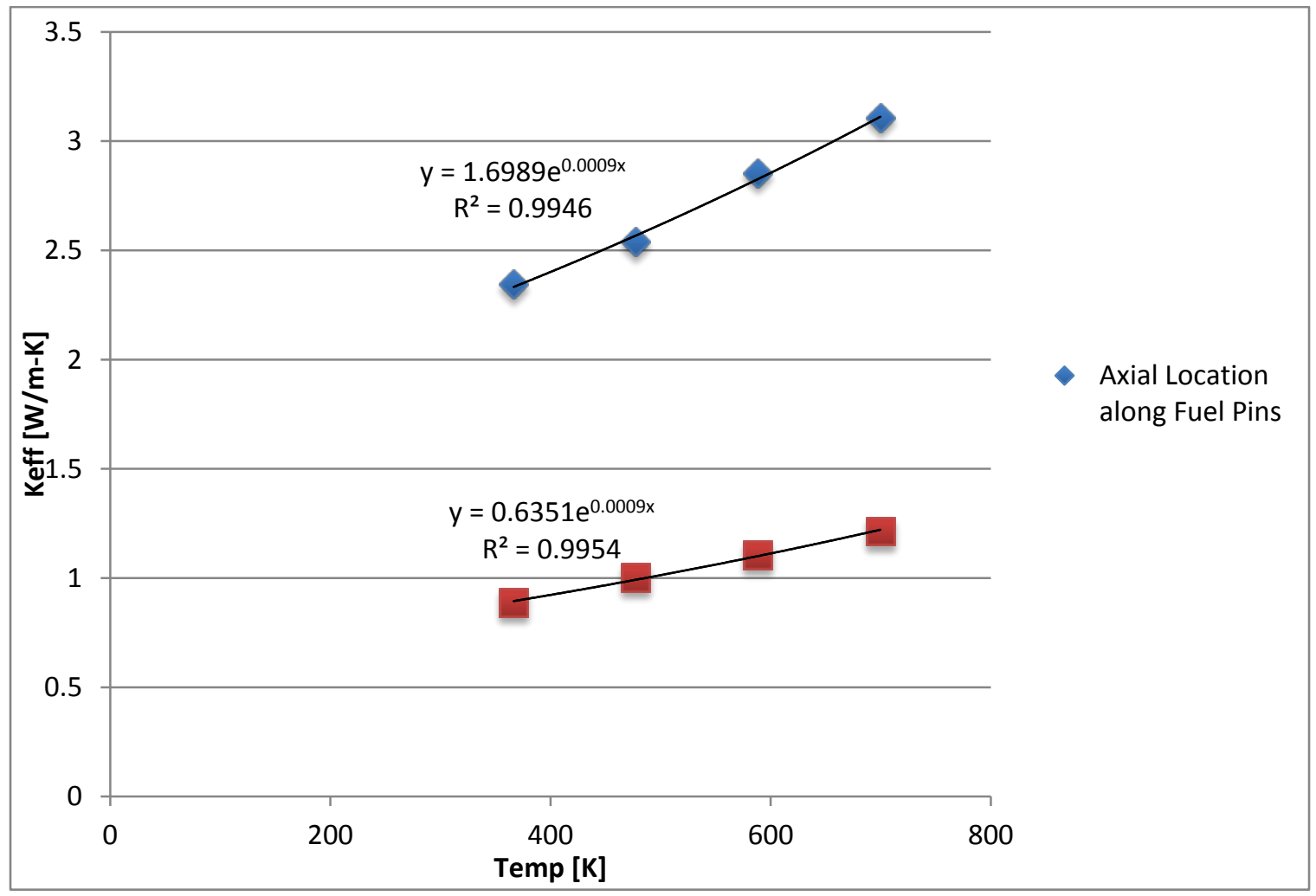

Figure A.2. Effective Axial Conductivity for Active Fuel Region 

Appendix B

\section{External Heat Transfer Model}





\section{Appendix B}

\section{External Heat Transfer Model}

The heat transfer coefficient due to convection between the external surfaces of the module and the environment was calculated based of the Nusselt number $(\mathrm{Nu})$, which is the non-dimensional ratio of the convection and conduction heat transfer coefficients.

$$
N u=\frac{h L}{k}
$$

Where;

$\mathrm{Nu}=$ Nusselt number

$\mathrm{h}=$ convection coefficient

$\mathrm{L}=$ critical length

$\mathrm{k}=$ thermal conductivity of the fluid

The critical length for each surface corresponded to the either the horizontal or vertical length of the surface, depending on the orientation of the surface (i.e. horizontal or vertical). The natural convection correlations used to calculate the Nusselt number are presented below (Guyer, 1989). All external surfaces were considered either a vertical or horizontal flat plate.

\section{Vertical Flat Plates:}

The overall Nusselt number for flow over a vertical flat surface is computed from the Nusselt numbers for laminar $\left(N u_{i}\right)$ and turbulent flow $\left(N u_{t}\right)$ :

$$
\begin{gathered}
N u=\left[N u_{l}^{6}+N u_{t}^{6}\right]^{1 / 6} \\
N u_{l}=\frac{2.8}{\ln \left[1+2.8 /\left(C_{l} R a^{1 / 4}\right)\right]} \\
N u_{t}=C_{v} R a^{1 / 3} \\
C_{l}=\frac{0.671}{\left[1+(0.492 / \operatorname{Pr})^{9 / 16}\right]^{4 / 9}} \\
C_{v}=\frac{0.13 \operatorname{Pr}^{0.22}}{\left(1+0.61 \operatorname{Pr}^{0.81}\right)^{0.42}}
\end{gathered}
$$


Where;

$\mathrm{Ra}=$ Rayleigh number

$\operatorname{Pr}=$ Prandtl number of fluid

Equations B.2-B.6 are valid for a Rayleigh number in the range $1<\mathrm{Ra}<10^{12}$.

\section{Horizontal Flat Plates:}

The overall Nusselt number for an upward facing horizontal plate are listed below:

$N u=\left[N u_{l}^{10}+N u_{t}^{10}\right]^{/ 10}$

$N u_{l}=\frac{1.4}{\ln \left[1+1.677\left(C_{l} R a^{1 / 4}\right)\right]}$

$N u_{t}=0.14 R a^{1 / 3}$

Where $C_{l}$ is defined in Equation (B.5). Equation (B.7) is valid for a Rayleigh number in the range $\mathrm{Ra}>1$. 
Appendix C

Sensitivity Studies 



\section{Appendix C}

\section{Sensitivity Studies}

\section{Resistance Boundary between Spacer Disk and DSC}

As described in Section 5.2, a uniform gap was assumed, as a modeling simplification, in pre-test versions of the model. To investigate the effect of the circumferentially non-uniform contact between the spacer disks and the DSC shell, the gap between disk edge and shell was varied as a function of radial position. The post-test model includes a more realistic geometry that assumes zero gap between the circular spacer disk and cylindrical DSC shell along the bottom interface, with the gap increasing radially to the maximum value at the top interface. Figure C.1 shows how the gap between these components changes in relation to the angle (theta) along the cylindrical surface of the DSC. In this plot, $0^{\circ}$ corresponds to the right side of the DSC, resulting in the maximum gap occurring at $90^{\circ}$ (the top of the DSC) and the minimum at $270^{\circ}$ (the bottom of the DSC).

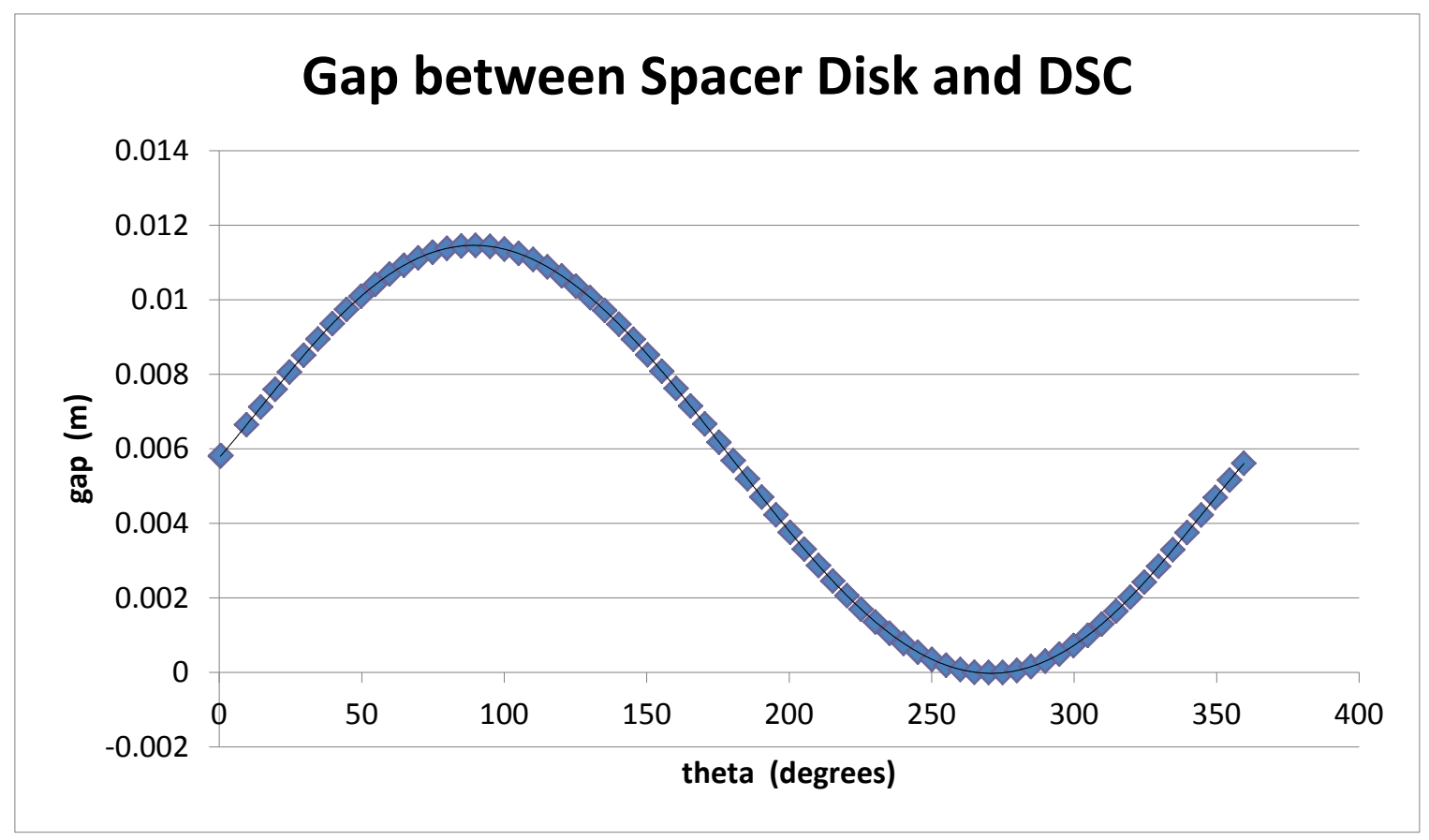

Figure C.1. Gap Between Spacer Disk and DSC in Relation to the Cylindrical Angle of the DSC

This model modification accounts only for the geometry effect of the reduced gap in the lower half of the DSC (and increased gap in the upper half.) Modifications to quantify the increased contact conductance that would result from the massive weight of the package internals pressing down on the lower portion of the DSC shell are beyond the scope of this study. The contact resistance is based on simple tolerance fit between components, as described in Section 5.2. This approach would tend to 
underestimate the contact conductance in the lower region, and further studies would be required to fully characterize the effect on shell temperature distributions.

The model modification was implemented with a user-defined function within STAR-CCM+, based on the relationship in Eq. (5.1). This function computes the circumferentially varying contact resistance, with the gap, L, changing along the inner surface of the DSC as shown in Figure C.1. The effect of this modification is illustrated in Table C.1, comparing the peak component temperatures predicted with the uniform gap assumption and the non-uniform gap assumption. These cases were run with the post-test modifications to account for the additional inlet/outlet screens, and with ambient temperature of $82^{\circ} \mathrm{F}$ $\left(28^{\circ} \mathrm{C}\right)$.

Table C.1. Maximum Temperatures from CFD Models: Uniform and Non-uniform Gap Results

\begin{tabular}{|c|c|c|c|c|}
\hline \multirow{2}{*}{} & \multicolumn{2}{|c|}{ HSM-1 } & \multicolumn{2}{c|}{ Model } \\
\cline { 2 - 5 } & $\begin{array}{c}\text { uniform } \\
\text { gap } \\
\left({ }^{\circ} \mathrm{F}\left({ }^{\circ} \mathrm{C}\right)\right)\end{array}$ & $\begin{array}{c}\text { non-uniform } \\
\text { gap } \\
\left({ }^{\circ} \mathrm{F}\left({ }^{\circ} \mathrm{C}\right)\right)\end{array}$ & $\begin{array}{c}\text { uniform } \\
\text { gap } \\
\left({ }^{\circ} \mathrm{F}\left({ }^{\circ} \mathrm{C}\right)\right)\end{array}$ & $\begin{array}{c}\text { non- } \\
\text { uniform gap } \\
\left({ }^{\circ} \mathrm{F}\left({ }^{\circ} \mathrm{C}\right)\right)\end{array}$ \\
\hline Component & $133(56)$ & $133(56)$ & $151(66)$ & $151(66)$ \\
\hline DSC shell & $206(97)$ & $204(96)$ & $276(136)$ & $278(137)$ \\
\hline Fuel & $273(134)$ & $274(134)$ & $409(209)$ & $411(211)$ \\
\hline Heat Shield & $144(62)$ & $140(60)$ & $172(78)$ & $171(77)$ \\
\hline
\end{tabular}

These results show that changes in the circumferential distribution of contact resistance can have some effect on peak component temperatures. As might be expected, the effect is larger at the higher decay heat load, since the thermal gradients are steeper, and therefore more sensitive to variations in thermal resistance along any path between the fuel and the DSC outer shell. However, the circumferential variation in contact resistance tends to have more of an effect on the temperature distribution with the DSC and on the DSC shell surface than on the overall peak component temperatures, since the total amount of heat that must be removed remains unchanged.

\section{Bounding Assumption of No Helium Convection within DSC}

Natural convection of the helium within the DSC is one of three heat transfer modes that remove heat from the fuel assemblies, transferring it to the DSC internal structures and to the outer shell, where it is removed by convection to the air flowing through the module, and by surface-to-surface thermal radiation to the surrounding environment (i.e., the heat shields and inner walls of the concrete module cavity). Neglecting convection in the helium gas within the DSC would tend to result in higher predicted fuel cladding temperatures, since thermal radiation heat transfer would have to 'take up the slack' in removing the decay heat load. Predicted temperatures for the basket components would also be higher, for much the same reason. A general overall effect would be more uniform migration of heat in all directions outward toward the DSC shell, since a major effect of internal convection of the helium gas is to move heat from the lower portion of the horizontal DSC toward to top region. Neglecting convection in the helium gas defines a bounding case that would provide an estimate of the most uniform possible circumferential and axial temperature distributions on the DSC shell, determined only by external 
convection to the air flowing through the module. This would yield the coolest possible axial temperature distribution along the top of the DSC (along with the hottest possible axial temperature distribution on the bottom of the DSC) for a given decay heat load.

Table C. 2 summarizes the peak component temperatures obtained assuming no convection in the helium within the DSC, compared to the results with convection. For consistency, both of these cases were run assuming an ambient air temperature of $82^{\circ} \mathrm{F}\left(28^{\circ} \mathrm{C}\right)$, and with the modifications to model the fine-mesh screens on the inlet and outlet vents. In the calculations assuming no convection within the DSC, the predicted peak DSC shell temperature decreases by $\sim 26$ degrees F (14 degrees C), and the peak fuel temperature increases by about 91 degrees F (50 degrees $\mathrm{C}$ ). This is the expected trend for the bounding assumption of no convection heat transfer within the DSC.

Table C.2. Component Maximum Temperatures for DSC in HSM-1 with and without Convection in Helium

\begin{tabular}{|c|c|c|}
\hline \multirow{2}{*}{ Components } & \multicolumn{2}{|c|}{\begin{tabular}{c} 
HSM-1 Model \\
\cline { 2 - 3 }
\end{tabular}} \\
$\begin{array}{c}\text { with } \\
\left({ }^{\circ} \mathrm{F}\left({ }^{\circ} \mathrm{C}\right)\right)\end{array}$ & $\begin{array}{c}\text { without } \\
\text { convection } \\
\left({ }^{\circ} \mathrm{F}\left({ }^{\circ} \mathrm{C}\right)\right)\end{array}$ \\
\hline Concrete & $133(56)$ & $133(56)$ \\
\hline DSC shell & $204(96)$ & $178(81)$ \\
\hline Fuel & $274(134)$ & $365(185)$ \\
\hline Heat Shield & $140(60)$ & $133(56)$ \\
\hline
\end{tabular}

Table C. 3 compares the results for this bounding case with the measured temperatures from the DSC in HSM-1. The corresponding axial temperature profiles are shown in Figures C. 2 through C.4. For reference, these plots include the temperature profiles obtained assuming appropriate convection in the helium. In Figure C.2, the predicted DSC top surface temperatures are significantly lower without helium convection, compared to the results obtained with convection. This shows that internal convection moves considerable heat from the bottom toward the top within the DSC, as is expected. In Figure C.3, the predicted DSC side surface temperatures are essentially the same, with and without internal convection. This is also as expected, since the side temperatures are dominated by the effects of external air convection. In Figure C.4, the predicted DSC surface temperature profile at the location of the rails is higher without helium convection than with convection. This is also the expected result, since internal convection tends to move heat upward within the DSC, resulting in cooler bottom region temperatures than would be obtained without internal convection. 
Table C.3. HSM-1 Bounding Case with No Helium Convection

\begin{tabular}{|c|c|c|}
\hline & $\begin{array}{c}\text { TC } \\
\text { measurement } \\
\text { in HSM-1 } \\
\left({ }^{\circ} \mathrm{F}\left({ }^{\circ} \mathrm{C}\right)\right)\end{array}$ & $\begin{array}{c}\text { HSM-1 } \\
\text { Model } \\
\text { Temperatures } \\
\left({ }^{\circ} \mathrm{F}\left({ }^{\circ} \mathrm{C}\right)\right)\end{array}$ \\
\hline Temperature Location & $112(44)$ & $109(43)$ \\
\hline Under Grapple Ring & $108(42)$ & $109(43)$ \\
\hline Side $\left(0^{\circ}\right)-0.0$ in. $(0.0 \mathrm{~m})$ & $109(43)$ & $125(52)$ \\
\hline Side $\left(0^{\circ}\right)-20$ in. $(0.51 \mathrm{~m})$ & $108(42)$ & $146(63)$ \\
\hline Side $\left(0^{\circ}\right)-40$ in. $(1.02 \mathrm{~m})$ & $115(46)$ & $111(44)$ \\
\hline Top $\left(90^{\circ}\right)-0.0$ in. $(0.0 \mathrm{~m})$ & $117(47)$ & $136(58)$ \\
\hline Top $\left(90^{\circ}\right)-20$ in. $(0.51 \mathrm{~m})$ & $119(48)$ & $164(73)$ \\
\hline Top $\left(90^{\circ}\right)-40$ in. $(1.02 \mathrm{~m})$ & $104(40)$ & $109(43)$ \\
\hline Side $\left(180^{\circ}\right)-0.0$ in. $(0.0 \mathrm{~m})$ & $105(41)$ & $122(50)$ \\
\hline Side $\left(180^{\circ}\right)-20$ in. $(0.51 \mathrm{~m})$ & $108(42)$ & $141(61)$ \\
\hline Side $\left(180^{\circ}\right)-40$ in. $(1.02 \mathrm{~m})$ & $106(41)$ & $106(41)$ \\
\hline Rail $\left(240^{\circ}\right)-0.0$ in. $(0.0 \mathrm{~m})$ & $107(42)$ & $118(48)$ \\
\hline Rail $\left(240^{\circ}\right)-20$ in. $(0.51 \mathrm{~m})$ & $108(42)$ & $133(56)$ \\
\hline Rail $\left(240^{\circ}\right)-40$ in. $(1.02 \mathrm{~m})$ & $105(41)$ & $106(41)$ \\
\hline Rail $\left(300^{\circ}\right)-0.0$ in. $(0.0 \mathrm{~m})$ & $106(41)$ & $119(48)$ \\
\hline Rail $\left(300^{\circ}\right)-20$ in. $(0.51 \mathrm{~m})$ & $106(41)$ & $134(57)$ \\
\hline Rail $\left(300^{\circ}\right)-40$ in. $(1.02 \mathrm{~m})$ & & \\
\hline
\end{tabular}




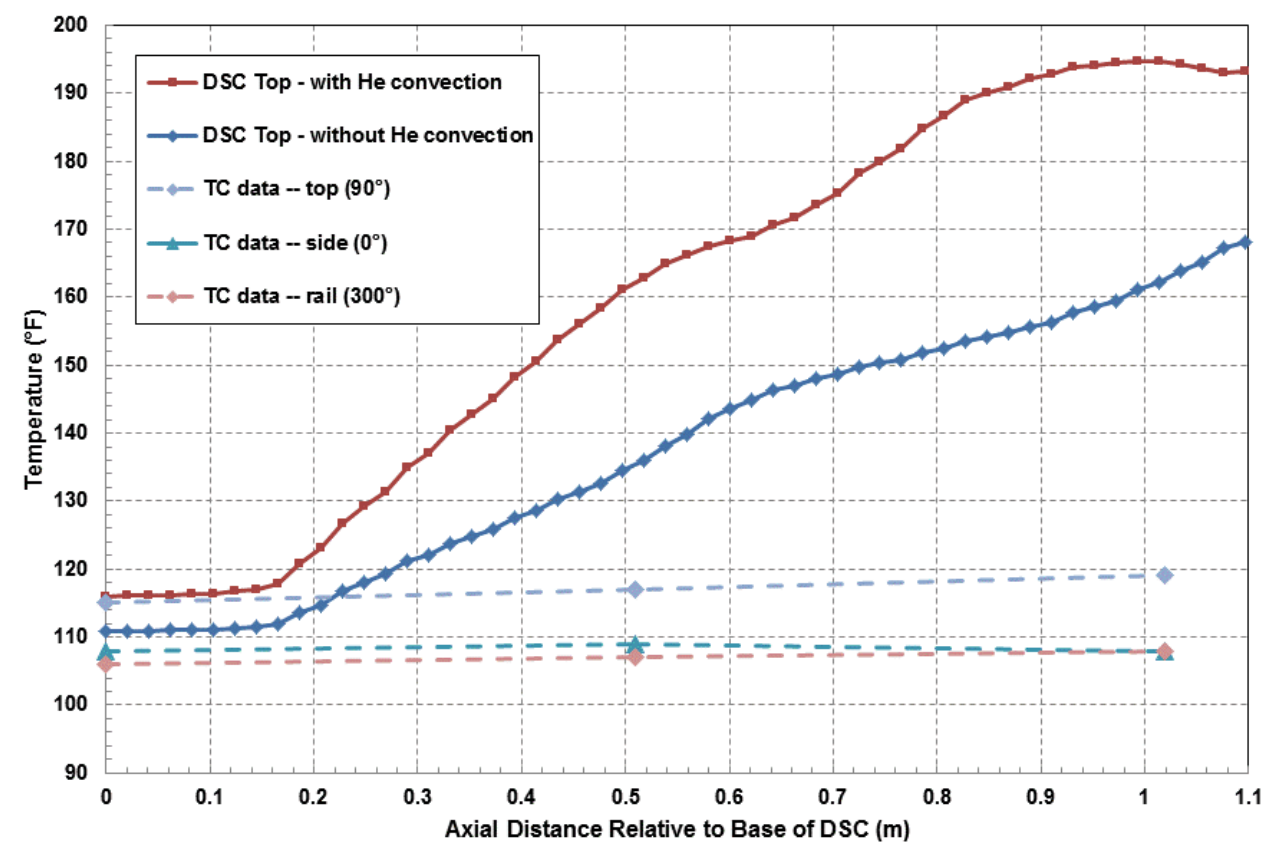

Figure C.2. Axial Temperature Comparison at Top of DSC in HSM-1: with and without Convection in Helium

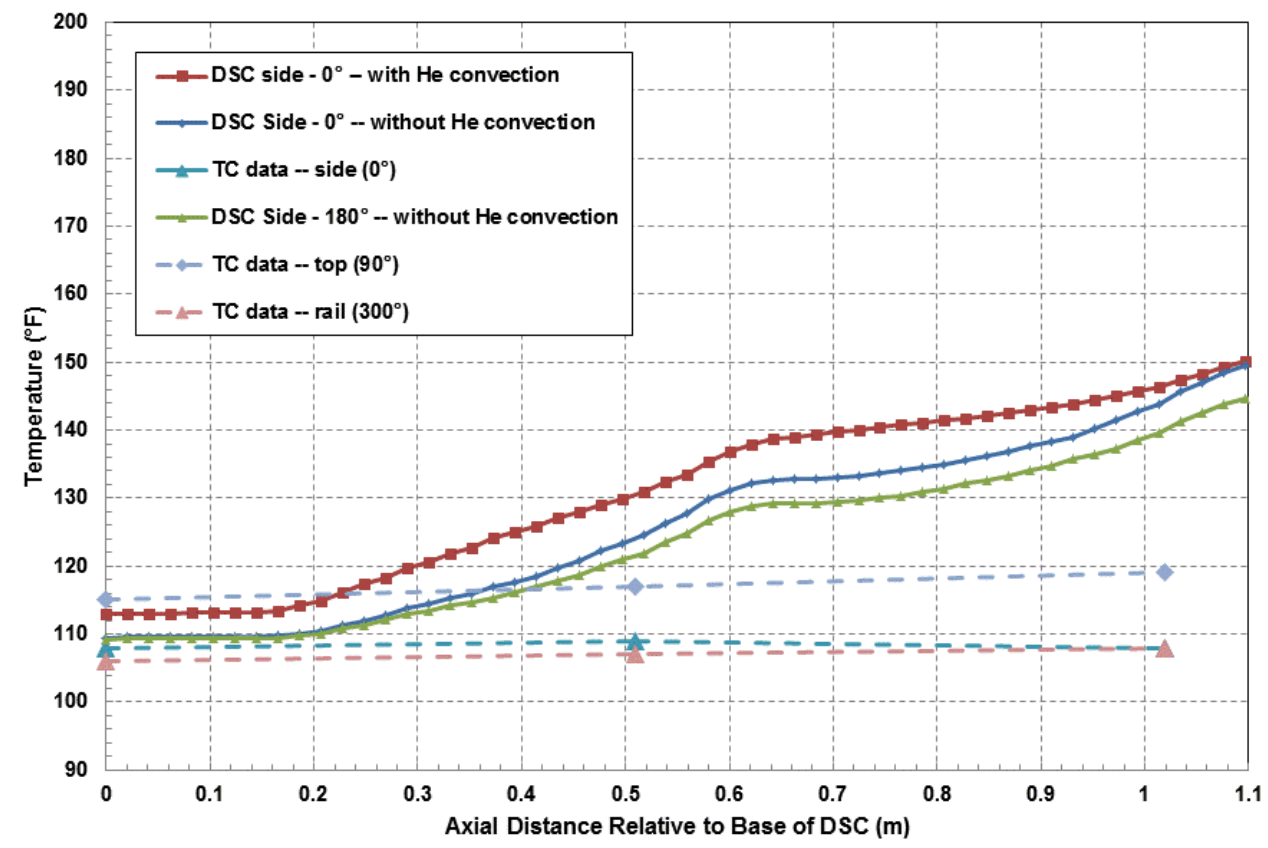

Figure C.3. Axial Temperature Comparison at Sides of DSC in HSM-1: with and without Convection in Helium 


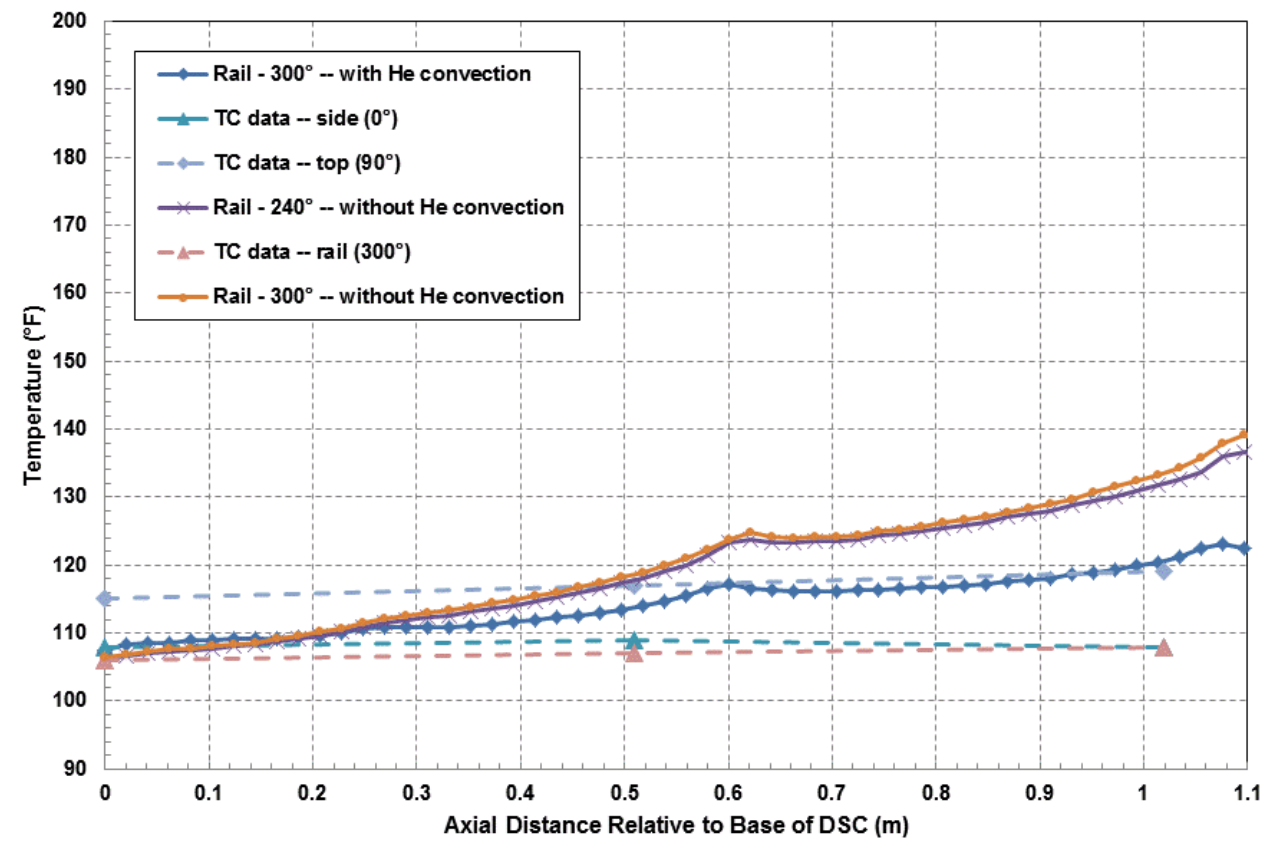

Figure C.4. Axial Temperature Comparison at Support Rail Locations for DSC in HSM-1: with and without Convection in Helium

The differences in the results obtained with and without helium convection within the DSC are physically realistic, and the expected behavior that would result if this mode of heat transfer could in reality be switched "on" and "off" as assumed in the model. However, the axial gradients predicted without helium convection do not significantly improve the comparison with the measured temperature data from the DSC surface in HSM-1. The temperature gradient along the top of the DSC is predicted to be at least an order of magnitude greater than the gradient indicated by the measurements. This would be a very troubling result, if the measured temperatures made any physical sense. A temperature gradient of only 4 degrees-F/m over approximately one quarter of the axial length of the DSC seems highly unlikely, even with the relatively low decay heat load in this DSC. 
Appendix D

\section{Temperature Data}





\section{Appendix D}

\section{Temperature Data}

Contents of e-mail transmittal (July 5, 2012, from John Massari) with temperature measurements for DSCs in HSM-1 and HSM-15.

\begin{tabular}{|l|l|l}
\hline $\begin{array}{l}\text { DSC-11 } \\
\text { HSM-1 }\end{array}$ & Insertion Depth & $\begin{array}{l}\text { DSC-11 } \\
\text { temperature }\left({ }^{\circ} \mathrm{F}\right)\end{array}$ \\
\hline Under Grapple Ring & N/A & 112 \\
\hline 1200 & Full In & 119 \\
\hline 1200 & Half In & 117 \\
\hline 1200 & Bottom Edge & 115 \\
\hline 0300 & Full In & 108 \\
\hline 0300 & Half In & 109 \\
\hline 0300 & Bottom Edge & 108 \\
\hline 0900 & Full In & 108 \\
\hline 0900 & Half In & 105 \\
\hline 0900 & Bottom Edge & 104 \\
\hline 0500 (rail) & Full In & 108 \\
\hline 0500 (raii) & Half In & 107 \\
\hline 0500 (rail) & Eottom Edge & 106 \\
\hline 0700 (rail) & Full In & 106 \\
\hline 0700 (rail) & Half In & 106 \\
\hline 0700 (rail) & Bottom Edge & 105 \\
\hline $\begin{array}{l}\text { DSC-6 } \\
\text { HSM-15 }\end{array}$ & Insertion Depth & DSC-6 \\
\hline Sample Azimuth & & temperature ( ${ }^{\circ} \mathrm{F}$ ) \\
\hline Under Grapple Ring & N/A & 124 \\
\hline & & \\
\hline
\end{tabular}




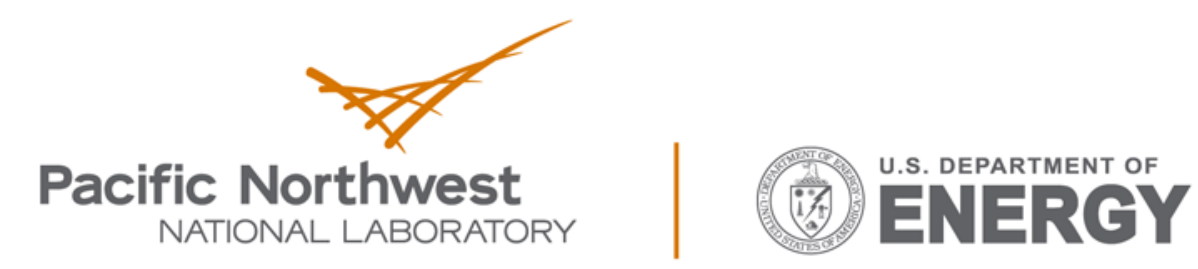

Proudly Operated by Battelle Since 1965

902 Battelle Boulevard

P.O. Box 999

Richland, WA 99352

1-888-375-PNNL (7665)

www.pnnl.gov 